Argonne

Stormwater Management Plan for the Arden Hills Army Training Site, Arden Hills, Minnesota

Environmental Science Division 


\section{About Argonne National Laboratory}

Argonne is a U.S. Department of Energy laboratory managed by UChicago Argonne, LLC

under contract DE-AC02-06CH11357. The Laboratory's main facility is outside Chicago, at 9700 South Cass Avenue, Argonne, Illinois 60439. For information about Argonne

and its pioneering science and technology programs, see www.anl.gov.

\section{DOCUMENT AVAILABILITY}

Online Access: U.S. Department of Energy (DOE) reports produced after 1991 and a growing number of pre-1991 documents are available free via DOE's SciTech Connect (http://www.osti.gov/scitech/)

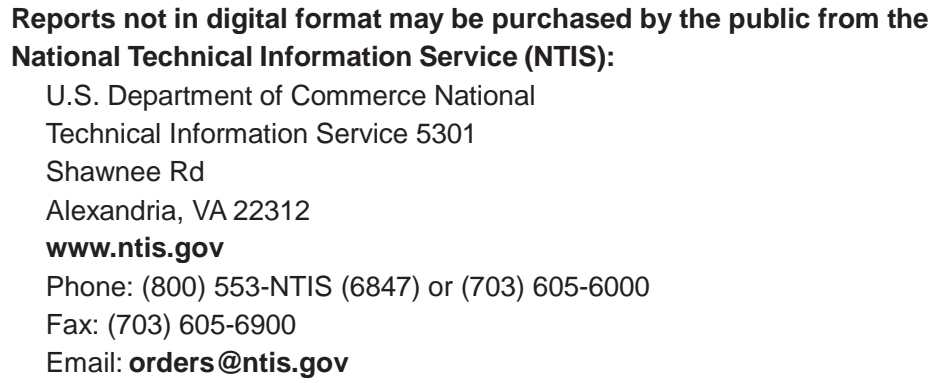

Reports not in digital format are available to DOE and DOE contractors from the Office of Scientific and Technical Information (OSTI):

U.S. Department of Energy

Office of Scientific and Technical Information

P.O. Box 62

Oak Ridge, TN 37831-0062

www.osti.gov

Phone: (865) 576-8401

Fax: (865) 576-5728

Email: reports@osti.gov

\section{Disclaimer}

This report was prepared as an account of work sponsored by an agency of the United States Government. Neither the United States Government nor any agency thereof, nor UChicago Argonne, LLC, nor any of their employees or officers, makes any warranty, express or implied, or assumes any legal liability or responsibility for the accuracy, completeness, or usefulness of any information, apparatus, product, or process disclosed, or represents that its use would not infringe privately owned rights. Reference herein to any specific commercial product, process, or service by trade name, trademark, manufacturer, or otherwise, does not necessarily constitute or imply its endorsement, recommendation, or favoring by the United States Government or any agency thereof. The views and opinions of document authors expressed herein do not necessarily state or reflect those of the United States Government or any agency thereof, Argonne National Laboratory, or UChicago Argonne, LLC. 


\section{Stormwater Management Plan for the Arden Hills Army Training Site, Arden Hills, Minnesota}

Prepared by

A.E. Carr

E.E. Bowen

J.J. Quinn

Environmental Science Division, Argonne National Laboratory

K.K. Wuthrich

A.M. Ziech

Aerotek Inc, staffing office in Chicago, Illinois

Prepared for

Facilities Management Office - Environmental Program,

Department of Military Affairs,

Minnesota Army National Guard

Little Falls, Minnesota

March 2013 



\section{CONTENTS}

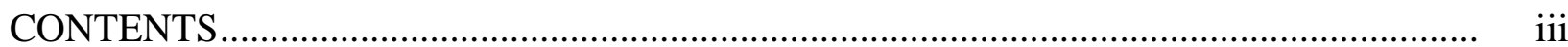

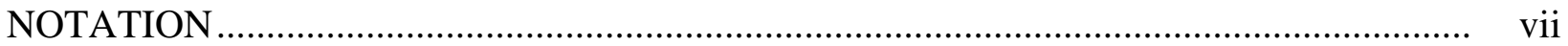

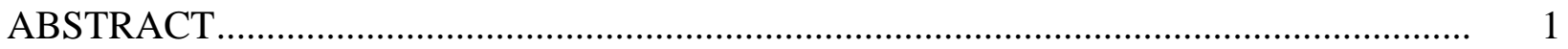

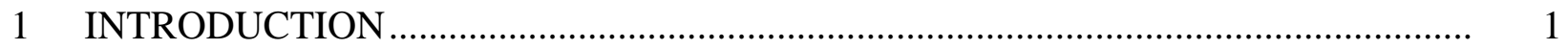

1.1 Overview and Purpose ..................................................................................... 1

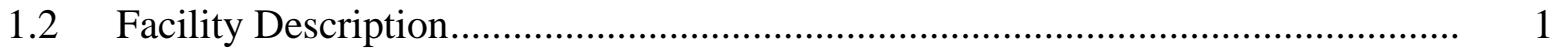

1.3 Environmental Setting ................................................................................................ 2

1.4 Potential Sources of Pollution...................................................................................

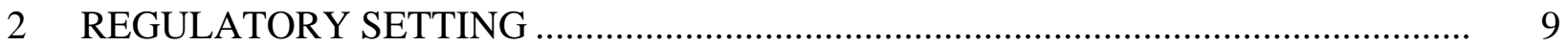

$2.1 \quad$ Federal Regulations ....................................................................................... 9

2.1.1 Clean Water Act................................................................................... 9

2.1.1.1 CWA Section 303 .................................................................... 9

2.1.1.2 CWA Section 404 ................................................................... 10

2.1.1.3 CWA Section 401 .................................................................... 11

2.1.1.4 CWA Section 402 and Municipal Separate Storm Sewer Systems ....................................................................... 12

2.1.2 Safe Drinking Water Act ........................................................................... 13

2.1.3 Energy Independence and Security Act..................................................... 13

2.1.3.1 EISA Section 438.............................................................. 13

2.2 Ramsey County Regulations.................................................................................. 14

2.2.1 Ramsey Conservation District ................................................................ 14

2.2.1.1 RCD and Enforcement of the Wetlands Conservation Act ......... 14

$2.3 \quad$ Rice Creek Watershed District Regulations ............................................................ 15

2.3.1 RCWD General Rules...................................................................... 15

2.3.2 2010 RCWD Watershed Management Plan .............................................. 15

2.3.3 RCWD Permitting for Development ......................................................... 16

$2.4 \quad$ City of Arden Hills Requirements ...................................................................... 16

2.4.1 City of Arden Hills MS4 Permit and SWPPP.......................................... 16

2.5 Construction Stormwater Permit............................................................................. 17

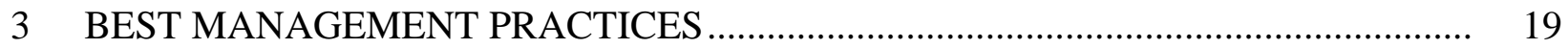

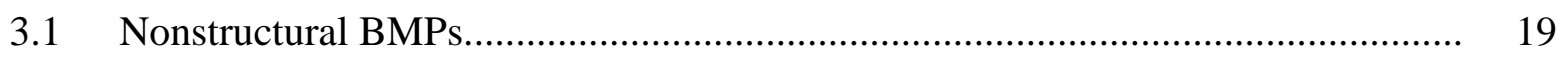

3.1.1 Pollution Prevention Practices ................................................................... 19

3.1.2 Improved Site Design ............................................................................ 20

3.1.3 Runoff Volume Minimization.................................................................... 21

3.1.4 Construction Sediment Control.............................................................. 21 


\section{CONTENTS (Cont.)}

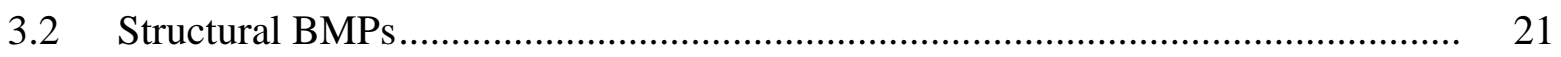

3.2.1 Bioretention..................................................................................... 21

3.2.2 Filtration............................................................................... 22

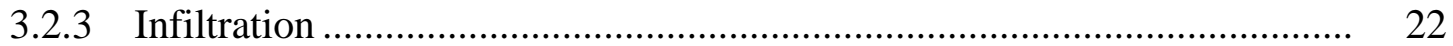

3.2.4 Stormwater Ponds .................................................................................. 22

3.2.5 Constructed Wetlands ........................................................................... 23

3.3 EPA Technical Guidance on Implementing EISA Section 438............................... 23

3.4 State of Minnesota Construction Guidelines ......................................................... 24

3.5 Metropolitan Council Stormwater Guidance ........................................................ 24

3.5.1 Metropolitan Area Master Water Supply Plan............................................. 24

3.5.2 Water Resources Management Policy Plan ................................................. 25

3.5.3 BMPs of Urban Small Sites ................................................................... 26

3.6 Rice Creek Watershed District Stormwater BMPs ................................................. 27

4 WATERSHED MODELING ……………………................................................... 29

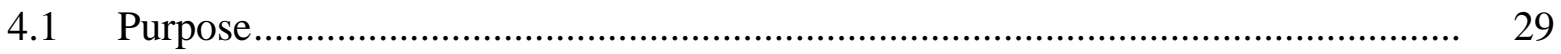

4.2 Approach for Simulating the Stormwater Runoff................................................. 31

4.2.1 Model Selection .................................................................................... 31

4.2.2 Watershed Delineation...................................................................... 31

4.3 Approach for Estimating Stormwater Runoff ....................................................... 38

4.3.1 Curve Number............................................................................... 38

4.3.2 Time of Concentration .............................................................................. 43

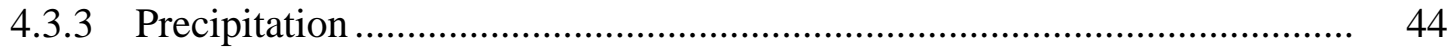

4.3.4 Method Calculations .......................................................................... 44

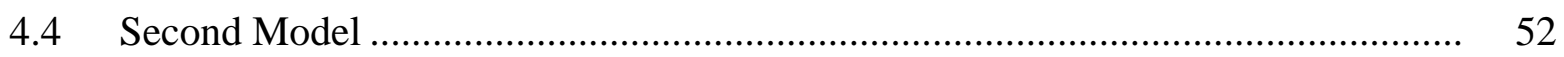

4.4.1 Watersheds upon Completion of the FMS Site.......................................... 52

4.4.2 Approach for Simulating Stormwater upon Completion of the

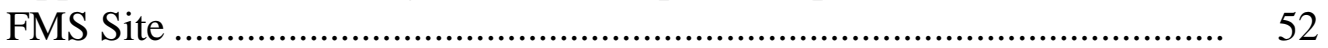

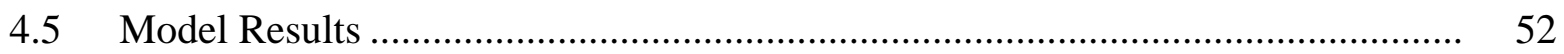

4.5.1 Detention Ponds .................................................................................. 54

4.5.2 Model Comparisons ............................................................................... 55

4.6 Spring Snowmelt Event ................................................................................. 59

4.7 Runoff Water Quality Volumes .................................................................... 59

4.7.1 Rainfall ...................................................................................... 59

4.7.2 Snowmelt ................................................................................... 60

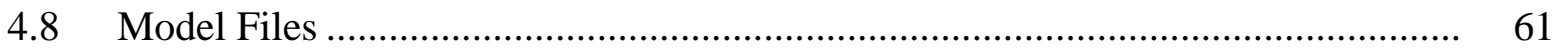

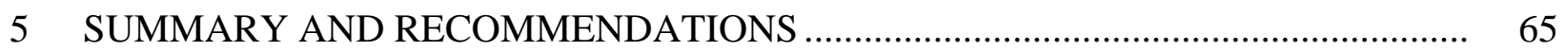

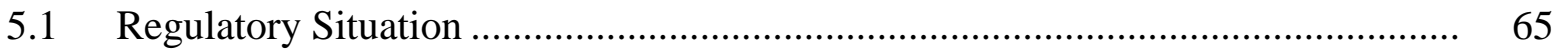

5.2 Best Management Practice Recommendations ........................................................ 65

5.2.1 Inspections, Operations, and Maintenance ……………………………..... 65 
5.2.2 Record Keeping ..................................................................................... 66

5.2.3 Key BMPs Recommended for AHATS ................................................... 66

5.3 Model Summary and Application......................................................................... 68

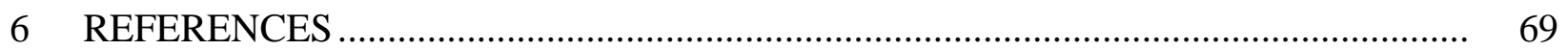

\section{APPENDICES}

APPENDIX A: Model Parameters and Outputs for All Subbasins

by Using the TR-55 Graphical Peak Discharge Method .............................. 73

APPENDIX B: Flow at Subbasins for Storm Events using the TR-55 Tabular

Hydrograph Method................................................................................... 97

\section{FIGURES}

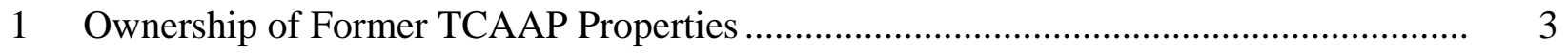

2 Disposal Areas of the Former TCAAP................................................................................ 6

3 Cantonment Area's AHRC and FMS and Surroundings................................................ 30

$4 \quad$ Topographic Contours of the AHATS Property.................................................................... 33

$5 \quad$ Basins and Outlet Points in the Study Area before Phase 1 Construction ......................... 34

$6 \quad$ Basins and Outlet Points in the Study Area after Phase 1 Construction ............................. 35

7 Example of a Flow Accumulation Path That Needed To Be Manually Modified Because of Existing Stormwater Structures .......................................................................... 36

$8 \quad$ Road and Culvert Locations ............................................................................................ 37

$9 \quad$ Soils in the AHATS Drainage Areas.............................................................................. 39

10 Land Use Categories for the AHATS Drainage Areas...................................................... 41 


\section{TABLES}

1 Disposal Areas at TCAAP and Associated Histories, Activities, and Potential

Contaminants, 1942-1981

2 Summary of SWPPP BMPs Used To Meet the Minimum Control Measures of the Arden Hills SWPPP ..................................................................................... 18

3 Hydrologic Soil Group Characteristics ……………..................................................... 40

4 Curve Numbers Used in TR-55 for Different Land Use Types and Hydrologic

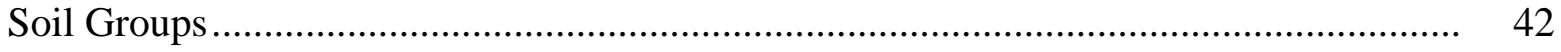

$5 \quad$ Manning’s n Roughness Coefficients........................................................................... 45

6 Estimated Ramsey County Rainfall Depths for a 24-Hour Storm Duration for Different Storm Recurrence Intervals ................................................................................... 45

7 Comparison of Minnesota Stormwater Manual and Rice Creek Watershed District Criteria

8 Proportion of Pond and Swamp Area in Each Basin........................................................ 51

$9 \quad$ Runoff Rates for FMS Bioretention and Detention Pond ………….................................. 55

10 Pre-Phase 1 Runoff Rates and Volumes as Calculated by TR-55 Tabular Hydrograph Discharge Method .................................................................................... 57

11 Post-FMS Runoff Rates and Volumes as Calculated by TR-55 Tabular Hydrograph Discharge Method ......................................................................................... 58

12 Calculated Runoff from the 100-Year, 10-Day Snowmelt Event upon Completion of FMS

13 Calculated Water Quality Runoff Volumes upon Completion of FMS 


\section{NOTATION}

\section{ACRONYMS AND ABBREVIATIONS}

$\begin{array}{ll}\text { AHATS } & \text { Arden Hills Army Training Site } \\ \text { AHRC } & \text { Arden Hills Readiness Center } \\ \text { amsl } & \text { above mean sea level } \\ \text { B3 } & \text { Buildings, Benchmarks and Beyond (Project) } \\ \text { BMP } & \text { best management practice } \\ \text { BWSR } & \text { Board of Water and Soil Resources (Minnesota) } \\ \text { CN } & \text { curve number } \\ \text { COC } & \text { chemical of concern } \\ \text { the Corps } & \text { U.S. Army Corps of Engineers } \\ \text { the Council } & \text { Metropolitan Council (Twin Cities) } \\ \text { CWA } & \text { Clean Water Act } \\ \text { DEM } & \text { digital elevation model } \\ \text { DNR } & \text { Department of Natural Resources (Minnesota) } \\ \text { DOD } & \text { U.S. Department of Defense } \\ \text { EISA } & \text { Energy Independence and Security Act } \\ \text { E.O. } & \text { Executive Order } \\ \text { EPA } & \text { U.S. Environmental Protection Agency } \\ \text { FMS } & \text { Field Maintenance Shop } \\ \text { GIS } & \text { geographic information system } \\ \text { HSG } & \text { Hydrologic Soil Group } \\ \text { HVAC } & \text { heating, ventilation, and air-conditioning } \\ \text { LIDAR } & \text { light detection and ranging } \\ \text { METF } & \text { maximum extent technically feasible } \\ \text { MNARNG } & \text { Minnesota Army National Guard } \\ \text { MPCA } & \text { Minnesota Pollution Control Agency } \\ \text { MS4 } & \text { Municipal Separate Storm Sewer System } \\ \text { NLCD } & \text { National Land Cover Database } \\ \text { NPDES } & \text { National Pollutant Discharge Elimination System } \\ \text { NRCS } & \text { Natural Resources Conservation Service (formerly SCS) } \\ \text { ORVW } & \text { Outstanding Resource Value Water } \\ \text { PCB } & \text { polychlorinated biphenyl } \\ \text { PSH } & \text { principal spillway hydrograph } \\ \text { P.L. } & \text { Public Law } \\ \text { Q1 } & \text { 1-day volume runoff } \\ \text { Q10 } & \text { 10-day volume runoff } \\ \text { RCD } & \text { Ramsey Conservation District } \\ \text { RCWD } & \text { Rice Creek Watershed District } \\ \text { SCS } & \text { Soil Conservation Service } \\ \text { SDWA } & \text { Safe Drinking Water Act } \\ \text { SSURGO } & \text { Soil Survey Geographic Database (NRCS) } \\ \text { SWMP } & \text { Stormwater Management Plan } \\ & \end{array}$




$\begin{array}{ll}\text { SWPPP } & \text { Stormwater Pollution Prevention Plan } \\ \text { SVOC } & \text { semivolatile organic compound } \\ \text { TCAAP } & \text { Twin Cities Army Ammunition Plant } \\ \text { TMDL } & \text { total maximum daily load } \\ \text { TP-40 } & \text { Technical Paper 40 } \\ \text { TR-55 } & \text { Technical Release } 55 \\ \text { UA } & \text { urbanized area } \\ \text { USACHPPM } & \text { U.S. Army Center for Health Promotion and Preventive Medicine } \\ \text { U.S.C. } & \text { United States Code } \\ \text { USFWS } & \text { U.S. Fish and Wildlife Service } \\ \text { VOC } & \text { volatile organic compound } \\ \text { WCA } & \text { Wetlands Conservation Act } \\ \text { WMP } & \text { Watershed Management Plan (RCWD) } \\ \text { WMS } & \text { Watershed Modeling System }\end{array}$

\section{UNITS OF MEASURE}

$\begin{array}{ll}\text { acre-ft } & \text { acre-foot (feet) } \\ \mathrm{cfs} & \text { cubic foot (feet) per second } \\ { }^{\circ} \mathrm{F} & \text { degree(s) Fahrenheit } \\ \mathrm{ft} & \text { foot (feet) } \\ \mathrm{ft}^{2} & \text { square foot (feet) } \\ \mathrm{ft}^{3} & \text { cubic foot (feet) } \\ \mathrm{h} & \text { hour(s) } \\ \mathrm{hr} & \text { hour(s) } \\ \mathrm{in} . & \text { inch(es) } \\ \mathrm{m} & \text { meter(s) } \\ \mathrm{mi} & \text { mile(s) } \\ \mathrm{mi} & \text { square mile(s) } \\ \mathrm{min} & \text { minute(s) } \\ \mathrm{s} & \text { second(s) }\end{array}$




\title{
STORMWATER MANAGEMENT PLAN FOR THE ARDEN HILLS ARMY TRAINING SITE, ARDEN HILLS, MINNESOTA
}

by

\author{
A.E. Carr, K.K. Wuthrich, A.M. Ziech, E.E. Bowen, and J.J. Quinn
}

\begin{abstract}
This stormwater management plan focuses on the cantonment and training areas of the Arden Hills Army Training Site (AHATS). The plan relates the site stormwater to the regulatory framework, and it summarizes best management practices to aide site managers in promoting clean site runoff. It includes documentation for a newly developed, detailed model of stormwater flow retention for the entire AHATS property and adjacent upgradient areas. The model relies on established modeling codes integrated in a U.S. Department of Defense-sponsored software tool, the Watershed Modeling System (WMS), and it can be updated with data on changes in land use or with monitoring data.
\end{abstract}

\section{INTRODUCTION}

\subsection{OVERVIEW AND PURPOSE}

The Arden Hills Army Training Site (AHATS) is located in Arden Hills, Minnesota, in the northern suburbs of the Twin Cities metropolitan area. It was formerly known as the Twin Cities Army Ammunition Plant (TCAAP) and was initially used for producing small arms ammunition in World War II. TCAAP, which consisted of more than 2,300 acres, has been divided into several properties; the largest is the AHATS for use by the Minnesota Army National Guard (EPA 2012c).

This Stormwater Management Plan (SWMP) focuses on an assessment of stormwater drainage and management issues associated with the AHATS property. It is intended to be a living document that can be updated in the future as additional site information becomes available. Examples of such information would be new information on proposed or final developments involving new construction and surface water monitoring data. In particular, the watershed model created as part of this SWMP can be modified to account for changes in land use or refined if calibration data are collected.

\subsection{FACILITY DESCRIPTION}

The AHATS property consists of a cantonment area and a training area. The cantonment consists of the completed Arden Hills Readiness Center (AHRC) and a nearly completed Field 
Maintenance Shop (FMS). Other facilities are in planning phases (Julie Snow Architects 2011). The large training area includes open land, gravel or paved roads, remnant TCAAP buildings, and two lakes.

The original TCAAP site included more than 2,300 acres of land. The bulk of the property is now AHATS. However, more than 700 acres have been declared in excess by the Army, including 113 acres along Rice Creek for a county park system and 49 acres for a wildlife corridor (Figure 1). The purpose of the wildlife corridor is to connect Rice Creek to a future regional park (the current AHATS) (Global Security 2012). Smaller portions have been transferred to Ramsey County for a public works facility, to the City of Arden Hills for a new city hall, and to the U.S. Army Reserve. As a result of the property transfers, the land owners currently surrounding AHATS are the Arden Hills city office, the Ramsey County facilities, the U.S. Army Reserve, and the city of Arden Hills to the south; the city of Shoreview to the north and east; and Army property and the city of New Brighton to the west.

\subsection{ENVIRONMENTAL SETTING}

AHATS is dominated topographically by the Arsenal Kame, located near the center of the property. Marsden Lake is located in the eastern portion of AHATS. Rice Creek, part of the original TCAAP property, is northwest of the AHATS boundary. Elevations in the vicinity range from $880 \mathrm{ft}$ above mean sea level (amsl) along Rice Creek to 1,100 ft amsl on the kame.

The site geology consists of Pleistocene glacial deposits over Paleozoic bedrock. The glacial deposits and the resulting topography are largely the result of two ice advances in lateWisconsinan time: the Superior lobe and the Grantsburg sublobe (Wright 1972). The Superior lobe originated from the northeast and deposited a reddish, coarse-grained glacial till and associated outwash deposits. Tunnel valleys developed beneath the Superior ice, conveying basal meltwater and sediment under high pressure toward the ice margin (Wright 1973). Patterson (1994), Meyer et al. (1993), and Quinn (1998) describe large ice-contact fans at the mouths of many tunnel valleys in east-central Minnesota. These fans represent periodic stable locations of the Superior lobe during development of the terminal and recessional moraines. The fans dominate the local topography and are especially high when compared to the levels of the tunnel valleys. The height of the fans is attributed to the high hydraulic head of the sedimenttransporting meltwater of the tunnel valleys (Patterson 1994).

The main topographic feature of AHATS - Arsenal Kame - is an example of a tunnel valley fan (Patterson 1994). It is composed mainly of sand and gravel, along with thin, discontinuous deposits of Superior lobe till. Later its edges were modified by meltwater, and it was partially mantled with Grantsburg sublobe deposits. The Grantsburg sublobe was a topographically influenced portion of a larger lobe, the Des Moines lobe, which advanced from

northwestern Minnesota into central Iowa. In the Twin Cities region, the Grantsburg traveled in a northeasterly direction, over the younger Superior lobe deposits. The Grantsburg till is finegrained and gray (unoxidized) or buff (oxidized) in color. 


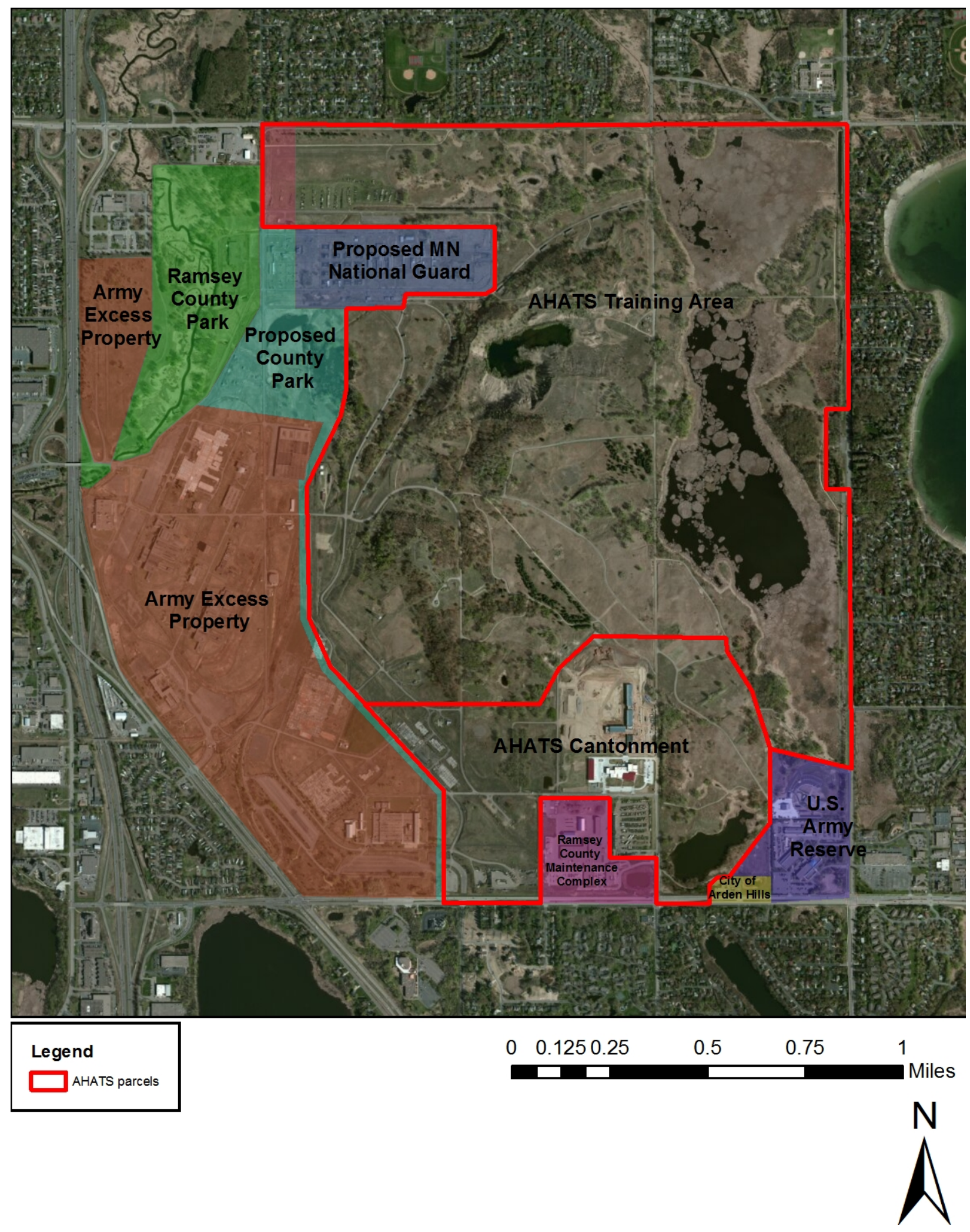

FIGURE 1 Ownership of Former TCAAP Properties (Source: based on Metropolitan Council 2011) 
Stone (1966) mapped the surficial geologic deposits at AHATS. The Arsenal Kame consists of medium to coarse sand and gravel. Areas west, north, and east of the kame are fine lacustrine sand. In the southern part of AHATS, the surface is Grantsburg sublobe till, locally mixed with reddish brown Superior lobe till or with sand and gravel.

Climate data summarized by Argonne (1991) include an average annual temperature of $44^{\circ} \mathrm{F}$; a historical daily temperature range of -34 to $108^{\circ} \mathrm{F}$; average daily minimum temperatures that are generally below freezing from November through March; annual precipitation of $25 \mathrm{in}$., with June and July having the highest precipitation; an average annual snowfall of approximately 40 in.; and prevailing winds that are northeasterly from November through April and southsouthwesterly from May through October.

\subsection{POTENTIAL SOURCES OF POLLUTION}

Argonne National Laboratory (Argonne) performed the preliminary assessment and remedial investigation at TCAAP and identified 14 disposal sites functioning as contaminant source areas (Argonne 1988, 1991). These include Sites A, B, C, D, E, F, G, H, I, J, K, 129-3, 129-5, and 129-15 (Figure 2, Table 1). Contaminants of concern included volatile organic compounds (VOCs), semivolatile organic compounds (SVOCs), polychlorinated biphenyls (PCBs), explosives, pesticides, metals, propellants, oil, dioxin, cyanide, and radionuclides. Sites A, D, G, H, and 129-15 were used as dumps, and several ranges were impacted by lead from ammunition and grenade testing (EPA 2012c).

Various remedial actions took place or are continuing to take place to address groundwater and soil contamination at the site (EPA 2012c). For groundwater, the remedial actions have included on-site pump-and-treat systems and off-site municipal water treatment. For soil, actions have included thermal treatment for PCBs; excavation/stabilization/off-site disposal of soil from Sites A, C, E, H, 129-3, 129-5, the grenade range, the outdoor firing range, and the 150 reservoir site; the operation of a soil vapor extraction system for deep soils at Sites D and G; soil vapor extraction/air sparging at Site A; characterization of dumps; and the placement of cover at Sites C, G, and 129-15. TCAAP sewer lines were remediated as of 1986.

The potential for TCAAP-related contaminants to appear in stormwater runoff is based on the status of individual sites. Those sites that have a cover placed above residual contamination may be subject to state permit requirements, including periodic inspections of cover integrity. The U.S. Army Center for Health Promotion and Preventive Medicine (USACHPPM 2004) conducted ecological risk assessments at aquatic sites at the facility and summarized data on relevant potentially contaminated soil. Soils at the grenade range at the north end of Marsden Lake and the outdoor firing range at the south end of the lake were remediated to an industrial land use standard in 1999. Runoff may have transported contaminants from these sources to Marsden Lake. USACHPPM notes that chemicals of concern (COCs) in the lake's surface water include metals (aluminum, barium, lead, manganese, mercury, zinc), and that COCs in the sediment include metals (aluminum, antimony, arsenic, cadmium, lead, vanadium) and SVOCs. Pond G is a small pond near Site G (an uncontrolled landfill) that may have received runoff from Site G and/or Site F (a former burning area). USACHPPM identified 
13 inorganics as COCs in the surface water, and it identified pesticides, PCBs, and SVOCs as COCs in the sediment. Site H-1, along Sunfish Lake, was an unpermitted landfill. USACHPPM notes that contaminated soil may have been transported as runoff to the lake. The soil was remediated in 1999-2001 because of its arsenic, antimony, copper, lead, and manganese. COCs at Sunfish Lake identified by USACHPPM included cadmium, mercury, and zinc in the surface water and aluminum, chromium, lead, vanadium, and zinc in the sediment. 

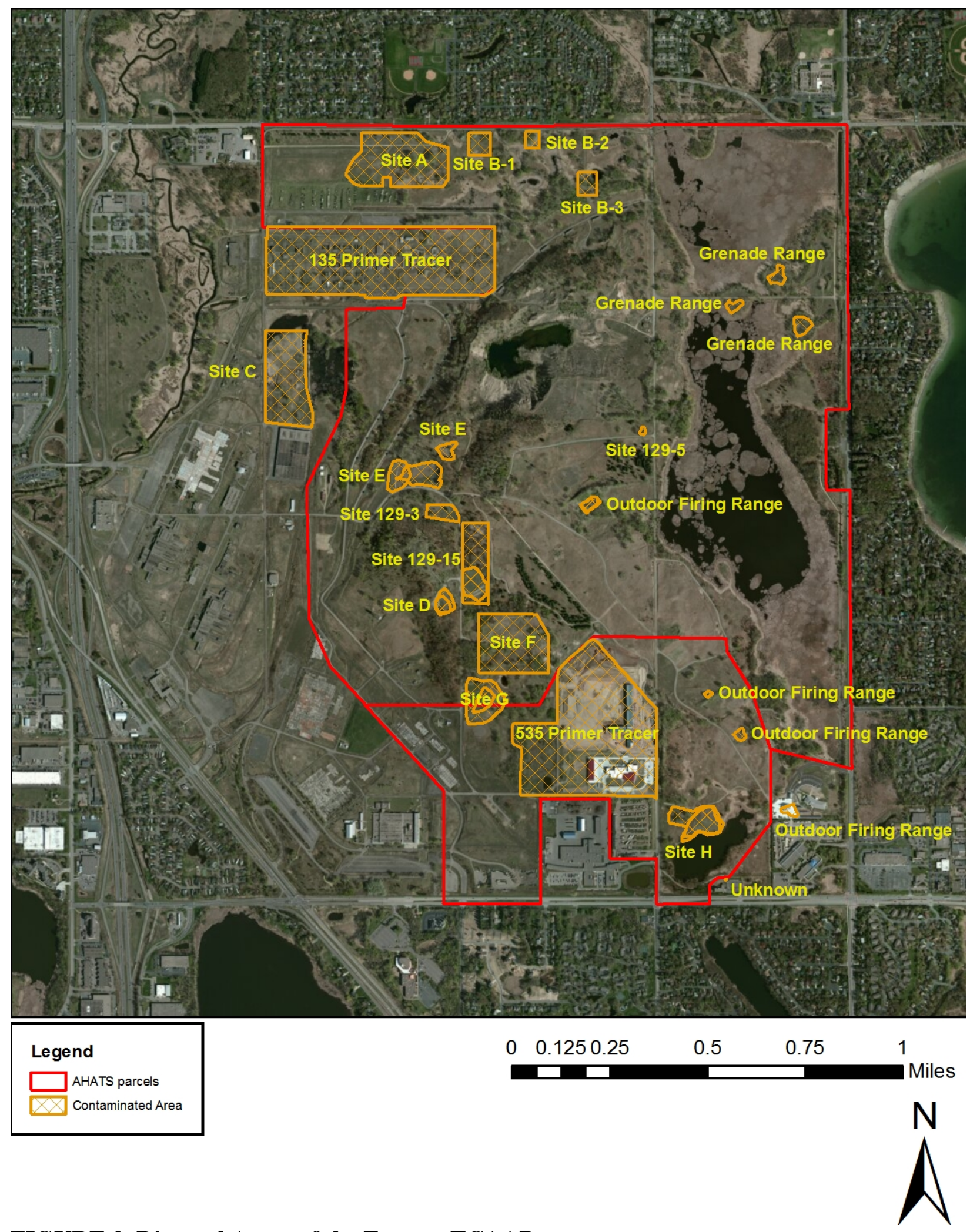

FIGURE 2 Disposal Areas of the Former TCAAP 


\section{TABLE 1 Disposal Areas at TCAAP and Associated Histories, Activities, and Potential Contaminants, 1942-1981}

\begin{tabular}{|c|c|c|c|c|}
\hline Site $^{\mathrm{a}}$ & Name or Synonym & Period Used ${ }^{\mathrm{b}}$ & Disposal Activity & Potential Contaminants \\
\hline A & - & 1942-1962 & $\begin{array}{l}\text { Burning of explosive wastes; burial of mercury crack cases; } \\
\text { dumping of sewage sludge }\end{array}$ & Mercury, sludge contaminants \\
\hline B & - & - & No documentation of disposal at Site B was found. & Unknown \\
\hline \multirow[t]{2}{*}{$\mathrm{C}$} & 120 area, 640 area & 1947-1966 & Burning of lumber, solvents, oils, contaminated maizo & Solvents, oils, unknown chemicals \\
\hline & & 1945-1981 & Open storage & \\
\hline $\mathrm{D}$ & 326 burning area & 1950-1973 & $\begin{array}{l}\text { Burning of sump powder wastes, scrap propellant powder, } \\
\text { solvents, thinners, oils, rags, chemicals; dumping of } \\
\text { neutralized cyanide wastes; leaching of chemicals }\end{array}$ & $\begin{array}{l}\text { Solvents, thinners, oils, cyanide, } \\
\text { unknown chemicals }\end{array}$ \\
\hline $\mathrm{E}$ & 670 area & 1942-1949 & $\begin{array}{l}\text { Burning of ammunition boxes, unknown materials; dumping of } \\
\text { debris, trash; burial of debris, trash }\end{array}$ & Unknown \\
\hline $\mathrm{F}$ & 326 burning area & 1950-1978 & $\begin{array}{l}\text { Burning of scrap explosives; burial of mercury crack cases, } \\
\text { dumping of cyanide pots }\end{array}$ & Mercury, cyanide \\
\hline G & Snelling dump & $<1945-1976$ & $\begin{array}{l}\text { Dumping of metal shavings, cleaning materials; burial of } \\
\text { concrete, asphalt }\end{array}$ & Metals, unknown chemicals \\
\hline $\mathrm{H}$ & $\begin{array}{l}5002 \text { burning cage, } \\
949 \text { burning cage, } \\
\text { Hamline Avenue dump }\end{array}$ & 1943-1967 & $\begin{array}{l}\text { Burning of paper, rubbish, contaminated maizo, scrap wood; } \\
\text { dumping of industrial sludge, ashes, solvent }\end{array}$ & Unknown chemicals \\
\hline $129-3$ & - & 1971-1976 & $\begin{array}{l}\text { Burning of scrap powder; leaching of lead styphnate wastes, } \\
\text { wastewaters }\end{array}$ & Lead, unknown chemicals \\
\hline $129-5$ & - & 1948-1951 & Burning of scrap explosives, bullets, solvents & Solvents, lead \\
\hline $129-15$ & - & $1970-1981$ & Dumping of construction wastes; burial of construction wastes & Unknown \\
\hline
\end{tabular}


TABLE 1 (Cont.)

\begin{tabular}{|c|c|c|c|c|}
\hline Site $^{\mathrm{a}}$ & Name or Synonym & Period Used ${ }^{\mathrm{b}}$ & Disposal Activity & Potential Contaminants \\
\hline $\mathrm{J}$ & $\begin{array}{l}\text { Portion of sanitary and } \\
\text { storm sewer }\end{array}$ & 1942-1981 & $\begin{array}{l}\text { Sewer disposal of process wastes, oil and grease, heavy metals, } \\
\text { solvents, explosives, lacquers, thinners, metal shavings, acids }\end{array}$ & $\begin{array}{l}\text { Oil and grease, metals, heavy } \\
\text { metals, degreasing wastes, } \\
\text { solvents, cyanide, lacquers, } \\
\text { thinners, unknown chemicals }\end{array}$ \\
\hline I & Building 502 & 1942-1981 & $\begin{array}{l}\text { Sewer disposal of oil and grease, metal grindings, heavy } \\
\text { metals, solvents, degreasing wastes, cyanide; storage of } \\
\text { chemicals }\end{array}$ & $\begin{array}{l}\text { Oil and grease, metals, heavy } \\
\text { metals, solvents, unknown } \\
\text { chemicals }\end{array}$ \\
\hline K & Building 103 & 1942-1981 & $\begin{array}{l}\text { Sewer disposal of process wastes, oil and grease, cyanide, } \\
\text { solvents, heavy metals, degreasing wastes }\end{array}$ & $\begin{array}{l}\text { Oil and grease, heavy metals, } \\
\text { solvents, degreasing wastes, } \\
\text { cyanide, unknown chemicals }\end{array}$ \\
\hline
\end{tabular}

a See Figure 2 for locations.

b Information is included only when original documentation exists or when the information is otherwise confirmable.

Source: Argonne (1988) 


\section{REGULATORY SETTING}

\subsection{FEDERAL REGULATIONS}

This chapter summarizes regulatory information relevant to AHATS stormwater from the federal to the local levels. State-level regulations are discussed, as appropriate, as they relate to various federal and local regulations.

\subsubsection{Clean Water Act (CWA)}

The CWA (33 U.S.C. $\$ 1251$ et seq. in the United States Code) is the primary federal legislation regulating water pollution in the United States. Passed in 1972 (and further amended in 1977 and 1987), the goal of the CWA is to restore the physical, chemical, and biological integrity of the nation's waters by eliminating water pollution (CWA 1972). The CWA requires parties that wish to discharge pollutants into surface waters of the United States to obtain a permit under the National Pollutant Discharge Elimination System (NPDES). NPDES permits, authorized by CWA Section 402, primarily address point source discharges, such as outfalls from a municipal facility, and mandate that the effluent contain a limited amount of pollutants. Effluent limits are based on wastewater treatment technology. Additional regulations under the CWA apply to discharges of stormwater runoff, as described below.

\subsubsection{CWA Section 303}

The CWA requires states to adopt water quality standards to protect lakes, streams, and wetlands from pollution. The standards define how much of a pollutant (bacteria, mercury, sediment, etc.) can be in a body of water while still allowing its designated uses (e.g., for drinking water, fishing, swimming) to be met. CWA Section 303(d) requires states to identify and list surface waters within their boundaries for which water quality objectives are not being achieved or maintained. A water body is said to be impaired if its levels of contamination exceed the levels established in the water quality standards. Each state is required to establish a priority ranking for such waters, taking into account the severity of the pollution and the beneficial uses to be made of the waters. Biennially (during even-numbered years), each state must submit its Impaired Waters List (i.e., 303(d) List) to the U.S. Environmental Protection Agency (EPA) for federal approval.

For the surface water bodies identified and prioritized as described above, Section 303(d) also requires each state to establish total maximum daily loads (TMDLs) for those pollutants. A TMDL is a numeric target for the amount of a pollutant that, when achieved, will result in the attainment of water quality standards. TMDLs also set limits and reduction goals for restoring impaired waters so they meet standards. The Impaired Waters List includes those waters needing a TMDL plan and those for which plans have already been developed and approved by the EPA. 
The Minnesota Pollution Control Agency (MPCA) is responsible for the assessment and listing process for Minnesota's surface waters, according to Chapter 115 of the Minnesota Statutes. The MPCA monitors and assesses water quality, lists impaired waters, and develops TMDLs. The 303(d) Lists are submitted to the public for comment. Changes may be made to the 303(d) List and TMDLs on the basis of feedback received during the public involvement period. A final draft is then submitted to the EPA for approval. Once this 303(d) List is approved, it becomes the state's Impaired Waters List for the next two years.

The MPCA has developed a 10-year schedule for monitoring and assessing each of Minnesota’s 81 major watersheds. Minnesota’s Draft 2012 303(d) List (MPCA 2012a) contains 2,171 impairments requiring TMDL studies; 511 of those impairments are proposed new listings. The current inventory of all impaired waters now totals 3,638 impairments, which include impairments in need of TMDLs, those with completed TMDLs not yet restored, and impairments due to natural sources. The Draft 2012 303(d) List has been submitted to the public for a public comment period. The MPCA is reviewing comments and will develop a response document before submitting the Final 303(d) List to the EPA.

Rice Creek runs through the northwest corner of the AHATS facility and is listed as impaired for aquatic life on the Draft 2012 303(d) List (MPCA 2012a). A biologically impaired stream or wetland must be restored to a specific assemblage of fish, macroinvertebrates, or plants through the TMDL process. Rice Creek has a scheduled TMDL start date of 2012 and a scheduled TMDL completion date of 2015, according to Minnesota's 2012 Draft TMDL List. Since the TMDL represents a quantity of a pollutant, a surrogate chemical must be found for the biological impairment, and the TMDL will be written in terms of the surrogate chemical. A TMDL may be estimated from several sources (e.g., agriculture, stormwater, and wastewater treatment plants), and a portion of the TMDL may be regulated under Municipal Separate Storm Sewer System (MS4) NPDES permits, discussed in Section 2.1.1.4, under the description of Section 402 of the CWA.

\subsubsection{CWA Section 404}

Section 404 of the CWA establishes a program to regulate the discharge of dredged or fill material into waters of the United States (i.e., relatively permanent, standing or continuously flowing bodies of water "forming geographic features" that are described in ordinary parlance as "streams[,] ... oceans, rivers, [and] lakes."), including wetlands. Activities regulated under this

program include filling for development, and a Section 404 permit is required before dredged or fill material may be discharged into waters of the United States. No discharge of dredged or fill material may be permitted (1) if a practicable alternative exists that is less damaging to the aquatic environment or (2) if the nation's waters would be significantly degraded. Parties applying for a permit must show that they have (1) taken steps to avoid wetland impacts, (2) minimized potential impacts on wetlands, and (3) provided compensation for any remaining unavoidable impacts. According to the EPA, wetlands subject to CWA Section 404 are defined as "areas that are inundated or saturated by surface water or groundwater at a frequency and duration sufficient to support, and that under normal circumstances do support, a prevalence of 
vegetation typically adapted for life in saturated soil conditions. Wetlands generally include swamps, marshes, bogs, and similar areas” (EPA 2012a).

Proposed activities are regulated through a Section 404 permit review process. Two types of permits are possible: individual and general. Individual permits are required for projects that could have potentially significant impacts on the water body. General permits are issued for projects that would have only minimal adverse impacts on the water body. Individual permits are subject to more extensive review than are general permits. General permits allow certain activities to proceed with little delay. The U.S. Army Corps of Engineers (the Corps) and the EPA evaluate applications under a public interest review, and they also evaluate the environmental criteria set forth in the CWA Section 404(b)(1) Guidelines, and the Corps issues the permit.

\subsubsection{CWA Section 401}

According to the CWA, anyone who wishes to obtain a federal permit for any activity that may result in a discharge to navigable waters of the United States must first obtain a state Section 401 water quality certification to ensure that the project will comply with state water quality standards. The MPCA certifies activities requiring water quality certification under Section 401 of the CWA. For example, if a party proposes to discharge dredged or fill materials into navigable waters of the United States, including wetlands, it must obtain a Section 404 permit from the Corps (as described above) and a Section 401 water quality certification from the MPCA. The Section 404 Corps permit is the most common federal permit issued in Minnesota requiring a Section 401 determination from the MPCA.

According to the MPCA (2012b), Section 401 authority is used to review Section 404 Corps permit applications for projects that:

1. Are within areas that directly drain to impaired waters (or those that are close to being impaired), Outstanding Resource Value Waters (ORVWs), or trout waters;

2. Affect more than 3 acres of private project lands or 5 acres of wetlands within $0.5 \mathrm{mi}$ of listed impaired waters (smaller projects with special concerns may also be considered);

3. Have the potential to inundate or deepen by excavation more than 2 acres of wetland or are otherwise not regulated by the Wetlands Conservation Act (WCA) (see Section 2.2.1.1); or

4. Result in typically large wetland fills or drainage (e.g., projects like mining activities, multipurpose roads with new bed alignments, new judicial ditching that has the potential to affect downstream waters, flood impoundment or diversion projects, large development and other projects that may have adverse impacts on the watershed). 
During the review process, the MPCA ensures the project will be in compliance with state water quality standards. The MPCA also evaluates whether there are any reasonable alternatives to impacting the wetland, how to minimize the project's impact on the wetland, and how to implement adequate compensatory mitigation to protect the designated uses of the wetland and the water quality standards of the affected watershed. If the MPCA grants a 401 water quality certification, the Corps will complete the public interest review before granting or denying the Section 404 permit. Any conditions required to meet water quality standards included in the Section 401 water quality certification become conditions of the Section 404 permit. If the MPCA denies the Section 401 water quality certification, the Corps must then deny the Section 404 permit.

\subsubsection{CWA Section 402 and Municipal Separate Storm Sewer Systems (MS4s)}

In 1987, the CWA was amended to require implementation of a two-phase comprehensive national program to address stormwater runoff. Phase I of the EPA's stormwater program was promulgated in 1990 under the CWA. Phase I relies on NPDES permit coverage to address stormwater runoff from (1) "medium" and "large” MS4s generally serving populations of 100,000 or more (such as Minneapolis and Saint Paul), (2) construction activity disturbing 5 or more acres of land, or (3) 10 categories of industrial activity. Phase II, issued in 1999, requires regulated small MS4s (e.g., those serving a population of less than 100,000) in urbanized areas (UAs), as well as small MS4s outside the UAs that are designated by the permitting authority, to obtain NPDES permit coverage for their stormwater discharges. Phase II also covers stormwater discharges from construction sites that disturb 1 to 5 acres. The Phase II rule automatically covers MS4s located in UAs, which are defined by the U.S. Census Bureau in EPA (2012b) as:

“... a densely settled core of census tracts and/or census blocks that have population of at least 50,000, along with adjacent territory containing non-residential urban land uses as well as territory with low population density included to link outlying densely settled territory with the densely settled core.”

The U.S. Census Bureau calculates the geographic boundaries of the most heavily developed and dense urban areas. Any and all operators of small MS4s located within the boundaries of the UA are covered under the Phase II rule. The EPA delegated regulation of the CWA to the MPCA. Under Chapters 7090 and 7001 of the Minnesota Rules, the MPCA has the authority to issue permits and regulate MS4 facilities. Chapter 7090 address the requirements of both the Phase I (NPDES) and Phase II (small MS4) federal regulations. Generally, Phase I MS4s are covered by individual permits and Phase II MS4s are covered by a general permit. Through the issuance of MS4 general permits, the MPCA is able to restore and maintain the integrity of Minnesota's waters. Managing urban stormwater runoff is an important part of the MPCA's plan to maintain water quality. Under the MS4 stormwater program, permitees are required to (1) develop a Stormwater Pollution Prevention Plan (SWPPP), (2) implement the SWPPP using stormwater best management practices (BMPs), (3) develop measurable goals for the program, and (4) evaluate the effectiveness of the program. 


\subsubsection{Safe Drinking Water Act (SDWA)}

The SDWA (42 U.S.C. §300f et seq.) was passed in 1974 with the purpose of protecting the quality of drinking water in the United States. The law was amended in 1986 and 1996. It requires many actions to protect drinking water and its sources: rivers, lakes, reservoirs, springs, and groundwater wells. The SDWA grants the EPA the authority to establish minimum standards to protect tap water and requires all owners or operators of public water systems to comply with these primary (health-related) standards. The standards protect drinking water from both naturally occurring and manmade contaminants. Each standard also includes requirements for water systems to test for contaminants in the water to make sure standards are achieved. The Minnesota Department of Health oversees the implementation of the SDWA in Minnesota through the activities of its Drinking Water Protection Program.

\subsubsection{Energy Independence and Security Act (EISA)}

The EISA of 2007 (Public Law [P.L. 110-140]) establishes energy reduction goals and requirements. The stated purpose of the act is "to move the United States toward greater energy independence and security, to increase the production of clean renewable fuels, to protect consumers, to increase the efficiency of products, buildings, and vehicles, to promote research on and deploy greenhouse gas capture and storage options, and to improve the energy performance of the Federal Government, and for other purposes” (EISA 2007).

\subsubsection{EISA Section 438}

Under Section 438 of the EISA, Congress requires federal agencies to provide national leadership to reduce water quality problems from stormwater runoff and established EISA 438 strict stormwater runoff requirements for federal development and redevelopment projects. The purpose of EISA Section 438 is to replicate the predevelopment hydrology to protect and preserve the water resources both on site and downstream. Pursuant to Section 14 of Executive Order (E.O.) 13514 (which sets a policy that federal agencies "conserve and protect water resources through efficiency, reuse, and stormwater management” (E.O. 13514 2009), the EPA has issued guidance on implementing Section 438 of the EISA. Section 438 of the EISA reads as follows (EISA 2007):

“The sponsor of any development or redevelopment project involving a federal facility with a footprint that exceeds 5,000 square feet shall use site planning, design, construction, and maintenance strategies for the property to maintain or restore, to the maximum extent technically feasible, the predevelopment hydrology of the property with regard to the temperature, rate, volume, and duration of flow."

Section 438 requires federal agencies to develop and redevelop facilities with a footprint exceeding 5,000 $\mathrm{ft}^{2}$ in a manner that maintains or restores the predevelopment site hydrology to the maximum extent technically feasible. (The cantonment area of the AHATS facility is 
approximately 300 acres.) Agencies have two options to demonstrate that they are maintaining predevelopment hydrology (EPA 2009):

1. Manage on site the total volume of rainfall from the 95th percentile storm or

2. Manage on site the total volume of rainfall based on a site-specific hydrologic analysis.

Option 1 (retaining the 95th percentile rainfall event) is a performance-based, simplified approach that site designers can use to meet Section 438. Option 2 (site-based hydrologic analysis) allows the site designer to conduct a hydrologic analysis of the site based on sitespecific conditions (EPA 2009). When choosing Option 1, designers use a predetermined formula to estimate the amount of stormwater required to be managed on site. When choosing Option 2, predevelopment hydrology is "determined based on site-specific conditions and local meteorology by using continuous simulation modeling techniques, published data, studies, or other established tools" (EPA 2009). Federal agencies can comply with Section 438 by using a variety of stormwater management practices, as outlined in the EPA guidance document. These stormwater management practices are often referred to as "green infrastructure" or "low-impact development” practices (e.g., green roofs and rain gardens) and allow stormwater to be retained on site rather than flowing to municipal stormwater sewers. The result of complying with Section 438 of the EISA and implementing stormwater management practices should be to mimic the predevelopment hydrology of the site after (post) development. Although AHATS is a state organization, it has a federal mission and receives federal funding. AHATS therefore follows E.O. 13514 and Section 438 of the EISA.

\subsection{RAMSEY COUNTY REGULATIONS}

\subsubsection{Ramsey Conservation District (RCD)}

The RCD is a special-purpose local unit of government established to assist citizens of Ramsey County in their stewardship of land and water resources. The RCD assists public and private land owners in countywide programs for natural resource conservation.

\subsubsection{RCD and Enforcement of the Wetlands Conservation Act}

The Minnesota State Legislature passed the WCA in 1991. According to the Minnesota Board of Water and Soil Resources (BWSR, the Minnesota agency that administers the act), the WCA was enacted to maintain and protect Minnesota's wetlands and the benefits they provide. The WCA, in Chapter 8400 of the Minnesota Rules, requires anyone proposing to drain, fill, or excavate a wetland to first try to avoid disturbing it; second, try to minimize any impact on it; and third, replace any lost wetland acres, functions, or values. The Minnesota Department of Natural Resources (DNR) enforces the WCA, while the RCD implements the act locally, with funding from BWSR. As part of its WCA activities, RCD: 
- Provides a member to serve on a Technical Evaluation Panel when any project could impact a wetland,

- Assists the Minnesota DNR and local government units to enforce the WCA,

- Reports wetland statistics to the BWSR, and

- Attends training sessions and conferences to keep up to date on WCA policies and enforcement (RCD 2012).

According to the U.S. Fish and Wildlife Service (USFWS 2012), Marsden Marsh is classified as a Freshwater Emergent Wetland, which is defined as a herbaceous marsh, fen, swale or wet meadow. Certain wetland activities are exempt from the act, allowing projects with minimal impact or projects located on land where certain pre-established land uses are present to proceed without regulation.

\subsection{RICE CREEK WATERSHED DISTRICT (RCWD) REGULATIONS}

A Watershed District is a local unit of government authorized under Minnesota Statute 103D, whose goal is to conserve natural resources through land use planning, flood control, and other conservation projects. A Watershed District's political boundaries roughly follow the boundary of the natural watershed it is managing rather than typical political boundaries. The RCWD is located primarily in Anoka, Ramsey, and Washington Counties, with a small portion being in Hennepin County. The legal boundary of the RCWD encompasses approximately $186 \mathrm{mi}^{2}$ of urban and rural land, with portions in 28 cities and townships, along the Rice Creek Watershed. The RCWD has legal jurisdiction over all the wetlands within its boundaries.

\subsubsection{RCWD General Rules}

RCWD General Rules were adopted on February 13, 2008, and they apply to the entire Watershed District. They were adopted to protect the public's health and welfare as well as the natural resources of the RCWD and are enforceable under Minnesota Statute. Rule C of the General Rules pertains to SWMPs for managing stormwater and snowmelt runoff on a local, regional, or subwatershed basis and for promoting natural infiltration of runoff throughout the RCWD (RCWD 2008).

\subsubsection{RCWD Watershed Management Plan (WMP)}

The RCWD WMP provides the guidance and implementation for the RCWD to manage the water and natural resources of the District into the foreseeable future, extending through 2020 (RCWD 2012b). It serves as the WMP required under Minnesota Statutes 103B and 103D 
and Minnesota Rule 8410. The WMP divides the RCWD into five planning areas based on hydrologic boundaries, and it outlines resources, actions, and efforts for all the water resources and issues in the RCWD. The WMP identifies problems and opportunities within the District and presents watershed goals, with policies and actions to support these goals. An important feature of the WMP is also that it lays out an implementation plan for projects and programs that the RCWD will need to carry out to accomplish its goals. The WMP acknowledges that stormwater management policies and projects are an integral part of its planning efforts. To facilitate actions to improve stormwater management in existing urban-density areas, RCWD administers a costshare program to provide financial assistance to local land use and public works authorities for retrofit projects for water quality improvements (RCWD 2012c). Section 2.5 describes the BMPs that may be eligible for RCWD's cost-share program.

\subsubsection{RCWD Permitting for Development}

Filling, draining, or excavating the wetlands within RCWD requires a permit and generally requires mitigation wetlands twice the size of impacted wetlands, depending on location factors (Tomczik 2013). In addition, these activities require the applicant to provide appropriate justification for impacting the wetland.

Permits are required for several development scenarios, including industrial, commercial, institutional, or multi-unit residential development or redevelopment on a parcel equal to or larger than 1 acre in size (RCWD 2012a). Permit applications are submitted to the RCWD, and the RCWD reviews the information and grants approval when appropriate.

\subsection{CITY OF ARDEN HILLS REQUIREMENTS}

\subsubsection{City of Arden Hills MS4 Permit and SWPPP}

The AHATS facility is located in the City of Arden Hills and thus subject to the requirements outlined in the city's MS4 Permit MN R 040000 (Arden Hills 2006). As part of the NPDES Phase II permit, the City of Arden Hills is required to develop a SWPPP to reduce the discharge of pollutants from the storm sewer system to the maximum extent practicable. The SWPPP (Arden Hills 2006) must cover the following six minimum control measures:

- Public education and outreach,

- Public participation/involvement,

- Illicit discharge detection and elimination,

- Construction site stormwater runoff control,

- Post-construction stormwater management, and 
- Pollution prevention/good housekeeping for municipal operations.

The SWPPP must identify BMPs and measurable goals associated with each minimum control measure. The BMPs to meet the minimum control measures set forth in the Arden Hills SWPPP (Arden Hills 2006) are summarized in Table 2. The theme areas in this table, along with the individual BMPs, provide a comprehensive set of measures to address not only the operational aspects of protecting stormwater, but also the public communication and education aspects.

The Arden Hills MS4 permit also describes BMPs that the City will employ to review discharges into impaired waters and to review any potential for stormwater to contaminate the groundwater supply.

\subsection{CONSTRUCTION STORMWATER PERMIT}

MPCA administers the construction stormwater permit program for the State. The application for such a permit requires a description of the construction activity, a site map showing details relevant to stormwater planning, identification of trained personnel to oversee BMP implementation, and descriptions of specific erosion prevention and sediment control BMPs, including treatment systems (MPCA 2009). The proximity of AHATS to Rice Creek, which is impaired, may trigger additional BMPs if a project site is within one mile of Rice Creek and is discharging runoff to it. This includes permanent stormwater management features to handle one inch of runoff from new impervious surfaces. 


\title{
TABLE 2 Summary of SWPPP BMPs Used To Meet the Minimum Control Measures of the Arden Hills SWPPP
}

\author{
Minimum Control Measures
}

\begin{tabular}{|c|c|c|c|c|c|c|}
\hline & $\begin{array}{c}\text { Public Education } \\
\text { and Outreach }\end{array}$ & $\begin{array}{c}\text { Public Participation and } \\
\text { Involvement }\end{array}$ & $\begin{array}{c}\text { Illicit Discharge, } \\
\text { Detection, and } \\
\text { Elimination }\end{array}$ & $\begin{array}{c}\text { Construction Site } \\
\text { Stormwater Runoff } \\
\text { Control } \\
\end{array}$ & $\begin{array}{l}\text { Post-Construction } \\
\text { Stormwater Management }\end{array}$ & $\begin{array}{l}\text { Pollution Prevention for } \\
\text { Municipal Operations }\end{array}$ \\
\hline 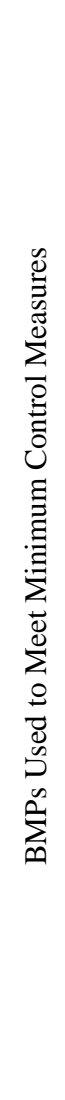 & $\begin{array}{l}\text { - Distribute educational } \\
\text { materials } \\
\text { - Implement an } \\
\text { Education Program } \\
\text { - Education Programs: } \\
\text { Public Education and } \\
\text { Outreach; Public } \\
\text { Participation; Illicit } \\
\text { Discharge Detection } \\
\text { and Elimination; } \\
\text { Construction Site } \\
\text { Runoff Control; Post- } \\
\text { Construction } \\
\text { Stormwater } \\
\text { Management; and } \\
\text { Pollution Prevention } \\
\text { for Municipal } \\
\text { Operations } \\
\text { - Coordinate Education } \\
\text { Program } \\
\text { - Conduct annual public } \\
\text { meeting }\end{array}$ & $\begin{array}{l}\text { - Comply with Public } \\
\text { Notice requirements } \\
\text { - Solicit public input } \\
\text { and opinions on the } \\
\text { adequacy of the SWPP } \\
\text { - Consider public input }\end{array}$ & $\begin{array}{l}\text { - Storm sewer system } \\
\text { map } \\
\text { - Regulatory Control } \\
\text { Program } \\
\text { - Illicit Discharge } \\
\text { Detection and } \\
\text { Elimination Plan } \\
\text { - Public and Employee } \\
\text { Illicit Discharge } \\
\text { Information Program } \\
\text { - Identify } \\
\text { non-stormwater } \\
\text { discharges and flows }\end{array}$ & $\begin{array}{l}\text { - Establish ordinance or } \\
\text { other regulatory } \\
\text { mechanism } \\
\text { - At construction site, } \\
\text { implement erosion and } \\
\text { sediment control } \\
\text { BMPs } \\
\text { - Establish waste } \\
\text { controls for } \\
\text { construction site } \\
\text { operators } \\
\text { - Implement procedure } \\
\text { for Site Plan review } \\
\text { - Establish procedures } \\
\text { for the receipt and } \\
\text { consideration of } \\
\text { reports of stormwater } \\
\text { noncompliance } \\
\text { - Establish procedures } \\
\text { for site inspections and } \\
\text { enforcement }\end{array}$ & $\begin{array}{l}\text { - Develop and } \\
\text { implement structural } \\
\text { and/or nonstructural } \\
\text { BMPs } \\
\text { - Establish regulatory } \\
\text { mechanism to address } \\
\text { post- construction } \\
\text { runoff } \\
\text { - Conduct long-term } \\
\text { operation and } \\
\text { maintenance of BMPs }\end{array}$ & $\begin{array}{l}\text { - Oversee municipal } \\
\text { Operations and } \\
\text { Maintenance Program } \\
\text { - Conduct street } \\
\text { sweeping } \\
\text { - Conduct annual } \\
\text { inspection of pollution } \\
\text { control devices } \\
\text { - Inspect 20\% of the } \\
\text { MS4 outfalls, sediment } \\
\text { basins, and ponds each } \\
\text { year on a rotating basis } \\
\text { - Conduct annual } \\
\text { inspection of all } \\
\text { exposed stockpiles and } \\
\text { storage and material } \\
\text { handling areas. } \\
\text { - Conduct inspection } \\
\text { follow-up } \\
\text { - Fill out reports on and } \\
\text { retain records of all } \\
\text { inspections and } \\
\text { responses to } \\
\text { inspections } \\
\text { - Evaluate the frequency } \\
\text { of inspections }\end{array}$ \\
\hline
\end{tabular}

Source: Arden Hills (2006) 


\section{BEST MANAGEMENT PRACTICES}

BMPs for controlling stormwater should be employed throughout a facility's property to help meet regulatory requirements for flow rate and water quality and quantity of stormwater runoff. BMPs are defined in the City of Arden Hills’ Erosion and Sediment Control Ordinance as:

“...schedules of activities, prohibitions of practices, general good housekeeping practices, pollution prevention and educational practices, maintenance procedures, and other management practices to prevent or reduce the discharge of pollutants directly or indirectly to stormwater, receiving waters, or stormwater conveyance systems. BMPs also include treatment practices, operating procedures, and practices to control site runoff, spillage or leaks, sludge or water disposal, or drainage from raw materials storage” (Arden Hills 2011).

BMPs may be structural or nonstructural. Nonstructural BMPs are practices focusing on preserving open space, minimizing disturbed areas, protecting natural systems, and incorporating existing landscape features such as wetlands and stream corridors to manage stormwater at its source (Arden Hills 2011). Conversely, structural BMPs are physical devises that reduce runoff velocities or allow stormwater to be trapped and/or filtered. Stormwater management outcomes may be achieved by employing any nonstructural or structural BMP, or, more commonly, a combination of many BMPs into a system to treat and store stormwater.

\subsection{NONSTRUCTURAL BMPS}

Nonstructural BMPs may be employed during the planning stages of development; their intent is to minimize any adverse impacts of development. The practices are intended to prevent pollution and minimize increases in the volume of stormwater, and they are considered before construction activity begins. Nonstructural BMPs may be employed to achieve the following (MPCA 2012c):

- Prevent pollution,

- Improve site design,

- Minimize the volume of stormwater runoff, and

- Control sediment from construction activities.

\subsubsection{Pollution Prevention Practices}

Stormwater may be harmful to natural waterways because it serves as a conveyance for pollutants found on roadways, construction sites, or rooftops. Pollutants (e.g., sediment, oil, pesticides, herbicides, salt, animal waste, heavy metals) are washed away from these surfaces and carried into sewers or waterways. Certain practices can minimize the availability of such substances on these surfaces. They include practices like the following (MPCA 2012c): 
- Housekeeping, including landscaping, street sweeping, pavement maintenance, catch basin maintenance, yard waste reduction, and litter control;

- Atmospheric controls, including those addressing wind erosion and dust, as well as regulatory emission regulations;

- Chemical control of hazardous waste and salt, fertilizer/pesticides, and spills (including prevention);

- Animal waste management;

- Stream-bank stabilization; and

- Public works activities, including those addressing chemical and sanitary wastes and sewer maintenance.

\subsubsection{Improved Site Design}

Many practices can be employed to improve stormwater control through the design development. These practices are based on the fact that natural areas are better than impervious surfaces at allowing water to slowly seep into the ground. Impervious surfaces (i.e., those that water is unable to permeate) also collect dust and toxins. The practices include these (MPCA 2012c):

- Preserving natural areas through

- Natural area conservation,

- Site reforestation,

- Stream and shoreline buffers, and

- Open space design;

- Disconnecting and distributing runoff through

- Soil compost amendments,

- Disconnection of surface impervious cover,

- Rooftop disconnection,

- Grass channels,

- Stormwater landscaping; and

- Reducing impervious cover in site design through

- Narrower streets,

- Slimmer sidewalks,

- Smaller cul-de-sacs,

- Shorter driveways, and

- Smaller parking lots. 


\subsubsection{Runoff Volume Minimization}

Many of the above site design practices may also reduce the volume of stormwater runoff going into storm sewers and natural waterways. Typical runoff volume reduction measures are techniques for holding stormwater during a storm event and releasing it at a reduced rate and/or at a later time when the receiving sewers or naturals waterways are not as stressed. These measures may include the following (MPCA 2012c):

- Green roofs/rooftop gardens,

- Pervious pavement/lattice blocks, and

- Rainwater harvesting (barrels/cisterns, evaporative and irrigation systems).

\subsubsection{Construction Sediment Control}

During the construction of new facilities, stormwater can carry sediments, construction debris, and harmful chemicals into storm sewers and waterways. Stormwater management techniques can reduce the adverse impact of stormwater runoff by using practices that include these (MPCA 2012c):

- Vegetated buffers,

- Silt fence,

- Access/egress and drainage inlet protection,

- Soil and slope stabilization, and

- Exposed soil covers and reinforcement.

\subsection{STRUCTURAL BMPS}

As mentioned previously, structural BMPs involve the use of physical devices to collect, store, and filter stormwater. These techniques may be employed before, during, and after development activities to reduce the adverse impacts of stormwater runoff. Structural BMP devices may be specific to the development project by determining the storage volume, filtration capacity, and other physical configurations that will produce the best outcome. These BMPs may be combined with other structural or nonstructural BMPs as well. Structural BMPs may include these (MPCA 2012c):

- Bioretention,

- Filtration,

- Infiltration, and

- Stormwater ponds.

\subsubsection{Bioretention}

This BMP group includes vegetated systems that provide a combination of filtration and infiltration into a biological system consisting of plants and soil. These systems can be designed 
to hold various quantities of stormwater by selecting soils and plants with certain water retention properties. These BMPs include the following (MPCA 2012c):

- Rain gardens,

- Depressed parking lot/traffic islands,

- Road medians, and

- Tree pits/stormwater planters.

\subsubsection{Filtration}

These BMP devices are employed to remove sediment and toxins from stormwater. They may be used to treat stormwater before it is stored. They include these (MPCA 2012c):

- Media (sand) filters (surface, underground, perimeter),

- Surface (vegetative) flow (grass channels, dry or wet swales, filter strips), and

- Combination media/vegetative filters.

\subsubsection{Infiltration}

Infiltration systems allow stormwater on the surface to enter the soil, routing it away from sewers and natural water systems. However, the rate of infiltration may decrease as the soil becomes saturated, so these BMPs may be combined with other storage BMPs. Infiltration devices including the following (MPCA 2012c):

- Trenches,

- Basins,

- Dry wells, and

- Underground systems.

\subsubsection{Stormwater Ponds}

Stormwater ponds are large depressions where stormwater may be stored after a rain event. The surrounding area may be designed with contours so that stormwater runoff flows downward into the pond, guided only by the force of gravity. Design components may include some pretreatment, various storage volumes, and the physical configuration. Functions include water quality (including thermal impact) and flow control (rate and volume). The design for flow control, along with basin permeability and depth to groundwater, determine whether the depressions are typically wet or dry. A wet detention pond includes a permanent pool with additional storage capacity, while a dry pond has no permanent pool. A dry pond provides rate control but allows sediment resuspension (MPCA 2012c). 


\subsubsection{Constructed Wetlands}

Constructed wetlands are similar to stormwater ponds but include additional biological factors at or near the basin that may be designed into the system to satisfy additional treatment and storage needs. They may function solely as water quality and flow control, but may also include ecological factors. Components include pre-treatment, various storage volumes (detention needed), biologic character (MPCA 2012c).

\subsection{EPA TECHNICAL GUIDANCE ON IMPLEMENTING EISA SECTION 438}

As described in Section 2.1.3.1, federal agencies that want to demonstrate that they are maintaining predevelopment hydrology have two options:

1. They can manage on site the total volume of rainfall from the 95th percentile storm or

2. They can manage on site the total volume of rainfall based on a site-specific hydrologic analysis.

Federal agencies can comply with Section 438 by using a variety of stormwater BMPs, many of which are described in the EPA's Technical Guidance on Implementing the Stormwater Runoff Requirements for Federal Projects under Section 438 of the Energy Independence and Security Act (EPA 2009). EPA (2009) recommends "that the federal facility use all known, available and reasonable methods of stormwater retention and/or use to the maximum extent technically feasible (METF).” Regardless of whether the facility designers choose to manage on site the total volume of rainfall from the 95th percentile storm or the total volume based on a site-specific hydrologic analysis, "this objective should be accomplished by the use of practices that infiltrate, evapotranspire and/or harvest and use rainwater” (EPA 2009).

EPA (2009) suggests the following list of measures be used to infiltrate, evapotranspire, and/or harvest stormwater:

- Trenches;

- Basins;

- $\quad$ Rain gardens, bioretention, and infiltration planters;

- $\quad$ Porous pavements;

- Vegetated swales and bioswales;

- Green roofs; 
- $\quad$ Trees and tree boxes;

- Pocket wetlands;

- Reforestation/revegetation using native plants;

- Protection and enhancement of riparian buffers and floodplains; and

- Rainwater harvesting for various uses (e.g., irrigation; heating, ventilation, and air-conditioning [HVAC] make-up; nonpotable indoor uses).

These measures may be structural or nonstructural BMPs. For example, pocket wetlands, revegetation using native plants, and protection of riparian buffers are nonstructural BMPs, whereas rain gardens, trenches, and tree boxes are structural BMPs. By employing a collection of these BMPs, facility designers can comply with Section 438 of the EISA and mimic the predevelopment hydrology of the site.

\subsection{STATE OF MINNESOTA CONSTRUCTION GUIDELINES}

Construction activities at AHATS will follow the State of Minnesota Sustainable Building Guidelines (University of Minnesota 2009), which is part of the Buildings, Benchmarks and Beyond (B3) Project. The goal of B3 is to promote sustainable design as a means of reducing energy expenditures; enhancing the health, well-being, and productivity of the building occupants; and improving the quality of the natural environment. To meet these goals, the B3 guidelines include stormwater management performance criteria. The intent of the stormwater management guidelines is to

“... Minimize negative impacts on the natural site hydrologic cycle as much as possible by treating stormwater close to where it falls, reducing downstream impacts thereby improving the overall water quality and clarity, and recharging groundwater through infiltration as local soils and subsurface conditions allow and re-using stormwater wherever possible” (University of Minnesota 2009).

Building designers should implement a stormwater management plan that reduces impervious cover, promotes infiltration, and captures and treats the stormwater runoff both during and after construction. These stormwater guidelines will contribute to a higherperforming building with lower life-cycle costs.

\subsection{METROPOLITAN COUNCIL STORMWATER GUIDANCE}

\subsubsection{Metropolitan Area Master Water Supply Plan}

The Metropolitan Council (the Council) is the regional planning agency that serves the Twin Cities seven-county metropolitan area, within which the AHATS facility is located. The 
Council develops policy plans for regional water systems. The Council has two major water planning documents that dictate its policies regarding stormwater management. The Metropolitan Area Master Water Supply Plan (Metropolitan Council 2010a) was issued in response to Minnesota Statute 473.1565, which requires the Metropolitan Council to carry out activities addressing the water supply needs of the region. The goal of the plan is to guide sustainable water use in the Twin Cities metropolitan area and to integrate water supply planning into broader long-term planning for the region's development. The plan outlines seven principles to be carried out to guide regional water supply planning:

1. Water supply planning is an integral component of long-term regional and local comprehensive planning.

2. An understanding of the availability of and demand for the region's long-term water supply is needed for a specific community's or subregion's water sources to be identified.

3. All hydrologic system components, both those that are naturally occurring and those that are manmade, must be carefully evaluated when water infrastructure plans are being made.

4. The quality of the region's water is a critical component of water supply planning.

5. Interjurisdictional cooperation is a viable option for managing short-term water supply disruptions and for sustainably meeting long-term water supply needs.

6. Regional and local cost-effectiveness and equity are considered when water supply options are being identified.

7. Wise use of water supplies is critical to ensuring adequate supplies for future generations (Metropolitan Council 2010a).

Although, to some degree, stormwater management is relevant to all these principals, it most directly helps to carry out Principle 4 . The core of the plan is the water availability analysis, the community profiles that ensue from it, and the datasets that underlie it (Metropolitan Council 2010a). This information-gathering exercise will guide future water supply planning.

\subsubsection{Water Resources Management Policy Plan}

The Council has also developed policy on water resources management that may be applicable to development activities at the AHATS facility. State law (Minnesota Statutes, Section 473.145) directs the Council to prepare a comprehensive development guide for the metropolitan area for water systems. The Council's policy is outlined in Water Resources Management Policy Plan (the Policy Plan) (Metropolitan Council 2010b). The Policy Plan 
contains guidelines for developing and maintaining service systems that support development and for which the Council has some statutory responsibility (including wastewater service, surface water management, and regional water supply) and for incorporating these systems in overall regional development. The Council will also use the Policy Plan to review the waterrelated components of local comprehensive plans, including the surface water management, water supply, and wastewater components.

In order to manage surface water effectively, the Council encourages and supports the use of the most effective non-point-source pollution reduction technologies. These include lowimpact development practices and BMPs aimed at protecting water quality and maintaining stormwater runoff rates and volumes at or below predevelopment conditions (Metropolitan Council 2010b). The Council will review stormwater management plans to ensure that the local units of government are fulfilling their non-point-source reduction requirements and therefore not affecting the metropolitan disposal system. Policies to protect water supply also include reviewing stormwater management plans and working with partners in the region. To manage wastewater, it will be the Council's policy to establish inflow and infiltration goals for all communities that discharge wastewater to the Metropolitan Disposal System based on the designed peak-hour capacity of the interceptor(s) serving the community (Metropolitan Council 2010b). According to the Policy Plan, rainfall events put a lot of stress on the wastewater system's infrastructure. The Council will make the stormwater data that it collects from meters and points of inflow available to its partners. These water management policies allow the Council to work with partners to manage stormwater and to plan for development that will protect water supplies.

\subsubsection{BMPs of Urban Small Sites}

The Metropolitan Council partnered with Barr Engineering Company to publish Urban Small Sites Best Management Practice Manual (the Manual) (Barr Engineering and Metropolitan Council 2001). The Manual supports principles for accommodating growth while preserving the environment. It includes detailed information on $40 \mathrm{BMPs}$ aimed at managing stormwater pollution for small (less than 5 acres) urban sites in a cold-climate setting, such as the one in which the AHATS facility is located. The Manual serves as a tool to help Twin Cities area municipalities (e.g., Arden Hills) and watershed management organizations (e.g., RCWD) guide site development to protect water quality by effectively managing stormwater. The Manual guides decision makers in choosing the BMPs most suitable for a specific site. The Manual also describes in detail 40 structural and nonstructural BMPs and how best to implement them. The BMPs accomplish the two broader goals of pollution prevention and stormwater treatment. The pollution prevention BMPs include the following methods to prevent the release of non-pointsource pollution:

- Impervious surface reductions (reducing the amount of hard, impenetrable surfaces);

- Housekeeping techniques (basic cleanup and management practices); 
- Construction practices (ways to reduce opportunities for sediment to be released in stormwater);

- Soil erosion control (techniques to prevent exposed soils from eroding); and

- $\quad$ Sediment control (methods to catch sediment already suspended in stormwater) (Barr Engineering and Metropolitan Council 2001).

The Manual also includes stormwater treatment BMPs, which are grouped into six categories:

1. Infiltration systems (encourage stormwater to soak into the ground while filtering);

2. Filtration systems (capture heavy metals, grease and oil, and nutrients and sediment);

3. Constructed wetlands (filter stormwater and reduce runoff rate while providing wildlife habitat);

4. Retention systems (designed primarily to retain pollutants);

5. Detention systems (designed primarily to reduce runoff rate); and

6. Alternative outlet designs (primarily designed to regulate stormwater flow) (Barr Engineering and Metropolitan Council 2001).

These descriptions may serve as a resource for site design planners to employ during development to ensure that natural water systems will be protected from the adverse effects of stormwater runoff.

\subsection{RICE CREEK WATERSHED DISTRICT (RCWD) STORMWATER BMPS}

To protect and manage the water resources in the Rice Creek Watershed, the RCWD issues guidance and shares information and instructions regarding stormwater BMPs. The RCWD notes that "innovative BMPs constructed may be eligible for cost-share funding through one of the Rice Creek Watershed District's Grant Programs” (RCWD 2012c) such as the CostShare for Urban Stormwater Remediation Program, as outlined in Appendix C of RCWD's WMP (RCWD 2012c). RWCD provides guidance on implementing BMPs by providing considerations, specifications, sample plans, tools, and vendor lists for each of the following BMPs:

- Rain gardens,

- Infiltration trenches,

- Vegetated swales,

- Riparian restoration, 
- Pervious pavement,

- Green roofs, and

- Other BMPs (RCWD 2012c).

The guidance here helps those in the RCWD get started in managing stormwater by implementing these BMPs. By employing these BMPs, those in the RCWD can address three primary water quality concerns: its rate, volume, and quality. 


\section{WATERSHED MODELING}

\subsection{PURPOSE}

The success of stormwater management depends on an accurate analysis of the volume, rate, and quality of runoff moving through a watershed. The addition of buildings, parking lots, and other developed surfaces can have drastic impacts on stormwater flow. Replacing natural vegetation with impervious surfaces eliminates infiltration and generates faster-moving overland flows. The result can lead to on-site flooding when there is no proper assessment and there is no proper design. The areas receiving stormwater runoff from the newly constructed site would also see an increased water volume, which would likely affect the function of the existing drainage infrastructure. A comprehensive model allows for a better interpretation of runoff and accounts for many possible impacts from development. In this analysis, the entire AHATS property and upgradient areas were modeled to test various storm simulations to support a SWMP.

The majority of the approximately 1,500 acres of AHATS is open area and is used primarily for training exercises. In 2006, a cantonment area addition to the southernmost end of the property was proposed. The design calls for approximately 900,000 $\mathrm{ft}^{2}$ of facilities within the 300 acres of the new cantonment area (Jacobs 2009). Split into six phases, the project is currently in Phase 1, with the Arden Hills Readiness Center (AHRC) being completed, and the Field Maintenance Shop (FMS) building being under construction (Figure 3). The model examines:

- All likely paths of flow and coinciding basins within the AHATS property,

- Stormwater runoff and volume draining onto the property,

- Stormwater runoff and volume exiting the property,

- Stormwater runoff and volume exiting the cantonment area before construction, and

- Stormwater runoff and volume exiting the cantonment area and property upon the completion of the FMS site (following Minnesota Army National Guard [MNARNG] site plans dated May 10, 2010).

Two models were created to achieve this analysis. One was created for the AHATS property before Phase 1 construction, and the other was created for "current conditions." Current conditions is defined as the property with AHRC and FMS site construction, since it is designed upon completion of the FMS site. 


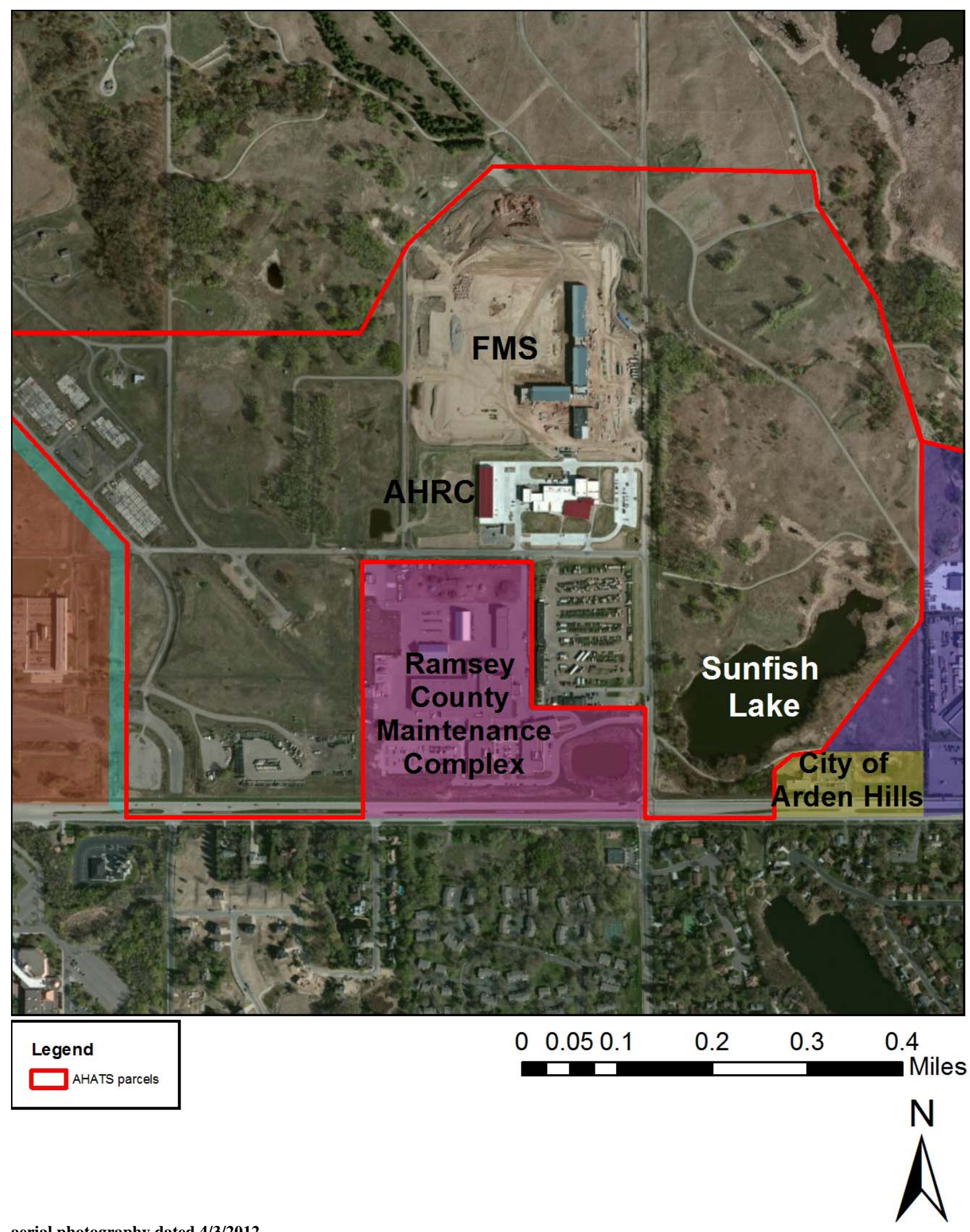

aerial photography dated $4 / 3 / 2012$

FIGURE 3 Cantonment Area's AHRC and FMS and Surroundings 


\subsection{APPROACH FOR SIMULATING THE STORMWATER RUNOFF}

\subsubsection{Model Selection}

Hydrologic models are tools that aim to replicate a physical landscape as closely as possible by using measured or estimated parameters. Different precipitation events can then be simulated to evaluate the response of surface flow. The slope of the terrain, area of pavement versus area of vegetation, and topsoil infiltration all affect how water will eventually reach the outlet of a watershed area. The Watershed Modeling System (WMS), a GIS-based framework for hydrologic models, was used to evaluate stormwater runoff from the AHATS property for its state of development upon completion of the FMS site. WMS allows the user to delineate watersheds based on an elevation data set, factor in geospatial landscaping and soil information, and apply an assortment of universally accepted hydrologic calculation methods. The program was selected for the AHATS study because of its GIS-like user interface and availability of a wide variety of hydrologic and hydraulic modeling systems. The development of WMS has been sponsored by the U.S. Department of Defense (DOD) and can therefore be obtained without cost for use in DOD studies.

\subsubsection{Watershed Delineation (before Phase 1 Construction)}

To account for flow at various places and to evaluate incoming and exiting water volumes, the AHATS property was divided into watersheds that are defined by expected flow paths from elevation data. Placing outlet points at key locations allows for the calculation of water volume through that point.

A digital elevation model (DEM) is a two-dimensional array of elevation points that replicate real-world, mapped terrain in a gridded data set. The DEM is an important aspect of modeling an area's watershed and is the foundation of the WMS model of AHATS that was developed. In 2001, a detailed light detection and ranging (LIDAR) survey was generated for Ramsey County. A 2-ft contour line data set (see Figure 4) of northwestern Ramsey County was extracted from the LIDAR. To account for the construction of the AHATS FMS site, the contour line set was merged with elevation contours derived from design drawings. The resulting elevation contours were then converted to a 1-m DEM in a format compatible with WMS. The DEM was large enough to cover not only the AHATS property but also the surrounding areas in order to address stormwater from off the site.

WMS has several tools to aid in the watershed delineation process. The package TOPAZ uses a DEM to create likely concentrated flow paths. Visualizing the gridded DEM as tiles, TOPAZ compares each tile's elevation to those of the surrounding tiles and assigns a flow direction on the basis of the neighboring tile with the lowest elevation. TOPAZ assigns an integer value to each tile corresponding to the cumulative number of tiles with flow directions leading to it. The highest-valued cells consequently have the most area of other cells "flowing" into them. The user then designates a threshold, which is the amount of area (which WMS geospatially relates to the number of contributing tiles) that will produce flow accumulation. The 
threshold was chosen to be $0.01 \mathrm{mi}^{2}$ for AHATS, which allows for detailed flow networks without overwhelming the area with unlikely tributary flows.

Although the evaluation of the topographic gradients to produce flow accumulation paths was initially based on the DEM, several manual adjustments needed to be made. TOPAZ attempts to patch incomplete DEMs by assigning the same elevation as that of surrounding cells to very-low-elevation cells. Consequently, TOPAZ will incorrectly adjust elevations of lakes, depression areas, and manmade obstacles (such as roads and parking lots). The manmade lake just west of North Hamline Avenue, an unnamed natural depression pond west of the cantonment area, and Sunfish Lake were defined manually from the TOPAZ output. These water bodies and their contributing regions are internally drained depressions with no outgoing flow and are consequently defined as separate subbasins (Figures 5 and 6).

After careful examination of the terrain, several locations were identified where the flow within the preliminary model traveled across roads instead of along roadside ditches. These alterations from the original TOPAZ accumulation paths were confirmed with aerial imagery and culvert locations, and flow accumulations and watershed boundaries were modified to better match likely stormwater paths (Figure 7). Specifically, revisions in the flow paths were made along the three larger roads outlining AHATS at the north side of the property along County Highway 3, along Lexington Avenue on the east, along Highway 96 on the south, and along a series of smaller roads along the southern border of the property. Smaller roads affecting the flood pathways were Lower Magazine Road, Upper Magazine Road, North Magazine Road, Hamline Avenue, and Callaghan Street/Ben Franklin Street. These roads and the locations of culverts can be seen in Figure 8. A modification in flow was also necessary to account for the Ramsey Maintenance Complex, which was not complete when the LIDAR map was created. The resulting watersheds appear in Figures 5 and 6 and are explained in greater detail in the model results section.

Outlet points are selected manually along flow paths to define subbasin outlet locations (Figures 5 and 6). From these flow accumulation paths and their respective outlet points, WMS assigns watershed boundaries. Outlets are placed at locations where the flow accumulation exits the property and at the three pond locations previously mentioned. An outlet is also placed along the southeast side of the property where a culvert under Lexington Avenue allows off-site water to enter the AHATS property. This creates a separate subbasin so that an evaluation of the amount of incoming water through the culvert can be made. A final outlet is placed to the east of the FMS site to create a subbasin that will allow calculations of the approximate amount of contributing runoff from the future cantonment area. Once all the outlets were correctly placed and the watersheds were created, the basins were manually adjusted to reflect the relocation of the streams along the roads mentioned previously. 


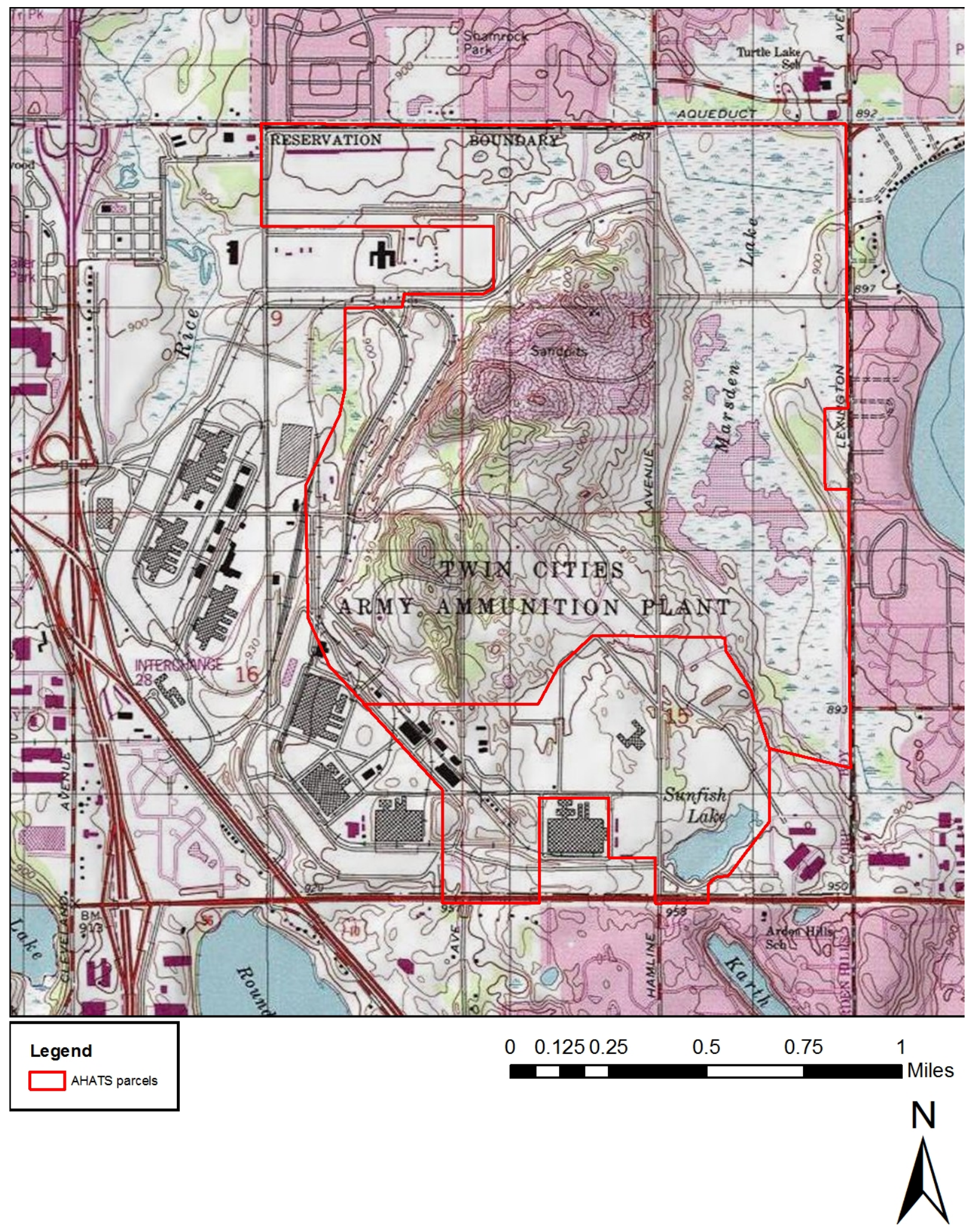

FIGURE 4 Topographic Contours of the AHATS Property 


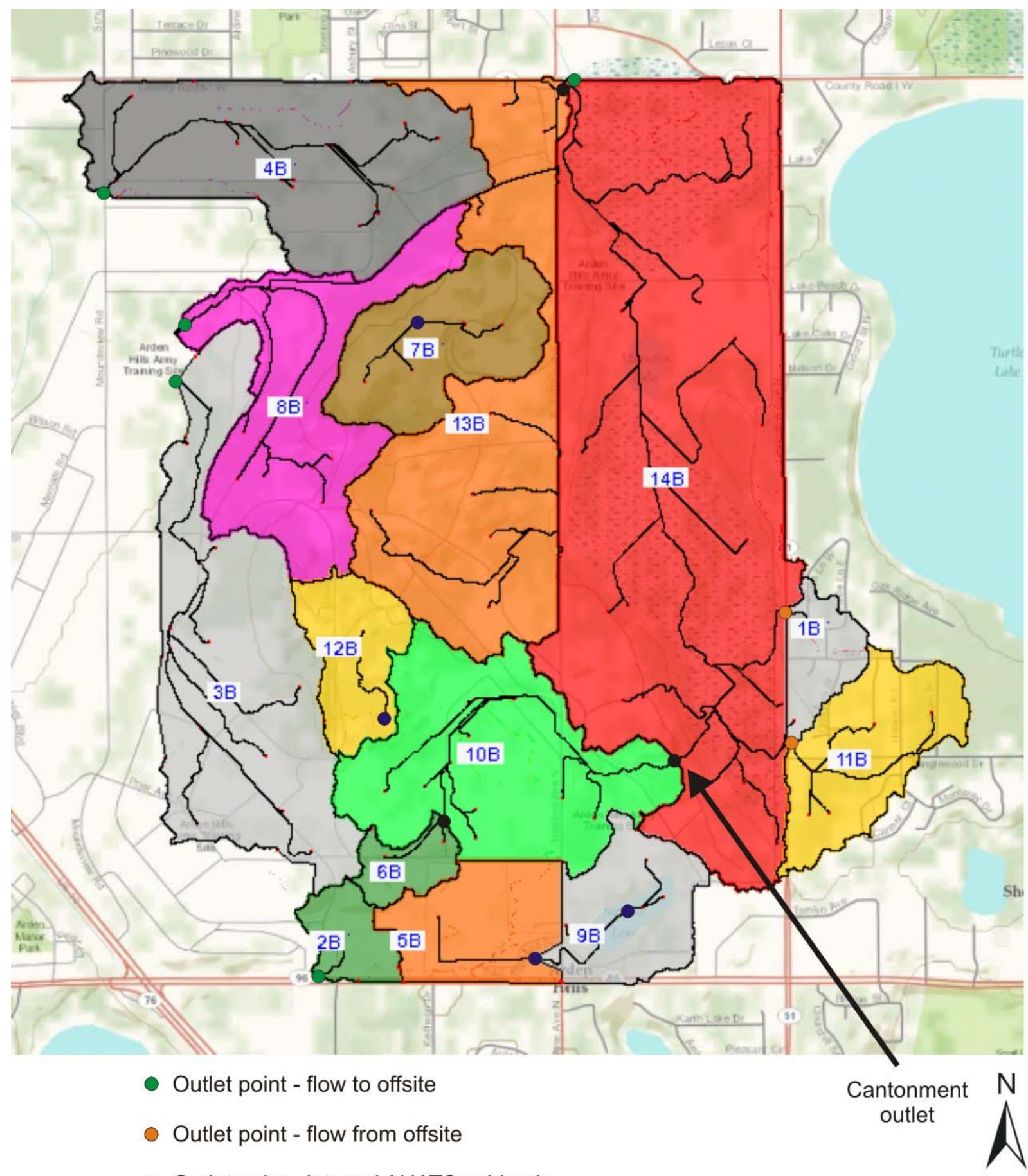

- Outlet point - internal AHATS subbasin

- Outlet point - flow to closed depression (pond or lake)

Black lines show drainageways or subbasin boundaries

FIGURE 5 Basins and Outlet Points in the Study Area Before Phase 1 Construction 


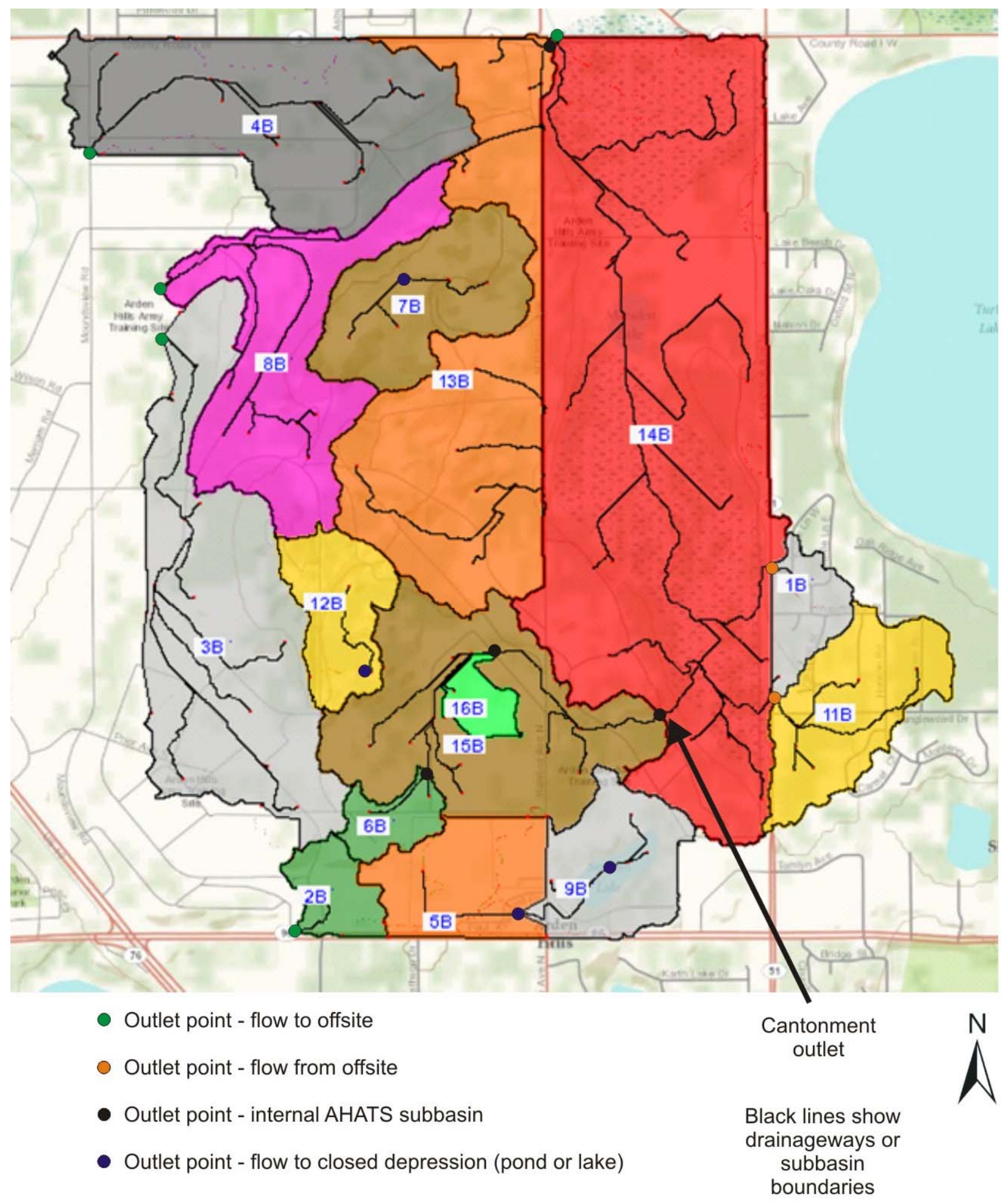

FIGURE 6 Basins and Outlet Points in the Study Area After Phase 1 Construction 


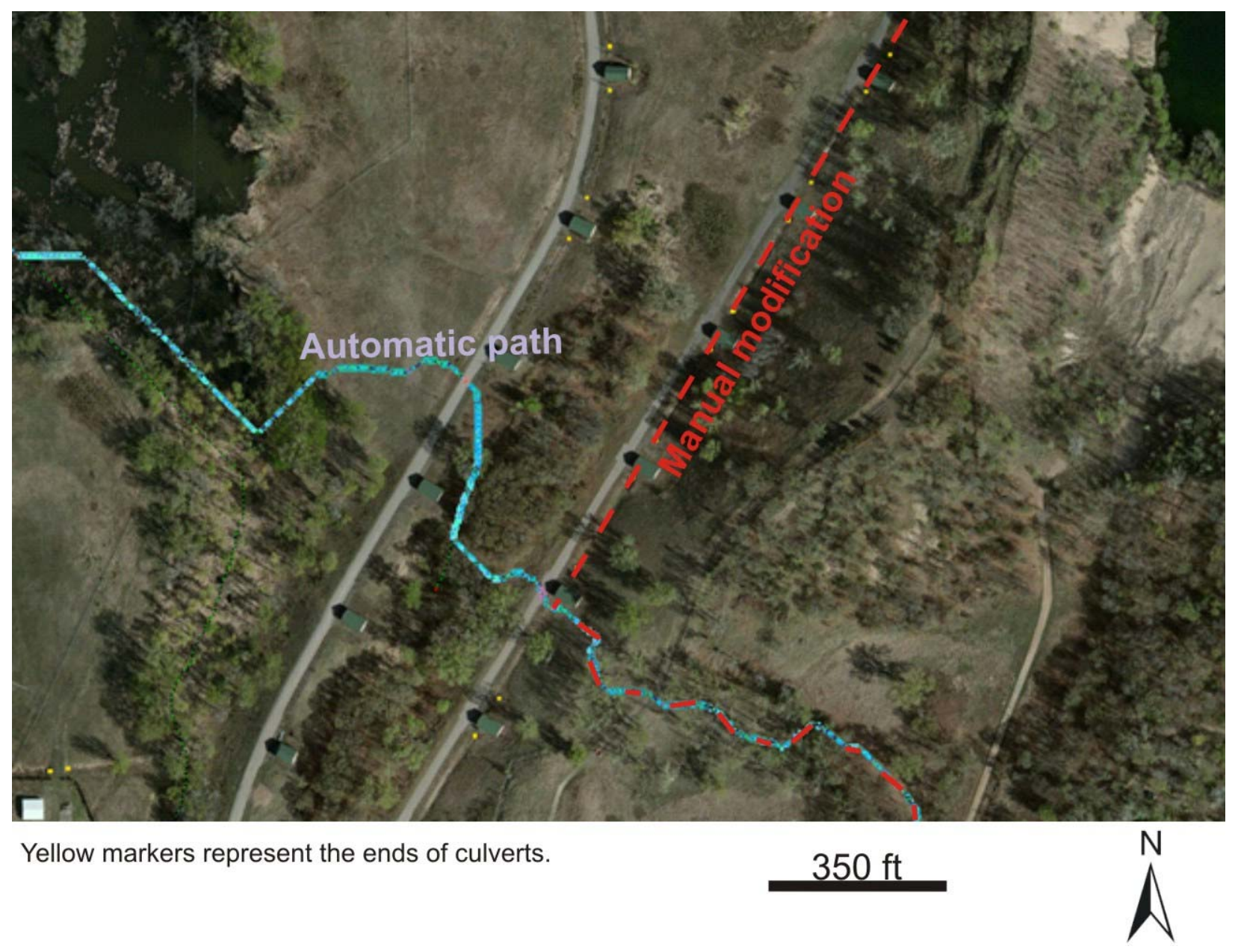

FIGURE 7 Example of a Flow Accumulation Path that Needed to be Manually Modified Because of Existing Stormwater Structures 


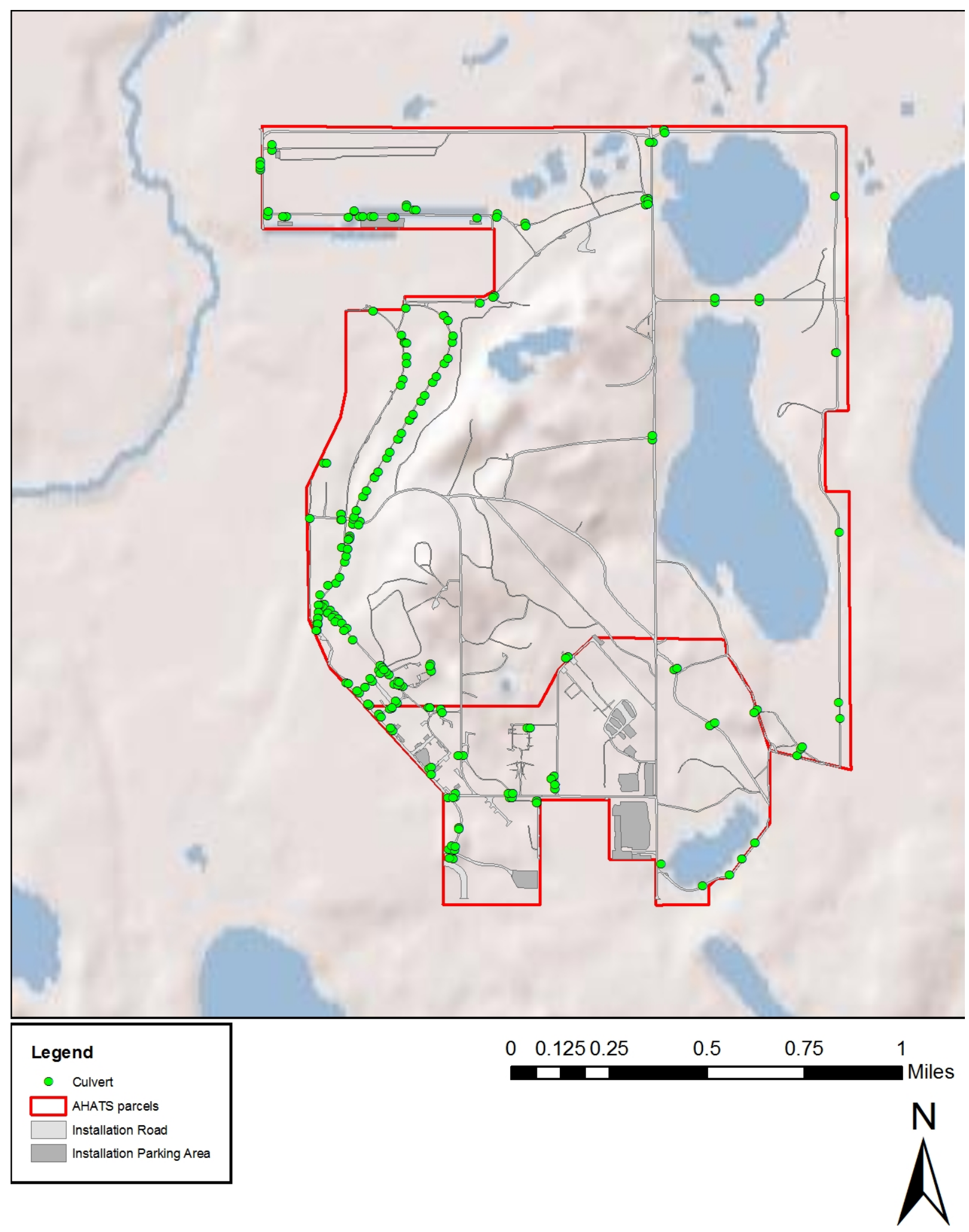

FIGURE 8 Road and Culvert Locations 


\subsection{APPROACH FOR ESTIMATING STORMWATER RUNOFF}

Once the watershed areas were created, the Natural Resources Conservation Service (NRCS, formerly Soil Conservation Service or SCS) procedure to assess stormwater runoff was used to prepare data on the approximated runoff potential from storm events (USDA 1986). The Technical Release 55 (TR-55) procedure is a widely used approach to calculate runoff volumes and peak discharge rates. This approach, sometimes called the SCS method, is applicable to small watersheds. In the method, an integer value between 1 and 99 called the curve number (CN) is assigned to each area of different hydrologic properties in a basin. The CN represents runoff conditions based on a combination of the soil characteristics and land cover. Based on the $\mathrm{CN}$, the TR-55 procedure converts mass rainfall to a maximum, or peak, runoff for each basin, which can be used to estimate flooding events and/or the capacity of stormwater structures.

\subsubsection{Curve Number}

The CN essentially defines the infiltration rate of the land area taking both soil and land use parameters into consideration. The soil information used for this procedure consisted of sitespecific data provided by the Minnesota Army National Guard for the AHATS property area and a countywide map from NRCS's Soil Survey Geographic Database (SSURGO). The SSURGO data were downloaded for off-site areas draining onto the AHATS property. The two data layers were joined to create a combined soil map (Figure 9). The specific soil types were assigned to one of the four hydrologic soil groups - A, B, C, or D - for the entire study. Table 3 is modified from TR-55 data (USDA 1986) and explains the characteristics of each soil group type. The land use information for the AHATS property was also site-specific and provided by the Minnesota Army National Guard. For off-site areas, land use data were derived from a geospatial layer from the National Land Cover Database (NLCD). The merged layer can be seen in Figure 10 .

For the AHATS watersheds, WMS was used to overlay both the soil and land use information and determine the areas where the overlapping layers make different combinations of soil and land use. Referencing Table 2-2a in the TR-55 manual (USDA 1986), each combination of hydrologic soil group and land usage was assigned a CN (Table 4). The individual zones of $\mathrm{CN}$ values and areas (A) were averaged by using the following equation for each basin to acquire a composite $\mathrm{CN}$ for each subbasin:

$$
\text { Weighted } C N=\frac{C N_{1} A_{1}+C N_{2} A_{2}+\cdots+C N_{n} A_{n}}{\sum A_{n}}
$$

This process of weighting the $\mathrm{CN}$ produces a much better representation of a basin than simply assigning one CN. The CN approximations are shown in Appendix A. 


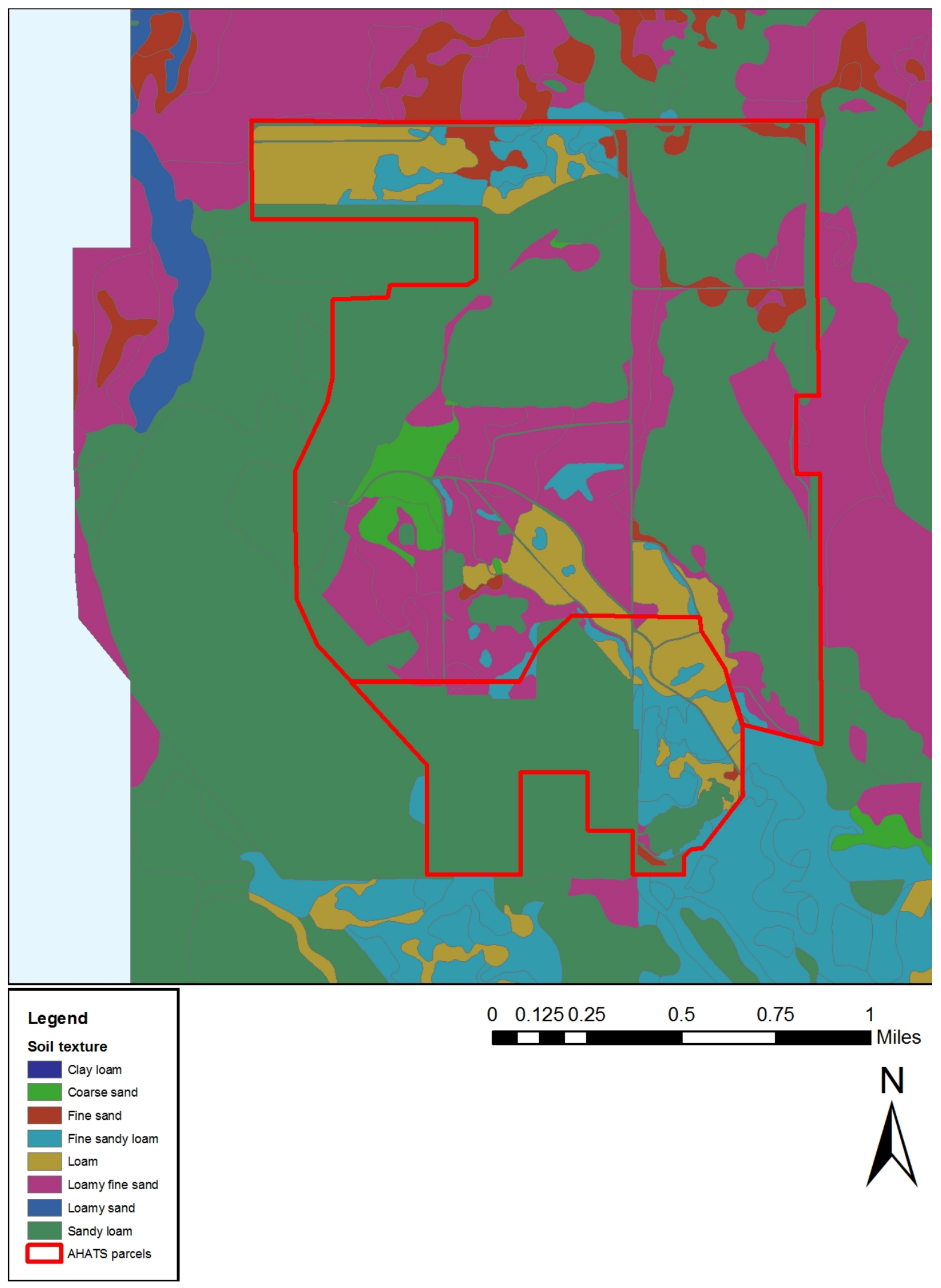

FIGURE 9 Soils in the AHATS Drainage Areas 


\section{TABLE 3 Hydrologic Soil Group Characteristics}

Hydrologic

Soil Group

A

Low runoff potential and high infiltration rates even when thoroughly wetted. They consist chiefly of deep, well to excessively drained sand or gravel and have a high rate of water transmission (greater than $0.30 \mathrm{in./h}$ ).

B Moderate infiltration rates when thoroughly wetted. They consist chiefly of deep to moderately deep, well to moderately well drained soils with moderately fine to moderately coarse textures. These soils have a moderate rate of water transmission ( 0.15 to $0.30 \mathrm{in} . / \mathrm{h})$.

C Low infiltration rates when thoroughly wetted. They consist chiefly of soils with a layer that impedes downward movement of water and soils with a fine to moderately fine texture. These soils have a low rate of water transmission ( 0.05 to $0.15 \mathrm{in} . / \mathrm{h})$.

D High runoff potential and very low infiltration rates when thoroughly wetted. They consist chiefly of clay soils with a high swelling potential, soils with a permanent high water table, soils with a claypan or clay layer at or near the surface, and shallow soils over nearly impervious material. These soils have a very low rate of water transmission ( 0 to $0.05 \mathrm{in} . / \mathrm{h}$ ).

Source: USDA (1986) 


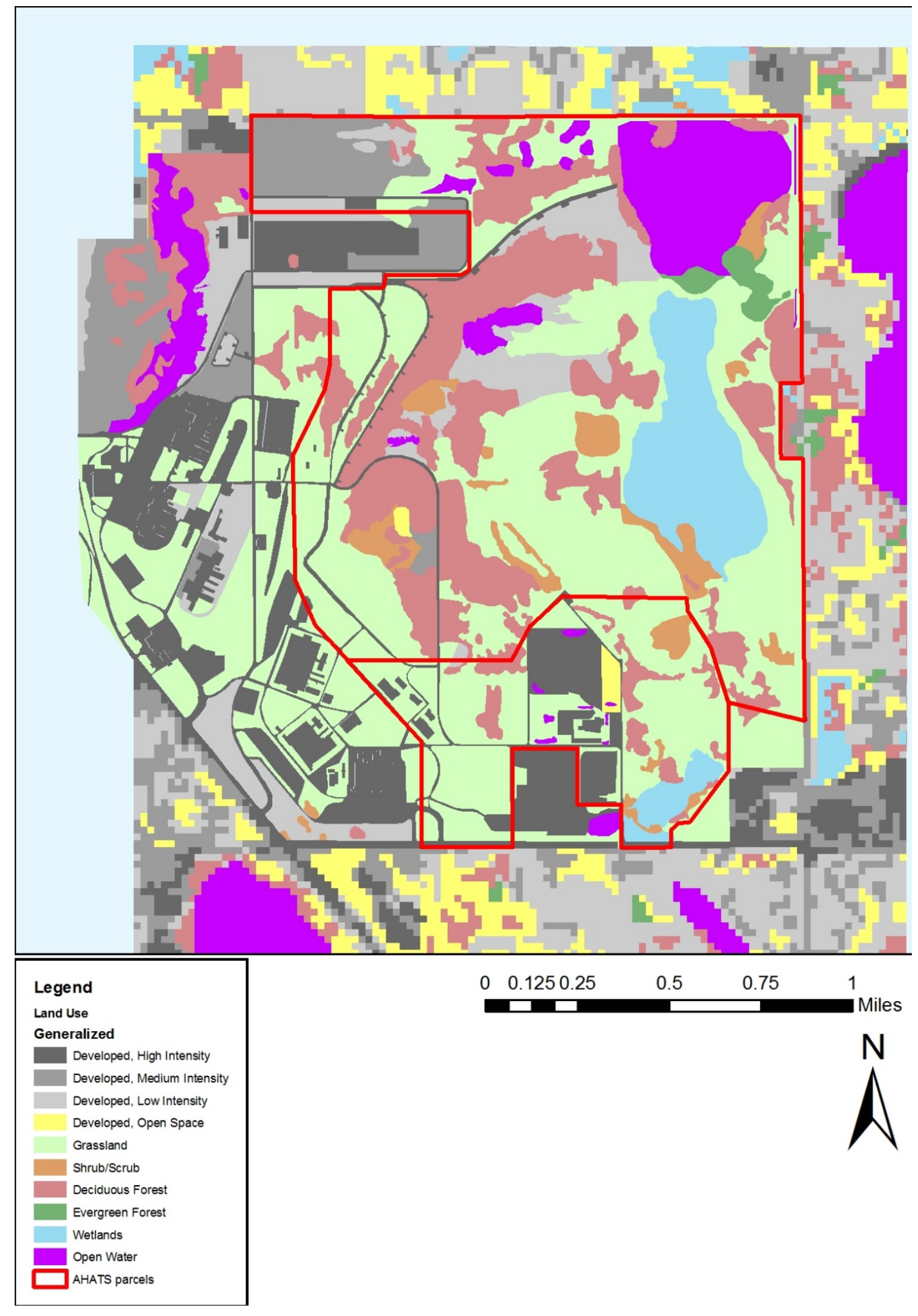

FIGURE 10 Land Use Categories for the AHATS Drainage Areas 


\section{TABLE 4 Curve Numbers Used in TR-55 for Different Land Use Types and Hydrologic Soil Groups}

\begin{tabular}{|c|c|c|c|c|}
\hline \multirow[b]{2}{*}{ Land Cover } & \multicolumn{4}{|c|}{$\begin{array}{l}\text { Curve Number for Each } \\
\text { Hydrologic Soil Group }\end{array}$} \\
\hline & A & $\mathrm{B}$ & $\mathrm{C}$ & $\mathrm{D}$ \\
\hline Open water & 100 & 100 & 100 & 100 \\
\hline Developed, open space & 39 & 61 & 74 & 80 \\
\hline Developed, low intensity & 54 & 70 & 80 & 85 \\
\hline Developed, medium intensity & 81 & 88 & 91 & 93 \\
\hline Developed, high intensity & 98 & 98 & 98 & 98 \\
\hline Barren land & 77 & 86 & 91 & 94 \\
\hline Deciduous forest & 30 & 55 & 70 & 77 \\
\hline Evergreen forest & 36 & 60 & 73 & 79 \\
\hline Shrub/scrub & 43 & 65 & 76 & 82 \\
\hline Herbaceous & 39 & 61 & 74 & 80 \\
\hline Hay/pasture & 49 & 69 & 79 & 84 \\
\hline Cultivated crops & 68 & 79 & 86 & 89 \\
\hline Woody wetlands & 45 & 66 & 77 & 83 \\
\hline Emergent herbaceous wetlands & 78 & 78 & 78 & 78 \\
\hline 4-10\% impervious cover with perennial grasses & 32 & 54 & 67 & 73 \\
\hline 4-10\% impervious cover with perennial grasses and sparse trees & 34 & 56 & 69 & 75 \\
\hline 4-10\% impervious cover with coniferous and/or deciduous shrubs & 36 & 58 & 71 & 77 \\
\hline 11-25\% impervious cover with perennial grasses & 39 & 61 & 74 & 80 \\
\hline $11-25 \%$ impervious cover with perennial grasses and sparse trees & 37 & 59 & 72 & 78 \\
\hline 26-50\% impervious cover with perennial grasses & 49 & 69 & 79 & 84 \\
\hline 51-75\% impervious cover with perennial grasses & 68 & 79 & 86 & 89 \\
\hline 76-90\% impervious cover & 73 & 84 & 91 & 94 \\
\hline 91-100\% impervious cover & 77 & 88 & 95 & 98 \\
\hline Landfill with $0-10 \%$ impervious cover & 77 & 77 & 77 & 77 \\
\hline Buildings and pavement with 76-90\% impervious cover & 76 & 85 & 89 & 91 \\
\hline Buildings and pavement with $91-100 \%$ impervious cover & 83 & 89 & 92 & 93 \\
\hline Buildings with 76-90\% impervious cover & 98 & 98 & 98 & 98 \\
\hline Pavement with 76-90\% impervious cover & 93 & 93 & 93 & 93 \\
\hline Wetland-open water (palustrine) & 85 & 85 & 85 & 85 \\
\hline Permanently flooded littoral aquatic bed & 95 & 95 & 95 & 95 \\
\hline Wet prairie & 80 & 80 & 80 & 80 \\
\hline Slow-moving linear open water habitat & 98 & 98 & 98 & 98 \\
\hline Sand and gravel pits with $0-10 \%$ impervious cover & 77 & 86 & 91 & 94 \\
\hline Grassland with sparse deciduous trees & 39 & 61 & 74 & 80 \\
\hline Grassland with sparse tree layer & 39 & 61 & 74 & 80 \\
\hline Grassland or emergent vegetation & 49 & 69 & 79 & 84 \\
\hline Short grasses with sparse tree cover on upland soils & 43 & 65 & 76 & 82 \\
\hline Short grasses on upland soils & 43 & 65 & 76 & 82 \\
\hline Shrubland & 43 & 65 & 76 & 82 \\
\hline Upland deciduous forest & 32 & 58 & 72 & 79 \\
\hline Upland deciduous woodland & 30 & 55 & 70 & 77 \\
\hline Coniferous woodland & 32 & 58 & 72 & 79 \\
\hline
\end{tabular}

Source: USDA (1986) 


\subsubsection{Time of Concentration}

Another factor that will affect the maximum runoff within a basin is called the time of concentration $\left(T_{c}\right)$. It is the time it takes for the flow to travel from the most distant point of the watershed to the outlet. The speed of the runoff will increase as the various dendritic flow paths converge toward the outlet. Therefore, the time it takes to travel a specified distance will decrease the closer the path gets to the outlet. Segmenting the $T_{C}$ path into smaller pieces with their own travel times $\left(T_{t}\right)$ creates a more accurate $T_{c}$. The $T_{C}$ is then calculated by summing the segments:

$$
T_{c}=T_{t 1}+T_{t 2}+\cdots T_{t m}
$$

where $T_{t}$ is the travel time in hours of the different flow segments, $m$.

There are three $T_{t}$ calculation equations designed specifically for the TR-55 model: sheet flow, shallow concentrated flow, and open channel. Due to the lack of open channels at the AHATS, flow is assumed to travel as either sheet flow or shallow concentrated flow in this analysis.

The sheet, or overland, flow is the flow over plane surfaces. Since sheet flow generally occurs for a few hundred feet before enough water converges for it to become a concentrated flow, the TR-55 method sets the maximum distance for sheet flow at $300 \mathrm{ft}$. The sheet flow travel time is calculated by the following equation:

$$
T_{t}=\frac{0.007(n L)^{0.8}}{\left(P_{2}\right)^{0.5} S^{0.4}}
$$

where $n$ is the Manning's roughness coefficient, which relates the vegetation type to the effect on the speed of water (see Table 5); $P_{2}$ is the depth of the 2-year, 24-hour rainfall event (in.); $S$ is the land slope $(\mathrm{ft} / \mathrm{ft})$; and $L$ is the flow length $(\mathrm{ft})$.

Once the overland flow reaches a point of confluence, there will be a more defined path that allows for an increase in flow velocity. Called shallow concentrated flow, the travel time (in hours or h) for these segments is the ratio of flow length to flow velocity and is calculated as follows:

$$
T_{t}=\frac{L}{3600 v}
$$

where $L$ is once again the flow length ( $\mathrm{ft}$ ) and $v$ is the average velocity (ft/s). In Figure 3-1 of USDA (1986), TR-55 has developed relationships to determine the velocity based on the watercourse slope $(\mathrm{ft} / \mathrm{ft})$ and the identification of the path as paved or unpaved.

The different travel times and times of concentration for each subbasin are defined in Appendix A. 


\subsubsection{Precipitation}

The final parameter necessary is the amount of precipitation, $\mathrm{P}$ (in.), for the desired storm event. The rainfall amount is derived from a synthetic storm based on Technical Paper 40 (TP-40) (Hershfield 1961). TP-40 uses several data sources to create sets of precipitation averages for storms of a particular intensity for particular storm durations all across the United States. The Metropolitan Council compared values of the storms calculated by TP-40 to storms calculated on a more local level by several different studies described by Barr Engineering and Metropolitan Council (2001). The local values were comparable to the values presented in TP-40. The Minnesota Stormwater Manual recognizes TP-40 as the key source of information for areas without measured precipitation data.

Four events were modeled: the 1-year, 2-year, 10-year, and 100-year rainstorms. The name of each event describes how frequently an event of a given magnitude or larger can be expected to occur over that time period. The TR-55 model assumes a 24-hour-duration storm. The precipitation for each event can be seen in Table 6 . The final snowmelt is also taken into consideration and is discussed later in this section. Table 7 provides a variety of storm sizes as well as all the stormwater assessments called for by the Minnesota Stormwater Manual and the Rice Creek Watershed District. The State of Minnesota Sustainable Building Guidelines also call for the evaluation of a 100-year storm for design regulations (University of Minnesota 2009).

\subsubsection{Method Calculations}

The TR-55 model uses the following equations to calculate the peak discharge, $q_{p}$ (in cubic feet per second or cfs):

$$
\begin{gathered}
q_{p}=q_{u} * F * Q * A \\
Q=\left(P-I_{a}\right)^{2} /\left(P-I_{a}\right)+(1000 / C N-10)
\end{gathered}
$$

where

$$
\begin{aligned}
& q_{u}=\text { unit peak discharge (mi²/in.), } \\
& F=\text { pond and swamp percentage (\%), } \\
& Q=\text { runoff (in.), } \\
& P=\text { precipitation (in.), } \\
& A=\text { area (mi²), and } \\
& I_{a}=\text { initial abstraction (in.). }
\end{aligned}
$$


TABLE 5 Manning's n Roughness Coefficients

\begin{tabular}{ll}
\hline \multicolumn{1}{c}{ Surface Description } & $\mathrm{n}$ \\
\hline & \\
Short grass, prairie & 0.15 \\
Dense grasses & 0.24 \\
Woods, light underbrush & 0.4 \\
Woods, dense underbrush & 0.8 \\
\hline
\end{tabular}

Source: USDA (1986)

TABLE 6 Estimated Ramsey County

Rainfall Depths for a 24-Hour Storm

Duration for Different Storm Recurrence Intervals

\begin{tabular}{cc}
\hline Storm Recurrence Interval & $\begin{array}{c}\text { Rainfall Depths, } \\
\text { P (in.) }\end{array}$ \\
\hline 1 year & \\
2 years & 2.3 \\
10 years & 2.75 \\
25 years & 4.15 \\
100 years & 4.78 \\
\hline
\end{tabular}

Source: Hershfield (1961) 


\section{TABLE 7 Comparison of Minnesota Stormwater Manual and Rice Creek Watershed District Criteria}

\begin{tabular}{|c|c|c|}
\hline $\begin{array}{c}\text { Stormwater Management } \\
\text { Target } \\
\end{array}$ & $\begin{array}{c}\text { Minnesota Stormwater Manual } \\
\text { Requirements and Criteria }\end{array}$ & Selected Rice Creek Watershed District Regulations \\
\hline Recharge/Infiltration (Vre) & $\begin{array}{l}\text { None required; strongly encouraged through } \\
\text { site design and stormwater credits: } \\
\text { Option } 1 \text { (protect trout streams and other } \\
\text { sensitive receiving waters): Infiltrate excess } \\
\text { pre-project runoff volume up to the 2-year, } \\
\text { 24-hour event. } \\
\text { Option } 2 \text { (mimic annual average recharge rate } \\
\text { for prevailing hydro soil groups present at } \\
\text { development site): This is a function of annual } \\
\text { pre-development recharge for given soil group, } \\
\text { average annual rainfall volume, and amount of } \\
\text { impervious cover. } \\
\text { Option } 3 \text { (Minnesota on-site infiltration of } \\
\text { stormwater requirement): Infiltrate 10-25\% of } \\
\text { runoff volume produced from 2-year, 24-hour } \\
\text { storm depending on land use. }\end{array}$ & $\begin{array}{l}\text { Design criteria-infiltration BMPs: } \\
\text { Rule } 1 \\
\text { Drawdown within } 48 \text { hours or } 72 \text { hours of the end of a storm event, for } \\
\text { surface or subsurface features, respectively. } \\
\text { Rule } 2 \\
\text { BMPs must be sized to infiltrate and/or retain the runoff volume generated } \\
\text { within the contributing area by a 2-year (2.8-in.) storm under the developed } \\
\text { condition; a site with soils classified as Hydrologic Soil Group (HSG) A or } \\
\text { B must meet this standard through infiltration for at least that part of the site } \\
\text { where HSG A or B soil is present. } \\
\text { Rule } 3 \\
\text { For impervious surfaces, other than the net increase that is required to be } \\
\text { treated during particular levels of redevelopment, the standard is the 0.8-in. } \\
\text { event rather than the 2.8-in. (2-year, 24-hour) event. } \\
\text { Rule } 4 \\
\text { Where infiltration is not feasible, filtration is preferred. }\end{array}$ \\
\hline
\end{tabular}




\section{TABLE 7 (Cont.)}

\begin{tabular}{|c|c|c|}
\hline $\begin{array}{c}\text { Stormwater Management } \\
\text { Target }\end{array}$ & $\begin{array}{c}\text { Minnesota Stormwater Manual } \\
\text { Requirements and Criteria }\end{array}$ & Selected Rice Creek Watershed District Regulations \\
\hline Water Quality (Vwq) & $\begin{array}{l}\text { Required; using MPCA sizing Rule } 1 \text { or } 3 \text { : } \\
\text { Rule } 1 \text { (basic pond sizing in regular waters) } \\
\text { Vts }=\mathrm{Vpp}+\mathrm{Vwq} \\
\text { Vpp }=0.5 \text { inch * } \mathrm{A} *(1 / 12) \\
\text { Vwq }=0.5 \text { inch * IC * }(1 / 12) \\
\text { Rule } 2 \text { (sizing for ponds draining to special } \\
\text { waters) } \\
\text { Vts }=\mathrm{Vpp}+\mathrm{Vwq} \\
\text { Vpp }=0.5 \text { inch * } \mathrm{A} *(1 / 12) \\
\text { Vwq }=1.0 \text { inch * IC * }(1 / 12) \\
\text { Rule } 3 \text { (non-pond BMPs located in regular } \\
\text { waters) } \\
\text { Vwq = } 0.5 \text { inch * IC * (1/12) } \\
\text { The minimum pretreatment volume } \\
\text { recommended (not required in Construction } \\
\text { General Permit) to protect non-pond BMPs } \\
\text { from clogging and to increase their longevity is } \\
0.10 \text { watershed-inch } \\
\text { Rule } 4 \text { (non-pond BMPs located in special } \\
\text { water must have additional live storage Vwq) } \\
\text { Vwq = } 1.0 \text { inch * IC * (1/12) }\end{array}$ & \\
\hline
\end{tabular}




\section{TABLE 7 (Cont.)}

\section{Stormwater Management Target}

Minnesota Stormwater Manual Requirements and Criteria

Channel Protection (Vcp) No current state requirement; strongly

recommended:

Provide 24 hours of extended detention for runoff generated from 1-year, 24-hour storm; store this and gradually release it over 24 hours so that critical erosive velocities in downstream channels are not exceeded over the storm hydrograph; storage capacity necessary is about $60-65 \%$ of the 1 -year storm runoff volume.

Required in most localities; peak discharge control:

Runoff from the 10-year and/or 25-year, 24-hour storms must be controlled to predevelopment rates. (Control of the 10-year flood provides $70-80 \%$ of the protection as the 25-year flood; 10 -year is adequate in most situations.) 


\section{TABLE 7 (Cont.)}

\begin{tabular}{cc}
\hline & \\
$\begin{array}{c}\text { Stormwater Management } \\
\text { Target }\end{array}$ & Minnesota Stormwater Manual \\
Requirements and Criteria & Selected Rice Creek Watershed District Regulations \\
\hline
\end{tabular}

Extreme Storm (Vp100)
Peak discharge control; waived if development is excluded from 100-year floodplain or if control is not needed:

\section{Rule 1}

BMPs must provide safe overflow for 100-year peak discharge even if extreme storm control is not required at site; goal is protection of

100-year floodplain boundaries

(pre-development).

\section{Rule 2}

Control post-development 100-year, 24-hour peak flow rate to local pre-development levels.
Stormwater Management

Plan Modeling

Requirements

\section{Proposed Development Criteria:}

Stormwater runoff rates for the proposed project at the site boundary, in aggregate, must not exceed existing runoff rates for the critical 2-year and 100 -year frequency events. Any increase in a critical event rate at a specific point of discharge from the site must be limited and cause no adverse downgradient impact.
Proposed Development Criteria:

$\underline{\text { Rule } 1}$

The post-development peak rates of runoff must be less than or equal to existing rates.

$\underline{\text { Rule } 2}$

In determining $\mathrm{CNs}$ to model runoff in the post-development condition, the HSG of areas within construction limits is to be shifted down one classification (or one-half classification for HSG A) to account for the impacts of grading on soil structure, unless the project specifications incorporate soil amendments in accordance with District Soil Amendment Guidelines. 


\section{TABLE 7 (Cont.)}

\begin{tabular}{ll}
$\begin{array}{l}\text { Stormwater Management } \\
\text { Target }\end{array}$ & $\begin{array}{c}\text { Minnesota Stormwater Manual } \\
\text { Requirements and Criteria }\end{array}$ \\
\hline $\begin{array}{l}\text { Stormwater Management } \\
\text { Plan Modeling } \\
\text { Requirements (Cont.) }\end{array}$ & $\begin{array}{l}\text { Rule } 3 \\
\text { The 100-year critical event analysis of flood levels, storage volumes, and } \\
\text { flow rates for water bodies and stormwater management basins must include } \\
\text { both the 24-hour rainfall and the 10-day snowmelt events. The 10-day } \\
\text { snowmelt event is simulated by a 7.2-inch, 10-day spring runoff event } \\
\text { during which it is assumed the ground is frozen solid and no infiltration } \\
\text { occurs (i.e., CN is set to 100 for all areas). }\end{array}$ \\
\hline
\end{tabular}

Sources: MPCA (2008); RCWD (2008) 
The unit peak discharge for NRCS type II rainfall distribution is determined by a relationship of the time of concentration (in hours) and $I_{a} / P$. This graph is Exhibit 4-II in the TR-55 manual (USDA 1986). The initial abstraction is defined as the amount of water (in inches) that will infiltrate into the soil or evaporate from the surface at the start of a rainfall event, before additional precipitation becomes runoff or overland flow. The initial abstraction $\left(I_{a}\right)$ is based directly on the CNs.

$$
I_{a}=\left(\frac{1000}{C N}-10\right) * 0.2
$$

The pond and swamp percentage $(F)$ alters the equation to take into account areas where already-saturated ground will not infiltrate. There are several ponds and wetland areas on site, so this is a necessary adjustment to these calculations. (See Table 8.) The peak discharge $\left(q_{p}\right)$ can be expanded by a distribution from NRCS to produce a hydrograph over the 24-hour event. The rainfall distribution type for the AHATS site was chosen to be type II, as suggested for the entire state in the Minnesota Stormwater Manual (MPCA 2008). The rainfall distribution types are described in the TR-55 manual, Appendix B (USDA 1986).

TABLE 8 Proportion of Pond and Swamp Area in Each Basin

\begin{tabular}{rc}
\hline Basin & $\begin{array}{c}\text { Pond and Swamp Area } \\
\text { in Basin (\%) }\end{array}$ \\
\hline & \\
2 & 0 \\
3 & 0 \\
4 & 0 \\
5 & 2.8 \\
6 & 0 \\
7 & 3.65 \\
8 & 0 \\
9 & 11.9 \\
10 & 0.81 \\
11 & 32.71 \\
12 & 2.17 \\
13 & 10.41 \\
14 & 0 \\
15 & 2.69 \\
\hline
\end{tabular}




\subsection{SECOND MODEL (CURRENT CONDITIONS)}

Up to this point, all design considerations have been for the AHATS property as it was before Phase 1 construction began. A second model was created to assess runoff entering and exiting the property at "current conditions," defined to be after the AHRC and FMS site constructions, as it is designed to be once the FMS site is complete.

\subsubsection{Watersheds upon Completion of the FMS Site}

To create a DEM that accounts for the new cantonment construction, the 2-ft LIDAR contour line set was merged with elevation contours derived from digitized design drawings of the AHATS FMS site provided by MNARNG dated May 10, 2010. The basins are defined exactly the same as the preconstruction basins, with the same considerations except for the subbasin containing the FMS site. A detention pond with no outgoing flow is planned for the FMS site; therefore, the subbasin draining this area (10B) is split into two subbasins: the portion of the original Subbasin 15B, and the new Subbasin 16B. AHRC site contours are not included due to a lack of elevation contours. Although the AHRC storm flow direction and drainage path remains relatively the same before and after construction, the slope change on the site may not be accounted for from the missing AHRC elevation data. The resulting watersheds are in Figure 6.

\subsubsection{Approach for Simulating Stormwater upon Completion of the FMS Site}

The same TR-55 method is used for the current conditions model. To account for the construction, land use parameters were updated to reflect the change in landscaping for the AHRC and FMS sites. Areas for parking, buildings, and new grass replaced the preconstruction land use areas. The newer construction also includes the stormwater management techniques of using bioretention ponds. Two such ponds are planned for the FMS site, and five are planned for the AHRC site. The bioretention ponds were accounted for in the model by assigning a very permeable $\mathrm{CN}$ to their areas. The CNs were then averaged, just as they were in the previous model. The other parameter affected by construction is the time of concentration. The $T_{C}$ path for Basin 15B was the same as that for Basin 10B from the previous model because the longest flowpath does not go through the AHRC site. With the creation of Basin 16B, however, a new $T_{C}$ was created, with travel times reflecting the new flow over impervious areas. See Appendix A for the travel times of Basins 15B and 16B.

\subsection{MODEL RESULTS}

The AHATS terrain is mostly open space, with sparse tree cover and small paved or gravel roads, allowing much of the surface flow to follow natural paths. The majority of drainage leaving the site is found in two locations, both of which eventually drain to Rice Creek, which runs along the northwest edge of the property. With the exception of two localized depressions in the interior of the property, the west side drains at a location northeast of D Street and 
Moundsview Boulevard. The east end of the property slopes north through the Marsden Marsh wetlands and drains via the culvert under East Patrol Road. There is some slight drainage from off site under Lexington Road at two locations, as well as overflow from the detention pond of the Ramsey County Public Works site into Sunfish Lake. Outlets were also placed in the model to evaluate the flow at the detention basins to the west of the AHRC site and the basin that overflows into Sunfish.

A total of 14 subbasins (1B to 14B) were delineated for the preconstruction model (Figure 5). For the current conditions model, 15 basins were delineated, as basin 10B was divided into basins $15 \mathrm{~B}$ and $16 \mathrm{~B}$ to account for a new detention pond on the FMS site (Figure 6). A list of the basins follows here:

- 1B - Drainage from offsite from the northern culvert under Lexington Avenue to Marsden Marsh (14B);

- 2B - Drainage off the property to the southwest;

- $3 \mathrm{~B}$ - Drainage along western property line to a natural depression just west of the property, eventually draining to Rice Creek;

- $4 \mathrm{~B}$ - Drainage along notable ditches to the west, eventually draining to Rice Creek;

- 5B - Detention Pond draining the offsite Ramsey County Public Works and parking lot, with overflow draining to Sunfish Lake (9B);

- 6B - Detention Pond draining a small area south of Ben Franklin Street;

- 7B - Manmade depression;

- $8 \mathrm{~B}$ - Drainage along Upper and Lower Magazine Roads to the same natural depression as 3B;

- 9B - Drainage to Sunfish Lake;

- $11 \mathrm{~B}$ - Drainage from offsite from the southern culvert under Lexington Avenue (14B);

- 12B - Drainage to a natural depression west of FMS site;

- $13 \mathrm{~B}$ - Drainage along Hamline Avenue North to Marsden Marsh just before the culvert under East Patrol Road (14B);

- $14 \mathrm{~B}$ - Area surrounding Marsden Marsh that drains under East Patrol Road, eventually draining to Rice Creek; 
- 15B - Drainage to Marsden Marsh (14B), containing AHRC site postconstruction (current conditions model only); and

- $16 \mathrm{~B}$ - Area of FMS site that drains to the edge of cantonment (15B) (current conditions model only).

These locations were chosen to quantify offsite drainage entering AHATS, onsite drainage leaving the property at a particular location, or onsite drainage captured in a closed depression. The runoff calculated for each subbasin is summarized in Appendix A for the 1-year, 2-year, 10-year, and 100-year floods. Appendix B illustrates the flow generated by the model for each storm event.

\subsubsection{Detention Ponds}

The detention pond near the intersection of Ben Franklin Street and Federal Road was designed for minimal runoff and does not contribute runoff toward Marsden Marsh because there is no draining structure, according to the Minnesota Army National Guard. On the basis of GIS topographical information, the normal water level is approximately $947 \mathrm{ft}$ amsl in elevation and the surrounding area slopes upward at a slope of about 3 percent for approximately $15 \mathrm{ft}$ before reaching the ground level of $951 \mathrm{ft}$ amsl. The pond and its surrounding slope have the ability to hold a 1-, 2-, or 10-year flood; however, according to this model the volume of runoff from the 100-year flood will spill beyond the retention pond. See Appendix A for Basin 6B volumes.

The off-site detention pond just west of Hamline Avenue drains to Sunfish Lake. The topographical GIS layer did not provide data about the infrastructure and its relative height above the normal water level. The volume into the pond can be calculated on the basis of the model outputs; however, without information on the height of the drainage to the Sunfish Lake structure, an accurate assessment of the rate and volume of overflow cannot be completed. The model conservatively assumes direct flow (i.e., no storage in the off-site detention pond before the water enters Sunfish Lake).

The new detention pond on the FMS site is designed to drain the majority of the new impervious surface to deal with the resulting additional runoff. There are two planned bioretention ponds for the FMS area. The northern bioretention pond is placed before the detention pond for water quality and reduction purposes before draining to the detention pond. Table 9 details the flows into the bioretention pond and the detention pond, as well as the outgoing amount that will contribute to downstream outlets. For an extreme flood (100-year flood), the runoff to the detention pond is larger than the runoff to the bioretention pond that empties into it. In cases of very large amounts of flooding, runoff from water entering the FMS site through culverts along the west may overflow from the conveyance ditch along the site and spill into the detention pond. 


\section{TABLE 9 Runoff Rates for FMS Bioretention and Detention Pond}

\begin{tabular}{lccc}
\hline & $\begin{array}{c}\text { FMS Runoff } \\
\text { to Northern } \\
\text { Bioretention Pond } \\
\text { Event }\end{array}$ & $\begin{array}{c}\text { Designed FMS } \\
\text { Runoff to New } \\
\text { Detention Pond } \\
\text { (cfs) }^{\text {a }}\end{array}$ & $\begin{array}{c}\text { Designed FMS Runoff } \\
\text { Leaving the New } \\
\text { Detention Pond (cfs) }\end{array}$ \\
\hline $\begin{array}{l}\text { 1-Year } \\
\text { (2.30 in., 24-hour) }\end{array}$ & 33.3 & 0 & 0 \\
$\begin{array}{l}\text { 2-Year } \\
\text { (2.80 in., 24-hour) }\end{array}$ & 41.8 & 2.9 & 1.1 \\
$\begin{array}{l}\text { 10-Year } \\
\text { (4.15 in., 24-hour) }\end{array}$ & 64.9 & 53.3 & 6.5 \\
$\begin{array}{l}\text { 100-Year } \\
\text { (5.90 in., 24-hour) }\end{array}$ & 95.0 & & \\
\hline
\end{tabular}

a Source: SRF Consulting Group (2011)

\subsubsection{Model Comparisons}

Although a comprehensive model examines the connectivity of the drainage system on the AHATS property, a result was also obtained for the cantonment development for comparison. To compare peak discharge rates for the pre-Phase 1 conditions and "current conditions," flows were analyzed at the cantonment outlet (outlet for basin 10B for preconstruction and outlet for basin 15B for current conditions) and at the East Patrol outlet. The Phase 1 development sites drain entirely to the east side of the property, altering only the flows through the subbasins that eventually drain at the East Patrol outlet. Table 10 provides the calculated runoff estimates for pre- Phase 1 construction.

Because specific data on the five bioretention basins created as BMPs for the AHRC were unavailable, it was assumed that these ponds were designed to capture $90 \%$ of the volume for a 1-year flood. It was assumed that these basins would then capture most to all of the 1-year flood and overflow during floods having greater magnitudes. To make this estimate, the CN was held constant for the 1-year flood and adjusted to the newly estimated CN (explained in Section 4.4.2), which accounts for the new impervious areas as well as the very pervious bioretention basins. If more detailed data on the bioretention ponds were available, a different method could be applied to incorporate the mechanisms of the bioretention basin that would result in more accurate runoff estimates.

The east-draining cantonment outlet drains Basin 6B, Basin 15B, and the amount produced by the detention pond (Table 11). By comparing Tables 10 and 11, the change in discharge from the area can be determined at the cantonment outlet and at the East Patrol outlet, located along the north edge of AHATS where Marsden Marsh drains north to Rice Creek. For 
the 1-year event, both new sites have BMPs (bioretention) in place to capture runoff for water quality purposes and retention purposes. The resulting additional runoff due to development is an increase of $<3 \%$ from the cantonment outlet. 
TABLE 10 Pre-Phase 1 Runoff Rates (Q) and Volumes as Calculated by TR-55 Tabular Hydrograph Discharge Method

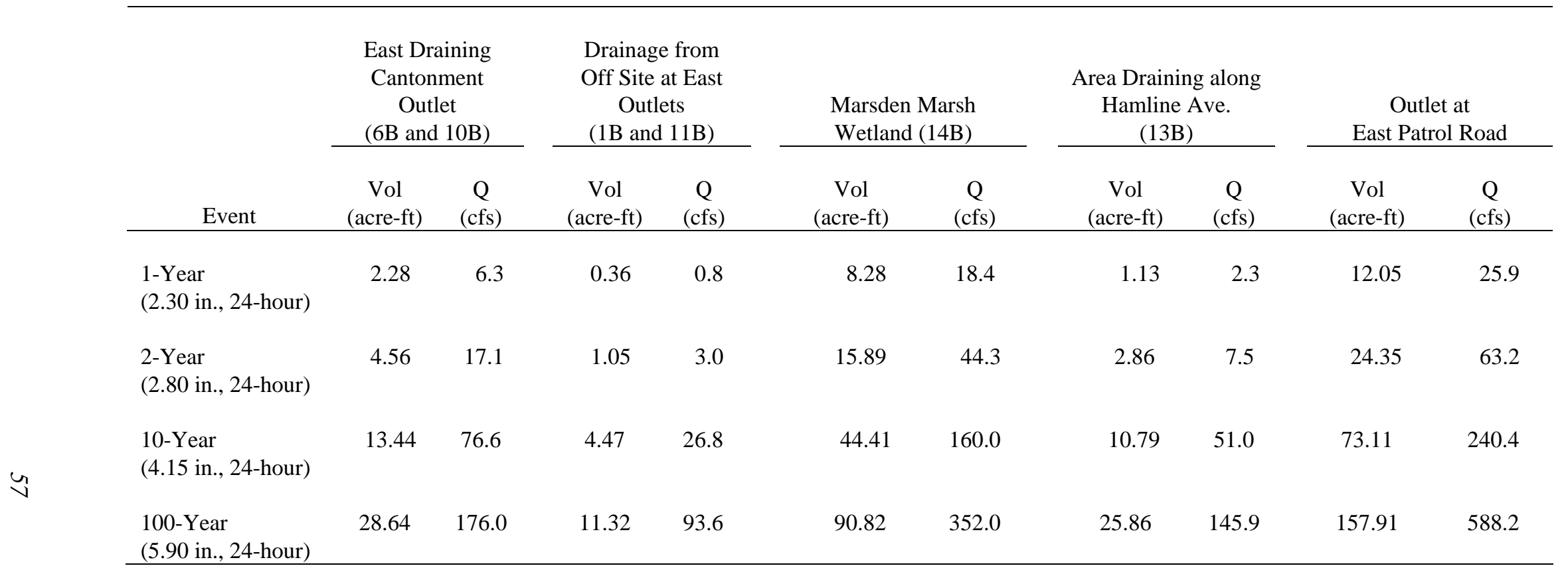


TABLE 11 Post-FMS Runoff Rates (Q) and Volumes as Calculated by TR-55 Tabular Hydrograph Discharge Method

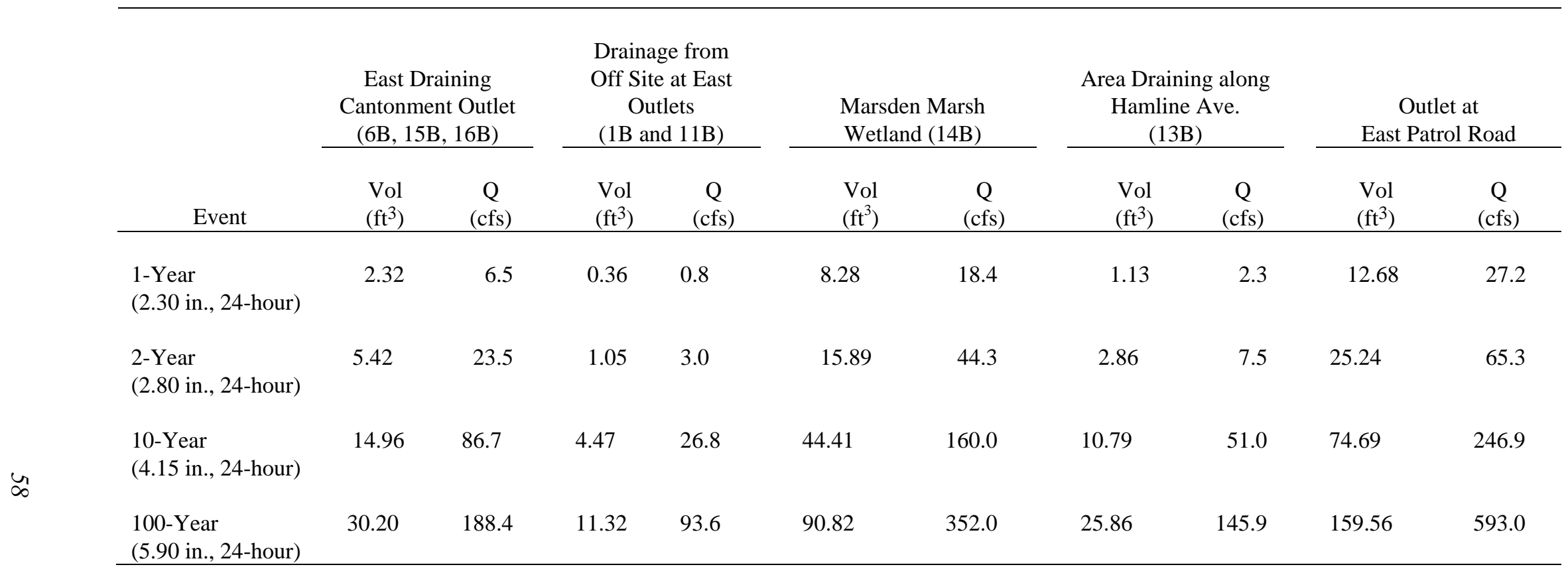




\subsection{SPRING SNOWMELT EVENT}

The synthetic precipitation amounts used to simulate runoff volumes in the model only represent rainfall amounts. Due to Minnesota's climate, snow must also be taken into consideration when designing systems for possible precipitation events. The 100-year, 24-hour rainfall event is generally known as the "extreme" rainstorm and is commonly the worst case scenario used in designs. The intermediate melts throughout the winter generally create less volume and are therefore not a concern. In a situation when snowpack covers the ground but the temperature is warm enough to allow for rain, the combination of the rain and the melting snow will produce large volumes of water. Because this could be a larger concern than the extreme rainfall event, the "spring snowmelt" event is an important calculation for evaluating possible flooding (MPCA 2008).

There are many complications in producing snowpack runoff estimates. The moisture content of the snowpack, the moisture content of the soil at the time the soil froze, snow plowing techniques, sublimation, vegetative cover, and soil properties all affect the rate of snowmelt and are also difficult to approximate (MPCA 2008). Therefore, the Minnesota Stormwater Manual has recommended the method of using a 10-day, 7.2-in. rainstorm event (MPCA 2008). This storm is derived by assuming a 1 ft snowpack with $10 \%$ moisture content (i.e. 12 in. * $0.10=1.2$ in.) is present when a 6-in. rainstorm occurs. Also assuming that the ground is completely frozen and all snow becomes runoff over a period of 10 days, the 7.2-in. rainstorm event with a 10-day distribution can sufficiently represent this "extreme" snowmelt event.

To analyze this 10-day period, the 1-day/10-day principal spillway hydrograph (PSH) method from the National Handbook of Engineering (Snider 1972) is used. This method takes a regionally determined ratio of the known 1-day volume runoff (Q1) to the unknown 10-day volume runoff (Q10). The ratio for the AHATS site is 0.4. Based on this ratio and the time of concentration, a 10-day distribution is determined. Division of the distribution by the subbasin area and the 10-day runoff will create a discharge hydrograph. The peak of this hydrograph is then compared to the rainstorm peak discharges. Table 12 lists this estimated extreme snowmelt runoff along with the 100-year, 24-hour extreme rainfall runoff for comparison. The peak snowmelt runoff is significantly less than the peak rainfall runoff.

\subsection{RUNOFF WATER QUALITY VOLUMES}

\subsubsection{Rainfall}

As the rain from a storm event flows over the surface of land, it will pick up and carry with it pollutants such as oil, road salt, dirt, pesticides, improperly disposed of chemicals and other contaminants and discharge them into streams and lakes with the water. Because most of the contaminants are transported by the flow, the magnitude of the storm is not necessarily proportionally related to water pollution. A storm only has to be long enough to wash the existing chemicals away. This idea is known as the "first flush" and is a design basis for water quality. 
The water quality volume is the volume calculated to design a BMP to treat stormwater. The USEPA Technical Guidance on Implementing (Section 438 of EISA) calls for a water quality design to manage the total volume of rainfall from the $95^{\text {th }}$ percentile storm (rainfall amount that was equaled or exceeded in $95 \%$ of all storm events), or the volume based on a sitespecific hydrologic analysis. A 95\% percentile rainfall depth is used in this report's calculations.

Because there are no onsite gages, data from the closest rain gage in Minneapolis/St. Paul is used. On the basis of rainfall data from 1971-2000, the 95\% percentile storm is approximately 1.5 in. The runoff volumes produced by the model are recorded in Table 13. Note that in basins where the terrain permits high infiltration, little to no runoff may be generated for a precipitation event as small as $1.5 \mathrm{in}$.

\subsubsection{Snowmelt}

Contaminants that have been collecting in snow plowed off roads and parking lots throughout the winter become a concern during the spring melt. For assessing water quality and selecting BMPs, the average snowpack thickness during the average onset date of the snowmelt is used to approximate a runoff volume. The Minnesota Stormwater Manual (MPCA 2008) cites the most appropriate equation to calculate this average snowmelt volume as:

\begin{tabular}{|c|c|c|c|c|c|}
\hline $\begin{array}{c}\text { Average } \\
\text { snowmelt } \\
\text { volume } \\
\text { (depth/unit area) }\end{array}$ & $=$ & $\begin{array}{l}\text { Average snow pack } \\
\text { depth at the } \\
\text { initiation of the } \\
\text { snowmelt period }\end{array}$ & $\mathrm{x}$ & $\begin{array}{l}\text { Typical snow } \\
\text { pack water } \\
\text { equivalent at } \\
\text { time of melt }\end{array}$ & $\begin{array}{l}\text { Estimated } \\
\text { infiltration volume } \\
\text { likely to occur } \\
\text { during a } 10 \text {-day } \\
\text { melt period. }\end{array}$ \\
\hline
\end{tabular}

Based on the typical snowpack water equivalent and snowpack depth, the Minnesota Climatology Working Group, the snowmelt volume for sizing BMPs can be determined. The average snowpack is approximately 6 in. during the typical snowmelt period of March 20 through March 25 at the AHATS location. The group also estimates a typical snowpack water equivalent of $11 \%$ and an infiltration for the 10-day melt period of $0.4 \mathrm{in}$. in northern Ramsey County. The equation becomes:

$$
\begin{aligned}
\text { Average snowmelt volume }= & {[6 \text { in. } \times \text { Area of subbasin } \times 11 \%] } \\
& -[0.4 \text { in. } \times \text { Permeable area of subbasin }]
\end{aligned}
$$

Although this is the standard method suggested by the Minnesota Stormwater Manual, management of the snow in new, relatively large pavement areas will affect this melting event. If snowplows pile the snow directly on impervious surfaces, the amount of runoff will be greater than if the piles were located on nearby permeable surfaces that allow for some infiltration.

Results are compiled in Table 13. Although the 95\% rainfall event (1.5-in.) would be expected to produce more runoff than a 0.66 -in. water equivalent snowmelt event, the frozen ground of the snowmelt allows for only a fraction of the infiltration during a moderate 
temperature rainstorm event. The average snowmelt equation (above) only allows for only 0.4 in. of meltwater to infiltrate permeable areas. Thus, if the permeable area is high, it is likely that more infiltration will occur for the rainfall event, and the snowmelt will produce a greater volume of runoff. This is seen in most of the basins when comparing the two right most columns of Table 13. Note that the non-frozen infiltration rate (related to the curve number, which can be found in Appendix A) will greatly alter the runoff values for the rainfall event between basins even if area and permeability percentage are similar.

In basins with mostly impervious surfaces, model output will be fairly insensitive to whether the ground is frozen. In these basins, the volume of water is greater for the rainstorm event than the snowmelt event because of a larger amount of precipitation. Subbasin 5 is an example of this scenario.

For either the rainfall or snowmelt scenario, the event with the greater volume in a basin becomes the event of concern and is therefore used as the critical design parameter for BMP sizing. Note that for basins $15 \mathrm{~B}$ and $16 \mathrm{~B}$, the stormwater design features result in negligible rainfall volumes for water quality.

\subsection{MODEL FILES}

Because two scenarios were analyzed in this study (scenarios prior to and after AHRC and FMS construction), two sets of WMS Version 8.3 format model files are available. Both sets of files use the same GIS input and overall design. The master file names are:

1. AHATS_SW_Dec_2012 (current conditions upon completion of FMS) and

2. AHATS_SW_preconstruction (for comparison of current results to results prior to construction of AHRC and FMS). 
TABLE 12 Calculated Runoff from the 100-Year, 10-Day Snowmelt Event upon Completion of FMS

\begin{tabular}{|c|c|c|c|c|c|c|}
\hline Basin & $\begin{array}{l}\text { Area } \\
{\left[\mathrm{mi}^{2}\right]}\end{array}$ & $\begin{array}{c}\text { Runoff } \\
\text { Volume } \\
\text { For the 1-day, } \\
\text { 100-yr Storm } \\
\text { (Q1) } \\
\text { [in.] }\end{array}$ & $\begin{array}{l}\text { Ratio of Runoff Volume for the 1- } \\
\text { day Storm to Runoff Volume for } \\
\text { the 10-day Storm } \\
(\mathrm{Q} 1 / \mathrm{Q} 10)\end{array}$ & $\begin{array}{l}\text { Runoff Volume } \\
\text { For a 10-day, } \\
\text { 100-yr (Q10) } \\
\text { [in.] }\end{array}$ & $\begin{array}{l}\text { Peak Discharge for } \\
\text { the Extreme } \\
\text { Snowmelt Event } \\
\text { [cfs] }\end{array}$ & $\begin{array}{c}\text { Peak Discharge for } \\
\text { the Extreme } \\
\text { Rainstorm Event } \\
\text { [cfs] }\end{array}$ \\
\hline 1 & 0.04 & 1.349 & 0.40 & 3.37 & 5.09 & 27.16 \\
\hline 2 & 0.03 & 2.927 & 0.40 & 7.32 & 9.27 & 57.44 \\
\hline 3 & 0.30 & 2.054 & 0.40 & 5.14 & 57.41 & 190.72 \\
\hline 4 & 0.27 & 2.124 & 0.40 & 5.31 & 53.43 & 150.13 \\
\hline 5 & 0.09 & 4.11 & 0.40 & 10.28 & 34.47 & 207.22 \\
\hline 6 & 0.03 & 2.518 & 0.40 & 6.30 & 7.04 & 46.57 \\
\hline 7 & 0.13 & 2.778 & 0.40 & 6.95 & 33.65 & 178.42 \\
\hline 8 & 0.20 & 1.502 & 0.40 & 3.75 & 28.13 & 109.97 \\
\hline 9 & 0.09 & 3.085 & 0.40 & 7.71 & 25.87 & 183.93 \\
\hline 11 & 0.11 & 1.435 & 0.40 & 3.59 & 14.84 & 66.46 \\
\hline 12 & 0.07 & 0.916 & 0.40 & 2.29 & 5.89 & 25.60 \\
\hline 13 & 0.31 & 1.592 & 0.40 & 3.98 & 45.69 & 145.98 \\
\hline 14 & 0.81 & 2.189 & 0.40 & 5.47 & 164.39 & 351.99 \\
\hline 15 & 0.22 & 2.218 & 0.40 & 5.55 & 45.67 & 175.51 \\
\hline 16 & 0.02 & 5.55 & 0.40 & 13.87 & 10.34 & 71.98 \\
\hline
\end{tabular}


TABLE 13 Calculated Water Quality Runoff Volumes upon Completion of FMS

\begin{tabular}{|c|c|c|c|c|c|c|c|c|}
\hline Basin & $\begin{array}{l}\text { Area } \\
{\left[\mathrm{mi}^{2}\right]}\end{array}$ & $\begin{array}{c}\text { Area } \\
\text { [acres] }\end{array}$ & $\begin{array}{c}\text { Percent } \\
\text { Permeabl } \\
\text { e }\end{array}$ & $\begin{array}{c}\text { Permeable } \\
\text { Area } \\
\text { [acres] }\end{array}$ & $\begin{array}{c}\text { Snowpack } \\
\text { Thickness } \\
\text { [in] }\end{array}$ & $\begin{array}{l}\text { Assumed } \\
\text { Water } \\
\text { Equivalency }\end{array}$ & $\begin{array}{c}\text { Rainfall Volumes } \\
\text { for Water Quality } \\
\text { BMP Sizing } \\
\text { [acre-ft] }\end{array}$ & $\begin{array}{l}\text { Snowmelt Volumes } \\
\text { for Water Quality } \\
\text { BMP Sizing } \\
\text { [acre-ft] }\end{array}$ \\
\hline
\end{tabular}

$\begin{array}{lccccccc}0.04 & 25.92 & 0.35 & 9.07 & 6 & 11 \% & 0.015 & 1.12 \\ 0.03 & 21.76 & 0.60 & 13.06 & 6 & 11 \% & 0.210 & 0.76 \\ 0.30 & 192.00 & 0.87 & 167.04 & 6 & 11 \% & 0.224 & 4.99 \\ 0.27 & 172.80 & 0.92 & 158.98 & 6 & 11 \% & 0.274 & 4.20 \\ 0.09 & 57.60 & 0.35 & 20.16 & 6 & 11 \% & 5.698 & 2.50 \\ 0.03 & 19.20 & 0.65 & 12.48 & 6 & 11 \% & 0.746 & 0.64 \\ 0.13 & 83.20 & 0.95 & 79.04 & 6 & 11 \% & 0.402 & 1.94 \\ 0.20 & 128.64 & 0.90 & 115.78 & 6 & 11 \% & 0.986 & 3.22 \\ 0.09 & 57.60 & 0.60 & 34.56 & 6 & 11 \% & 0.005 & 2.02 \\ 0.11 & 71.04 & 0.45 & 31.97 & 6 & 11 \% & 0.852 & 2.84 \\ 0.07 & 44.16 & 0.60 & 26.50 & 6 & 11 \% & 0.096 & 1.55 \\ 0.31 & 197.12 & 0.97 & 191.21 & 6 & 11 \% & 0.049 & 4.47 \\ 0.81 & 515.84 & 0.90 & 464.26 & 6 & 11 \% & 2.149 & 12.90 \\ 0.22 & 141.44 & 0.75 & 106.08 & 6 & 11 \% & 0.000 & 4.24 \\ 0.02 & 12.80 & 0.20 & 2.56 & 6 & 11 \% & 0.025 & 0.62\end{array}$

a The cantonment subbasins are calculated with regard to how conditions will be at the completion of the FMS Site 
This page intentionally left blank 


\section{SUMMARY AND RECOMMENDATIONS}

This purpose of this chapter is to summarize the most restrictive applicable regulations to AHATS stormwater issues, to provide a set of recommendations regarding BMPs for current and future site operations, and to summarize the model and its applications.

\subsection{REGULATORY SITUATION}

Projects involving construction, re-direction of drainage, grading, etc. would be expected to affect the stormwater management at AHATS and would be required to satisfy regulations. Among the various regulations involving stormwater discussed in Chapter 2, the most restrictive are those of the State of Minnesota sustainable building guidelines B3 Project (University of Minnesota 2009) which have been adopted for use at AHATS. Key issues pertaining to stormwater include

- Control runoff to pre-settlement conditions for the 100-year, 24-hour precipitation event,

- No discharge from the site for a 1.25-inch rainfall based on the Rational Method, and

- Capture and treat the runoff from $90 \%$ of the average annual rainfall using BMPs.

The AHATS cantonment runoff including the FMS and AHRC, as modeled in Chapter 4, is demonstrated to meet these B3 runoff goals.

Development at AHATS would require permit application to and approval from a series of governmental units, depending on the nature of the project. A permit for a development exceeding 1 acre would be required from the Rice Creek Water District (RCWD 2012a). Disturbance to wetlands would require a 401 water quality certification from the MPCA and a 404 permit from the U.S. Army Corps of Engineers. Communication and coordination with the City of Arden Hills is recommended regarding the planning for further development (see Table 2); however, the proper use of BMPs and the design features used to satisfy B3 are expected to cause no infractions to the City's MS4 permit.

\subsection{BEST MANAGEMENT PRACTICE RECOMMENDATIONS}

\subsubsection{Inspections, Operations, and Maintenance}

The stormwater system should be inspected periodically. At least annually and after any major storm, culverts and drainageways should be inspected for signs of erosion. Reconstruction and improvement of these features should take place promptly in order to reduce the impact of erosion and turbidity on downstream water quality. 
The sustainable building guidelines (B3) (University of Minnesota 2009) call for cleaning of material deposited in stormwater basins at least twice per year. While actual cleaning may not be necessary, inspections should certainly take place at the cantonment area's bioretention basins at the frequency of twice per year. Considerations for the inspections should include maintenance issues such as stagnant water, water quality, vegetation management, and debris management. The debris may include deposits of organic matter (leaves, algae, etc.), trash, and silt. Removal of debris should take place when site conditions allow.

To continue to satisfy or exceed regulatory requirements and B3, new construction should consider factors to mimic predevelopment hydrology as discussed in Section 3.3. Of these, a key possibility is installation of porous pavement, especially in parking areas. This decision would change perhaps the largest traditionally impervious feature of a new development into a more natural surface in terms of infiltration. The durability of different vendors' materials to freeze-thaw and snowplow blades would need to be considered, as well as cost factors and site-specific soil infiltration information. Vegetated swales along roads and from buildings would also benefit AHATS as a low-cost, low-maintenance option to promote infiltration and treatment of stormwater as it is conveyed toward basins or surface water bodies. These options would also satisfy the spirit of the B3 goals.

\subsubsection{Record Keeping}

The SWMP should be reviewed annually in response to changing site conditions. These may include new or proposed developments, other changes relating to site grading, upgrading of culverts or outlet control structures, changes in regulations at any government level, and the experience with and lessons learned from current stormwater structures and BMPs.

\subsubsection{Key BMPs Recommended for AHATS}

Chapter 3 summarizes many BMPs based mainly on MPCA (2012c) and RCWD (2012c). The key BMPs relevant to AHATS operations are described here.

\section{Erosion, Infiltration, and Water Quality}

The condition and age of culverts should be inspected periodically. Damaged or collapsed culverts should be replaced. Replacement culverts should avoid corrugated pipe to limit mosquito reproduction. The intake and discharge channels should be inspected for erosion effects with consideration for emplacing new or additional erosion protection.

To promote surface water quality, bare and/or sloping soil surfaces should be addressed by establishing vegetation in order to reduce erosion. Such soil surfaces may occur due to construction, training activities, or re-grading in the cantonment or training areas. Construction activities will require development of a set of BMPs for erosion and sediment control, such as the use of silt fencing and other erosion controls, minimization of the amount of disturbed area, and restoration of bare ground with seeding and mulch as soon as feasible. These BMPs would be required under the State construction stormwater permit (MPCA 2009). 
Vehicle mud removal areas should be established, as needed, for vehicles using the training area, in order to collect sediment that would otherwise be distributed on AHATS impervious surfaces.

Landscaping managers should not use excess fertilizer on lawns in the cantonment area. Grass clippings should not be allowed to collect in stormwater basins or on impervious surfaces, as their deposition in basins would result in increased sediment and nutrient loading.

Storm drains in the cantonment area should be marked with painted messages or with plaques to warn against dumping of wastes into the system.

The storage, transfer, and use of fuels, automotive products, and other chemicals should be performed carefully. Any spills or leaks should be addressed promptly to reduce the threat to surface water quality.

\section{Wintertime issues}

Facility managers should avoid the excessive use of road salt as a deicer of roads, parking lots, and sidewalks. The heavier the salt usage, the greater the chloride concentration in onsite natural water bodies and impoundments. Site-specific measurements are required to determine the degree of flushing of such features and whether year-to-year increases are occurring during the non-winter seasons.

Large piles of snow from snow-plowing operations of parking lots should be placed on pervious ground to allow some degree of infiltration.

\section{Mosquitos}

To promote mosquito control, designers should not plan the construction of stormwater basins that would hold stagnant water for more than three days. Designers should use best judgment regarding other design aspects such as edge depth and plant selection, and promote a natural system healthy for mosquito larva predators.

\section{Communication}

Soldiers and other users of the cantonment area and training area should receive instruction regarding stormwater concerns, including whom to contact regarding spills of fuel, automotive products, or other chemicals; observed erosion or flooding; and damage to culverts or other stormwater structures. Online stormwater training is available on the MANG Learning Management System. Indoor signage in cantonment buildings (such as classrooms or meeting rooms) and outdoor signage on roads entering the training area would all serve as opportunities to remind personnel of stormwater concerns. Instruction and signage should include the names of departments and/or individuals to contact with concerns or questions, along with phone numbers or other contact information. 


\subsection{MODEL SUMMARY AND APPLICATION}

The goal of the model was to provide an overall understanding about runoff from storm events on the AHATS property. Delineation of watersheds resulting from future developments and the calculation of runoff produced at the outlets of the basins will allow future construction designs to be evaluated and the best management decisions to be made to avoid damage from flooding and to maintain surface water quality. As additional development is planned or completed for the AHATS cantonment, this model should be updated to assess changes in land use (especially those changes resulting in increased impervious surfaces) and site topography on runoff and storage.

The models could be improved through calibration to field data. Currently, storm flow data associated with rain events at AHATS are not available. If such data were available at key discharge points, the model's parameter values could be adjusted to match the calibration data and thus improve the model's accuracy and ability to analyze future scenarios. Weather station data should be obtained from a nearby source, such as the closest National Oceanic and Atmospheric Administration facility, located in Blaine, Minnesota.

Although onsite contaminant data are not available, runoff quality on a contaminantspecific basis may be evaluated. Many of the modeling programs linked to WMS would allow for these types of calculations. Another future modeling prospect could be to apply the model in the current study as a basis for an analysis with a program such as HEC-HMS (Hydrological Modeling System developed by Hydrologic Engineering Center in U.S. Army Corps of Engineers). This way the bioretention pond mechanisms could be evaluated and the estimate of the runoff they capture could be improved. 


\section{REFERENCES}

Arden Hills, 2006, City of Arden Hills, Minnesota, Storm Water Pollution Prevention Plan (SWPPP) and Permit Application, June 1. Available at http://www.cityofardenhills.org/ DocumentCenter/View/80. Accessed Nov. 12, 2012.

Arden Hills, 2011, City of Arden Hills Chapter 15 Erosion and Sediment Control Ordinance, revised Dec. 22, 2011. Available at http://www.cityofardenhills.org/DocumentCenter/ View/22. Accessed Jan. 3, 2013.

Argonne (Argonne National Laboratory), 1988, Installation Restoration Program: Preliminary Assessment of the Twin Cities Army Ammunition Plant, ANL/EES-LD-2, Argonne, Ill., Feb.

Argonne, 1991, Installation Restoration Program: Remedial Investigation Report for the Twin Cities Army Ammunition Plant (Final Report), ANL/EAIS/LD-6, Argonne, Ill., April.

Barr Engineering Co. and Metropolitan Council, 2001, Urban Small Sites Best Management Practice Manual, July. Available at http://www.metrocouncil.org/environment/water/BMP/ manual.htm. Accessed Jan. 23, 2013.

Clean Water Act, 1972, 33 United States Code § 1251 et seq. Available at http://epw.senate.gov/ water.pdf. Accessed Jan. 3, 2013.

EISA (Energy Independence and Security Act), 2007, Public Law 110-140. Available at http://www.gpo.gov/fdsys/pkg/BILLS-110hr6enr/pdf/BILLS-110hr6enr.pdf. Accessed Nov. 12, 2012.

E.O. (Executive Order) 13514, 2009, Federal Register, Vol. 74, No. 194, Oct. 8. Available at http://www1.eere.energy.gov/femp/pdfs/eo13514.pdf. Accessed Nov. 12, 2012.

EPA (U.S. Environmental Protection Agency), 2009, Technical Guidance on Implementing the Stormwater Runoff Requirements for Federal Projects under Section 438 of the Energy Independence and Security Act, EPA 841-B-09-001. Available at http://www.epa.gov/oaintrnt/ documents/epa_swm_guidance.pdf. Accessed Nov. 12, 2012.

EPA, 2012a, Wetland Regulatory Authority, EPA843-F-04-001. Available at http://water.epa. gov/type/wetlands/outreach/facts_contents.cfm. Accessed Nov. 12, 2012.

EPA, 2012b, Stormwater Phase II Final Rule, Urbanized Areas: Definition and Description, EPA 833-F-00-004, Dec. 1999, revised June 2012. Available at http:/www.epa.gov/npdes/ pubs/fact2-2.pdf. Accessed Nov. 12, 2012.

EPA, 2012c, Region 5 Superfund National Priority List (NPL) Fact Sheet, New Brighton/Arden Hills/TCAAP (U.S. Army), EPA ID\# MN7213820908, last updated Aug. 2012. Available at http://www.epa.gov/reg5sfun/npl/minnesota/MN7213820908.html. Accessed Oct. 22, 2012. 
Global Security, 2012, Twin Cities Army Ammunition Plant. Available at http://www. globalsecurity.org/military/facility/aap-twincities.htm. Accessed Oct. 22, 2012.

Hershfield, D.M., 1961. Rainfall Frequency Atlas of the United States for Durations from 30 Minutes to 24 Hours and Return Periods from 1 to 100 Years, Technical Publication 40, U.S. Weather Bureau.

Jacobs, 2009, Sustainability Master Plan, Arden Hills Army Training Site, Final Report, Sept 8.

Julie Snow Architects Inc., 2011, Pre-Design Report, Infrastructure Improvements at the Arden Hills Army Training Site (AHATS), June 10.

Metropolitan Council, 2010a, Metropolitan Area Master Water Supply Plan, Publication No. 32-09-065, March. Available at http://www.metrocouncil.org/environment/WaterSupply/ masterplan/Masterplan.pdf. Accessed Jan. 23, 2013.

Metropolitan Council, 2010b, Water Resources Management Policy Plan, Publication No. 32-04-065, Sept. 2010. Available at http://www.metrocouncil.org/planning/environment/ WRMPP/WRMPP2005.htm. Accessed Jan. 23, 2013.

Metropolitan Council, 2011, Map of TCAAP Ownership: AHATS Installation \& Cantonment Area, Sept. Available at http://www.metrocouncil.org/media/2011/StadiumReviewAHATSMap. pdf. Accessed Feb. 13, 2013.

Meyer, G.N., et al., 1993, Surficial Geology, Plate 1, Anoka Sand Plain Regional Hydrogeologic Assessment, Minnesota Department of Natural Resources.

MPCA (Minnesota Pollution Control Agency), 2008, Minnesota Stormwater Manual, Version 2, prepared by Minnesota Stormwater Steering Committee, St. Paul, Minn.

MPCA, 2009, Construction Stormwater Permit Overview, February, Available at http://www.pca.state.mn.us/index.php/view-document.html?gid=7386. Accessed April 5, 2013.

MPCA, 2012a, 2012 Impaired Waters List. Available at http://www.pca.state.mn.us/index.php/ water/water-types-and-programs/minnesotas-impaired-waters-and-tmdls/impaired-waterslist.html. Accessed Nov. 12, 2012.

MPCA, 2012b, Managing Dredge Materials in the State of Minnesota, Document No. wq-gen2-01, Sept. Available at http://www.pca.state.mn.us/index.php/view-document. html?gid=12959. Accessed Nov. 12, 2012.

MPCA, 2012c, Minnesota Stormwater Manual, Jan. Available at http://www.pca.state.mn.us/ index.php/view-document.html?gid=8937. Accessed Nov. 12, 2012. 
Patterson, C.J., 1994, “Tunnel Valley Fans of the St. Croix Moraine, East-Central Minnesota, USA,” pp. 69-87 in W.P. Warren and D.G. Croot (editors), Formation and Deformation of Glacial Deposits, A.A. Balkema, Rotterdam, the Netherlands.

Quinn, J.J., 1998, “Tunnel Valleys and Other Glacial Features near Anoka, Minnesota,” pp. 27-34 in C.J. Patterson and H.E. Wright, Jr. (editors), Contributions to the Quaternary of Minnesota: Minnesota Geological Survey Report of Investigations 49, St. Paul, Minn.

RCD (Ramsey County Conservation District), 2012, Wetlands Conservation Act: What Is WCA?. Available at http://www.co.ramsey.mn.us/NR/rdonlyres/25180684-367D-4AB9-B27B1353A6587AE8/29002/wcaforthewebsite.pdf. Accessed Nov. 12, 2012.

RCWD (Rice Creek Watershed District), 2008, Rice Creek Watershed District Rules, Feb. 13. Available at http://www.ricecreek.org/vertical/sites/\%7BF68A5205-A996-4208-96B52C7263C03AA9\%7D/uploads/RCWD_General_Rules_\%28Adopted_02-13-08\%29.pdf. Accessed Nov. 12, 2012.

RCWD, 2012a, Rice Creek Watershed District Permitting Information. Available at http://www.ricecreek.org/index.asp?SEC=\{3EB4B15D-CEF8-4DD4-B72E-74F8B2D8E274\} \&Type=B_BASIC. Accessed Nov. 12, 2012.

RCWD, 2012b, 2010 Watershed Management Plan, Amended January 25, 2012. Available at http://www.ricecreek.org/vertical/Sites/\%7BF68A5205-A996-4208-96B5-2C7263C03AA9\%7D/ uploads/2010_RCWD_Watershed_Management_Plan_Amended_01-25-12.pdf. Accessed Jan. 23, 2013.

RCWD, 2012c, Rice Creek Watershed District Best Management Practices. Available at http://www.ricecreek.org/index.asp?Type=B_BASIC\&SEC=\{A630EEFF-5862-4993-8D7B4B95870921B4\}. Accessed Jan. 23, 2013.

Snider, D. 1972. National Engineering Handbook. Section 4 Hydrology, Chapter 16.

SRF Consulting Group, 2011, MNARNG AHATS Field Maintenance Shop, NGB Project No. 270202, State Project No. 02502.

Stone, J.E., 1966, Surficial Geology of the New Brighton Quadrangle, Minnesota, Geologic Map GM-2, Minnesota Geological Survey.

Tomczik, N., 2013, electronic communication from Tomczik (Permit Coordinator/Wetland Specialist, Rice Creek Watershed District, Blaine, Minn.) to J. Quinn (Argonne National Laboratory, Argonne, Ill.), March 8.

University of Minnesota, 2009, The State of Minnesota Sustainable Building Guidelines (MSBG): Buildings, Benchmarks and Beyond (B3), College of Design. 
U.S. Army Center for Health Promotion and Preventive Medicine, 2004, Tier II Ecological Risk Assessment Report, Twin Cities Army Ammunition Plant, Arden Hills, Minnesota, New Brighton/Arden Hills Superfund Site: Final Report, Dec.

USDA (U.S. Department of Agriculture), 1986, Urban Hydrology for Small Watersheds, Technical Release 55, Natural Resources Conservation Service, Washington, D.C.

USFWS (U.S. Fish and Wildlife Service), 2012, FWS National Wetland Inventory. Available at http://107.20.228.18/Wetlands/WetlandsMapper.html\#. Accessed Nov. 12, 2012.

Wright, H.E., Jr., 1972, “Quaternary History of Minnesota,” pp. 515-547 in P.K. Sims and G.B. Morey (editors), Geology of Minnesota: A Centennial Volume, Minnesota Geological Survey, Minneapolis, Minn.

Wright, H.E., Jr., 1973, “Tunnel Valleys, Glacial Surges and Subglacial Hydrology of the Superior Lobe, Minnesota,” pp. 251-276 in R.F. Black et al. (editors), The Wisconsin Stage, Geological Society of America Memoir 136. 


\section{APPENDIX A:}

MODEL PARAMETERS AND OUTPUTS FOR ALL SUBBASINS BY USING THE TR-55 GRAPHICAL PEAK DISCHARGE METHOD 
This page intentionally left blank 


\section{Report for Basin 1B}

Area $\left(m i^{2}\right)=0.041$

CN

HSG Land Use Description

A Developed, low intensity

A Deciduous forest

\begin{tabular}{lrl} 
CN & Area & CN $\times$ A \\
\hline 54 & 0.009 & 0.501
\end{tabular}

A Developed, medium intensity

$30 \quad 0.001 \quad 0.031$

A Developed, open space

$\begin{array}{lll}81 & 0.001 & 0.107\end{array}$

B Developed, open space

$\begin{array}{lll}39 & 0.003 & 0.098\end{array}$

B Developed, low intensity

$\begin{array}{lll}61 & 0.000 & 0.018\end{array}$

B Developed, medium intensity

$\begin{array}{lll}70 & 0.000 & 0.031\end{array}$

$\begin{array}{lll}88 & 0.000 \quad 0.026\end{array}$

$\mathrm{CN}($ Weighted $)=$ Total Product $\backslash$ Total Area $=53.515$

\begin{tabular}{|c|c|c|c|c|}
\hline \multicolumn{5}{|l|}{$T c$} \\
\hline Type & $\begin{array}{l}\text { Tc } \\
\text { (hr) }\end{array}$ & $\begin{array}{l}\text { Length } \\
(\mathrm{ft})\end{array}$ & $\begin{array}{l}\text { Slope } \\
(\mathrm{ft} / \mathrm{ft})\end{array}$ & Manning's n \\
\hline Sheet flow & 0.303 & 297.771 & 0.045 & 0.15 \\
\hline Conc. flow & 0.028 & 297.401 & 0.033 & \\
\hline Conc. flow & 0.039 & 710.387 & 0.062 & \\
\hline \multicolumn{5}{|c|}{ Tc Total $(\mathrm{hr})=0.370$} \\
\hline \multicolumn{5}{|l|}{$F=0 \%$} \\
\hline \multicolumn{5}{|c|}{ Type II, 24 hour, 1 year } \\
\hline \multicolumn{3}{|c|}{ Runoff $($ in $)=0.034$} & \multicolumn{2}{|c|}{ Peak Discharge $(c f s)=0.100$} \\
\hline \multicolumn{3}{|c|}{ Volume $($ acre $-f t)=0.073$} & \multicolumn{2}{|c|}{ Volume $\left(f t^{3}\right)=3199.046$} \\
\hline \multicolumn{3}{|c|}{ Type II, 24 hour, 2 year $\quad R a$} & \multicolumn{2}{|c|}{$l=2.8$} \\
\hline \multicolumn{3}{|c|}{ Runoff $($ in $)=0.116$} & \multicolumn{2}{|c|}{ Peak Discharge $(c f s)=0.672$} \\
\hline \multicolumn{3}{|c|}{ Volume $($ acre $-f t)=0.251$} & \multicolumn{2}{|c|}{ Volume $\left(f t^{3}\right)=10914.394$} \\
\hline \multicolumn{3}{|c|}{ Type II,24 hour, 10 year $R a$} & \multicolumn{2}{|c|}{$l=4.15$} \\
\hline \multicolumn{3}{|c|}{ Runoff $($ in $)=0.524$} & \multicolumn{2}{|c|}{ Peak Discharge $(c f s)=8.135$} \\
\hline \multicolumn{3}{|c|}{ Volume $($ acre $-f t)=1.132$} & \multicolumn{2}{|c|}{ Volume $\left(f t^{3}\right)=49302.950$} \\
\hline \multicolumn{3}{|c|}{ Type II, 24 hour, 100 year $\quad R a$} & \\
\hline \multicolumn{3}{|c|}{ Runoff $($ in $)=1.349$} & \multicolumn{2}{|c|}{ Peak Discharge $(c f s)=28.311$} \\
\hline \multicolumn{3}{|c|}{ Volume $($ acre $-f t)=2.914$} & \multicolumn{2}{|c|}{ Volume $\left(f t^{3}\right)=126926.870$} \\
\hline
\end{tabular}




\section{Report for Basin 2B}

Area $\left(m i^{2}\right)=0.034$

CN

HSG Land Use Description

\begin{tabular}{lllll} 
& & CN & Area & CN $\times$ A \\
\cline { 3 - 5 } B & Short grasses with sparse tree cover on upland & 65 & 0.024 & 1.530 \\
B & Pavement with 76-90 \% impervious cover & 93 & 0.008 & 0.752
\end{tabular}

CN $($ Weighted $)=$ Total Product $\backslash$ Total Area $=72.1628$

TC

Type Tc

(hr)

Sheet flow 0.277

Concenc. Flow 0.153 Length 298.58 2287.1
Slope

(ft/ft)

0.047

0.067
Manning’s n Paved/Unpaved

0.15

Tc Total (hr) $=0.430$

$F=0 \%$

Type II, 24 hour, 1 year $\quad$ Rainfall $=2.3 "$

Runoff $($ in $)=0.434 \quad$ Peak Discharge $(c f s)=6.554$

Volume $($ acre $-f t)=0.787 \quad$ Volume $\left(f t^{3}\right)=34281.139$

Type II,24 hour, 2 year $\quad$ Rainfall $=2.8 "$

Runoff $($ in $)=0.699 \quad$ Peak Discharge $($ cfs $)=11.623$

Volume $($ acre $-f t)=1.268 \quad$ Volume $\left(f t^{3}\right)=55213.171$

Type II,24 hour, 10 year $\quad$ Rainfall $=4.15 "$

Runoff (in) $=1.577 \quad$ Peak Discharge $(c f s)=28.448$

Volume $($ acre $-f t)=2.860 \quad$ Volume $\left(f t^{3}\right)=124565.338$

Type II,24 hour, 100 year $\quad$ Rainfall $=5.9 "$

Runoff $($ in $)=2.927 \quad$ Peak Discharge $($ cfs $)=55.493$

Volume $($ acre $-f t)=5.308 \quad$ Volume $\left(f t^{3}\right)=231200.218$ 
Report for Basin 3B

Area $\left(m^{2}\right)=0.300$

CN

HSG Land Use Description

B Short grasses on upland soils

B Short grasses with sparse tree cover on upland

\begin{tabular}{lrr} 
& Area & $\mathrm{CN} \times \mathrm{A}$ \\
\hline 65 & 0.032 & 2.050
\end{tabular}

B Pavement with 76-90\% impervious cover

$\begin{array}{lll}65 & 0.106 & 6.873\end{array}$

B Grassland or emergent vegetation

$\begin{array}{lll}93 & 0.027 & 2.534\end{array}$

A Short grasses on upland soils

B Grassland with sparse tree layer

A Upland deciduous woodland

B Upland deciduous woodland

A Grassland with sparse tree layer

$\begin{array}{lll}69 & 0.002 & 0.124\end{array}$

$\begin{array}{lll}43 & 0.002 & 0.092\end{array}$

$\begin{array}{lll}61 & 0.016 & 0.962\end{array}$

$\begin{array}{lll}30 & 0.006 & 0.172\end{array}$

$55 \quad 0.013 \quad 0.710$

$\begin{array}{lll}39 & 0.024 & 0.937\end{array}$

B Buildings with 76-90 \% impervious cover

$\begin{array}{lll}98 & 0.005 & 0.457\end{array}$

B Upland deciduous forest

$\begin{array}{lll}58 & 0.008 & 0.478\end{array}$

B Buildings and pavement with 91-100\%

$\begin{array}{lll}89 & 0.002 & 0.160\end{array}$ impervious cover

B Grassland with sparse deciduous trees

A Pavement with 76-90 \% impervious cover

$\begin{array}{lll}61 & 0.001 & 0.066\end{array}$

A Short grasses with sparse tree cover on upland

$\begin{array}{lll}93 & 0.000 & 0.033\end{array}$

$\begin{array}{lll}43 & 0.003 & 0.108\end{array}$

A Shrubland

$\begin{array}{lll}43 & 0.004 & 0.170\end{array}$

A Upland deciduous forest

$\begin{array}{lll}32 & 0.013 & 0.413\end{array}$

B Shrubland

B Landfill with 0-10\% impervious cover

$\begin{array}{lll}65 & 0.009 & 0.559\end{array}$

A Landfill with 0-10\% impervious cover

A $\quad 26-50 \%$ Impervious cover with perennial grass

$\begin{array}{lll}77 & 0.001 & 0.083\end{array}$

$\begin{array}{lll}77 & 0.000 & 0.028\end{array}$

$\begin{array}{lll}49 & 0.000 & 0.018\end{array}$

CN $($ Weighted $)=$ Total Product $\backslash$ Total Area $=62.4113$

\begin{tabular}{|c|c|c|c|c|c|}
\hline Type & $\begin{array}{l}\text { Tc } \\
\text { (hr) }\end{array}$ & $\begin{array}{l}\text { Length } \\
\text { (ft) }\end{array}$ & $\begin{array}{l}\text { Slope } \\
\text { (ft/ft) }\end{array}$ & Manning's n & Paved/Unpaved \\
\hline Sheet flow & 0.193 & 292.58 & 0.0133 & 0.15 & \\
\hline Concen. Flow & 0.874 & 9656.1 & 0.036 & & Unpaved \\
\hline
\end{tabular}

Tc Total $(\mathrm{hr})=1.067$

$F=0 \%$

$\begin{array}{ccc}\text { Type II, } 24 \text { hour }, 1 \text { year } & \text { Rainfall }= & 2.3^{\prime \prime} \\ \text { Runoff }(\text { in })=0.168 & \text { Peak Discharge }(c f s)=7.039 \\ \text { Volume }(\text { acre }-f t)=2.688 & \text { Volume }\left(f t^{3}\right)=117089.280 \\ \text { Type II, } 24 \text { hour }, 2 \text { year } & \text { Rainfall }= & 2.8^{\prime \prime} \\ \text { Runoff }(\text { in })=0.333 & \text { Peak Discharge }(c f s)=20.111 \\ \text { Volume }(\text { acre }-f t)=5.328 & \text { Volume }\left(f t^{3}\right)=232087.680\end{array}$


Type II, 24 hour, 10 year $\quad$ Rainfall $=4.15 "$

Runoff $($ in $)=0.965 \quad$ Peak Discharge $($ cfs $)=82.038$

Volume $($ acre $-f t)=15.440 \quad$ Volume $\left(f t^{3}\right)=672566.400$

Type II, 24 hour, 100 year $\quad$ Rainfall $=5.9 "$

Runoff (in) $=2.054 \quad$ Peak Discharge $($ cfs $)=190.498$

Volume $($ acre $-f t)=32.864 \quad$ Volume $\left(f t^{3}\right)=1431555.840$ 
Report for Basin 4B

Area $\left(m i^{2}\right)=0.269$

CN

HSG Land Use Description

A Developed, high intensity

A Developed, low intensity

CN Area $\mathrm{CN} \times \mathrm{A}$

$\begin{array}{lll}98 & 0.004 & 0.387\end{array}$

A Upland deciduous forest

$\begin{array}{lll}54 & 0.001 & 0.058\end{array}$

A Open water

$\begin{array}{lll}32 & 0.011 & 0.356\end{array}$

B Open water

$\begin{array}{lll}100 & 0.000 & 0.036\end{array}$

$\begin{array}{lll}100 & 0.005 & 0.467\end{array}$

B Upland deciduous forest

$58 \quad 0.018 \quad 1.021$

B Pavement with 76-90\% impervious cover

$93 \quad 0.014 \quad 1.303$

B 11-25\% Impervious cover with perennial grass

$59 \quad 0.065 \quad 3.815$

B 4-10\% Impervious cover with perennial grass

$54 \quad 0.011 \quad 0.582$

B Sand and gravel pits with $0-10 \%$ impervious cover

$\begin{array}{lll}86 & 0.009 & 0.772\end{array}$

B Grassland with sparse tree layer

B Buildings with 76-90\% impervious cover

$\begin{array}{lll}61 & 0.047 & 2.849\end{array}$

$\begin{array}{lll}98 & 0.001 & 0.070\end{array}$

B 51-75\% Impervious cover with perennial grass

$\begin{array}{lll}79 & 0.005 & 0.397\end{array}$

B 11-25\% Impervious cover with perennial grass

$\begin{array}{lll}61 & 0.026 & 1.600\end{array}$

A Grassland with sparse tree layer

$\begin{array}{lll}39 & 0.005 & 0.196\end{array}$

B Upland deciduous woodland

$\begin{array}{lll}55 & 0.013 & 0.731\end{array}$

B Buildings and pavement with 91-100\% impervious cover

$\begin{array}{lll}89 & 0.003 & 0.288\end{array}$

B Wetland-open water (palustrine)

$\begin{array}{lll}85 & 0.004 & 0.305\end{array}$

CN $($ Weighted $)=$ Total Product $\backslash$ Total Area $=63.2012$

Tc

Type

Tc

Length

Slope

Manning's n Paved/Unpaved

Sheet flow

(hr)

(ft)

(ft/ft)

Concen. Flow

0.437

295.2

0.045

6021.5

0.012

0.24

Unpaved

Tc Total $(\mathrm{hr})=1.377$

$F=2.8 \%$

Type II, 24 hour, 1 year $\quad$ Rainfall $=2.3 "$

Runoff $($ in $)=0.185 \quad$ Peak Discharge $(c f s)=5.020$

Volume $($ acre $-f t)=2.664 \quad$ Volume $\left(f t^{3}\right)=116043.840$

Type II,24 hour, 2 year $\quad$ Rainfall $=2.8$ "

Runoff $($ in $)=0.359 \quad$ Peak Discharge $(c f s)=13.348$

Volume $($ acre $-f t)=5.170 \quad$ Volume $\left(f t^{3}\right)=225187.776$

Type II, 24 hour, 10 year

Rainfall $=4.15^{\prime \prime}$

Runoff $($ in $)=1.012$

Peak Discharge $(c f s)=50.407$ 
Volume $($ acre $-f t)=14.573 \quad$ Volume $\left(f t^{3}\right)=634791.168$

Type II, 24 hour, 100 year $\quad$ Rainfall $=5.9 "$

Runoff $($ in $)=2.124 \quad$ Peak Discharge $($ cfs $)=115.112$

Volume $($ acre $-f t)=30.586 \quad$ Volume $\left(f t^{3}\right)=1332308.736$ 


\section{Report for Basin 5B}

Area $\left(m i^{2}\right)=0.09$

CN

HSG Land Use Description

B Short grasses with sparse tree cover on upland

\begin{tabular}{ccc} 
CN & Area & CN $\times$ A \\
\hline 65 & 0.006 & 0.388 \\
93 & 0.006 & 0.597 \\
88 & 0.007 & 0.644
\end{tabular}

B 91-100 Impervious cover

$\begin{array}{lll}88 & 0.007 & 0.644\end{array}$

B Buildings and pavement with 91-100\% impervious

$\begin{array}{lll}89 & 0.003 & 0.270\end{array}$

B Open water

$\begin{array}{lll}100 & 0.001 & 0.079\end{array}$

CN $($ Weighted $)=$ Total Product $\backslash$ Total Area $=84.0622$

\begin{tabular}{|c|c|c|c|c|}
\hline \multicolumn{5}{|l|}{$T c$} \\
\hline Type & $\begin{array}{l}\text { Tc } \\
(\mathrm{hr})\end{array}$ & $\begin{array}{l}\text { Length } \\
(\mathrm{ft})\end{array}$ & $\begin{array}{l}\text { Slope } \\
(\mathrm{ft} / \mathrm{ft})\end{array}$ & Manning's $n$ \\
\hline Sheet flow & 0.139 & 294.7 & 0.310 & 0.15 \\
\hline Concen. Flow & 0.385 & 2573 & 0.013 & \\
\hline \multicolumn{5}{|c|}{ Tc Total $(\mathrm{hr})=0.524$} \\
\hline \multicolumn{5}{|l|}{$F=3.65 \%$} \\
\hline \multicolumn{5}{|c|}{ Type II, 24 hour, 1 year $\quad$ Rainfall $=2.3 "$} \\
\hline \multicolumn{3}{|c|}{ Runoff $($ in $)=0.967$} & \multicolumn{2}{|c|}{ Peak Discharge $(c f s)=30.882$} \\
\hline \multicolumn{3}{|c|}{ Volume $($ acre $-f t)=4.642$} & \multicolumn{2}{|c|}{ Volume $\left(f t^{3}\right)=202188.1$} \\
\hline \multicolumn{3}{|c|}{ Type II, 24 hour, 2 year Rain } & \multicolumn{2}{|c|}{$=2.8 "$} \\
\hline \multicolumn{3}{|c|}{ Runoff $($ in $)=1.358$} & \multicolumn{2}{|c|}{ Peak Discharge $(c f s)=44.594$} \\
\hline \multicolumn{3}{|c|}{ Volume $($ acre $-f t)=6.518$} & \multicolumn{2}{|c|}{ Volume $\left(f t^{3}\right)=283941.500$} \\
\hline \multicolumn{3}{|c|}{ Type II, 24 hour, 10 year $\quad$ Rai } & \multicolumn{2}{|c|}{$=4.15^{\prime \prime}$} \\
\hline \multicolumn{3}{|c|}{ Runoff $($ in $)=2.509$} & \multicolumn{2}{|c|}{ Peak Discharge $(c f s)=85.926$} \\
\hline \multicolumn{3}{|c|}{ Volume $($ acre $-f t)=12.043$} & \multicolumn{2}{|c|}{ Volume $\left(f t^{3}\right)=524601.800$} \\
\hline \multicolumn{3}{|c|}{ Type II, 24 hour, 100 year $\quad R a$} & \multirow{2}{*}{\multicolumn{2}{|c|}{$\begin{array}{l}l=5.9 " \\
\text { Discharge }(c f s)=144.379\end{array}$}} \\
\hline \multicolumn{3}{|c|}{ Runoff $($ in $)=4.11$} & & \\
\hline \multicolumn{3}{|c|}{ Volume $($ acre $-f t)=19.728$} & \multicolumn{2}{|c|}{ Volume $\left(f t^{3}\right)=859351.700$} \\
\hline
\end{tabular}




\section{Report for Basin 6B}

Area $\left(m i^{2}\right)=0.028$

CN

HSG Land Use Description

B Short grasses with sparse tree cover on upland

\begin{tabular}{ccc}
$\mathrm{CN}$ & Area & $\mathrm{CN} \times \mathrm{A}$ \\
\hline 65 & 0.024 & 1.571 \\
93 & 0.000 & 0.036 \\
88 & 0.003 & 0.274 \\
58 & 0.001 & 0.045
\end{tabular}

B Pavement with 76-90\% impervious cover

B $\quad 91-100 \%$ Impervious cover

B 4-10\% Impervious cover with coniferous

CN $($ Weighted $)=$ Total Product $\backslash$ Total Area $=67.7123$

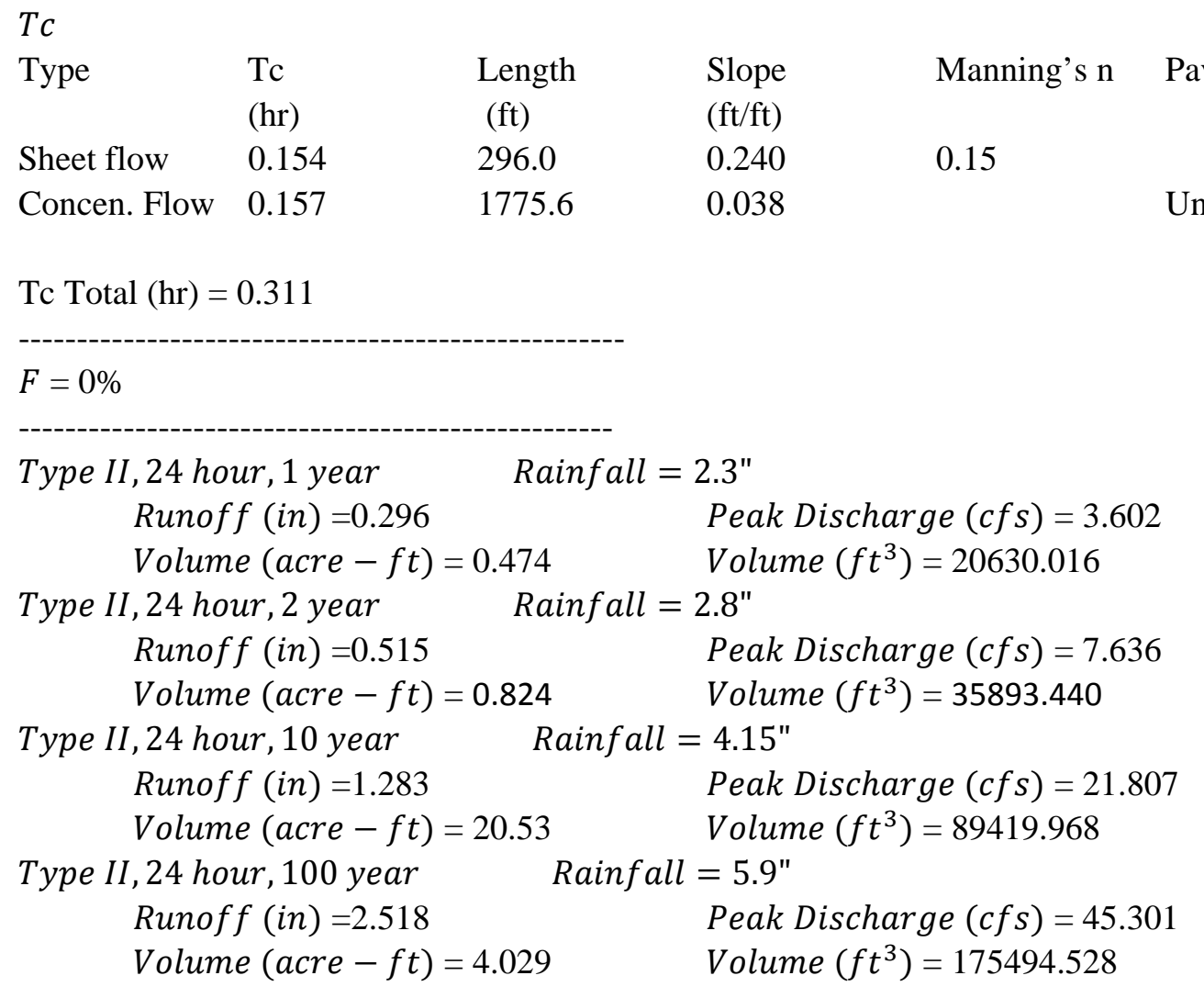




\section{Report for Basin 7B}

Area $\left(m i^{2}\right)=0.126$

CN

HSG Land Use Description

A Upland deciduous woodland

\begin{tabular}{ccc} 
CN & Area & CN $\times$ A \\
\hline 30 & 0.001 & 0.024 \\
43 & 0.001 & 0.034 \\
58 & 0.004 & 0.251 \\
55 & 0.041 & 2.233 \\
65 & 0.001 & 0.077
\end{tabular}

A Shrubland

B Upland deciduous forest

B Upland deciduous woodland

$65-0.001-0.077$

A Sand and gravel pits with $0-10 \%$ impervious cover

$\begin{array}{lll}77 & 0.000 & 0.030\end{array}$

B Sand and gravel pits with $0-10 \%$ $\begin{array}{lrrr}\text { impervious cover } & 86 & 0.033 & 2.847\end{array}$

B Open water

$\begin{array}{lll}100 & 0.014 & 1.419\end{array}$

B Short grasses with sparse tree cover on upland

A Upland deciduous forest

$\begin{array}{lll}65 & 0.030 & 1.973\end{array}$

$\begin{array}{lll}32 & 0.000 & 0.013\end{array}$

CN $($ Weighted $)=$ Total Product $\backslash$ Total Area $=70.5688$

\begin{tabular}{|c|c|c|c|c|c|}
\hline \multicolumn{6}{|l|}{$T c$} \\
\hline Type & $\begin{array}{l}\text { Tc } \\
\text { (hr) }\end{array}$ & $\begin{array}{l}\text { Length } \\
\text { (ft) }\end{array}$ & $\begin{array}{l}\text { Slope } \\
\text { (ft/ft) }\end{array}$ & Manning's n & Paved/Unpaved \\
\hline Sheet flow & 0.458 & 292.9 & 0.439 & 0.8 & \\
\hline Concen. Flow & 0.035 & 1408 & 0.469 & & Unpaved \\
\hline \multicolumn{6}{|c|}{ Tc Total (hr) $=0.493$} \\
\hline \multicolumn{6}{|l|}{$F=11.90 \%$} \\
\hline \multicolumn{6}{|c|}{ Type II, 24 hour, 1 year $\quad$ Rainfall $=2.3 "$} \\
\hline \multicolumn{3}{|c|}{ Runoff $($ in $)=0.381$} & \multicolumn{3}{|c|}{ Peak Discharge $(c f s)=12.357$} \\
\hline \multicolumn{3}{|c|}{ Volume $($ acre $-f t)=2.642$} & \multicolumn{3}{|c|}{ Volume $\left(f t^{3}\right)=115068.096$} \\
\hline \multicolumn{3}{|c|}{ Type II, 24 hour, 2 year Rain } & \multicolumn{3}{|c|}{$2.8^{\prime \prime}$} \\
\hline \multicolumn{3}{|c|}{ Runoff $($ in $)=0.630$} & \multicolumn{3}{|c|}{ Peak Discharge $(c f s)=23.496$} \\
\hline \multicolumn{3}{|c|}{ Volume $($ acre $-f t)=4.368$} & \multicolumn{3}{|c|}{ Volume $\left(f t^{3}\right)=190270.080$} \\
\hline \multicolumn{3}{|c|}{ Type II, 24 hour, 10 year $R a$} & $=4.15^{\prime \prime}$ & & \\
\hline \multicolumn{3}{|c|}{ Runoff $($ in $)=1.469$} & \multicolumn{3}{|c|}{ Peak Discharge $(c f s)=59.983$} \\
\hline \multicolumn{3}{|c|}{ Volume $($ acre $-f t)=10.185$} & \multicolumn{3}{|c|}{ Volume $\left(f t^{3}\right)=443661.504$} \\
\hline \multicolumn{3}{|c|}{ Type II, 24 hour, 100 year $\quad R a$} & $=5.9 "$ & & \\
\hline \multicolumn{3}{|c|}{ Runoff $($ in $)=2.778$} & \\
\hline Volun & $e(\operatorname{acre}-f t)$ & 19.261 & \multicolumn{3}{|c|}{$\begin{array}{l}\text { Peak Discharge }(c f s)=119.9 / 7 \\
\text { Volume }\left(f^{3}\right)=839000.448\end{array}$} \\
\hline
\end{tabular}


Report for Basin 8B

Area $\left(m i^{2}\right)=0.201$

CN

HSG Land Use Description

A Upland deciduous forest

B Short grasses on upland soils

B Upland deciduous forest

B Grassland with sparse deciduous trees

B Buildings and pavement with 91-100\% impervious cover

\begin{tabular}{ccc}
$\mathrm{CN}$ & Area & $\mathrm{CN} \times \mathrm{A}$ \\
\hline 32 & 0.017 & 0.552
\end{tabular}

$\begin{array}{lll}65 & 0.012 & 0.756\end{array}$

$\begin{array}{lll}58 & 0.010 & 0.558\end{array}$

$\begin{array}{lll}61 & 0.028 & 1.737\end{array}$

B Upland deciduous woodland

$\begin{array}{lll}89 & 0.008 & 0.678\end{array}$

$\begin{array}{lll}55 & 0.059 & 3.243\end{array}$

B Pavement with 76-90\% impervious cover

$\begin{array}{lll}93 & 0.009 & 0.858\end{array}$

A Upland deciduous woodland

$\begin{array}{lll}30 & 0.028 & 0.830\end{array}$

B Grassland with sparse tree layer

$\begin{array}{lll}61 & 0.003 & 0.171\end{array}$

B 4to 10\% Impervious cover with perennial grass

A Sand and gravel pits with $0-10 \%$ impervious cover

$\begin{array}{lll}54 & 0.000 & 0.022\end{array}$

A Open water

A Shrubland

B Landfill with 0-10\% impervious cover

B Sand and gravel pits with $0-10 \%$ impervious cover

$\begin{array}{lll}77 & 0.008 & 0.618\end{array}$

$\begin{array}{lll}100 & 0.002 & 0.160\end{array}$

$\begin{array}{lll}43 & 0.007 & 0.310\end{array}$

$\begin{array}{lll}77 & 0.001 & 0.062\end{array}$

$\begin{array}{lll}86 & 0.001 & 0.069\end{array}$

$\begin{array}{lll}76 & 0.001 & 0.061\end{array}$

C Short grasses with sparse tree cover on upland

$\begin{array}{lll}65 & 0.003 & 0.183\end{array}$

B Short grasses with sparse tree cover on upland

$\begin{array}{lll}70 & 0.001 & 0.084\end{array}$

C Upland deciduous woodland

$\begin{array}{lll}56 & 0.003 & 0.157\end{array}$

B 4-10\% Impervious cover with perennial grass

$\begin{array}{lll}34 & 0.001 & 0.027\end{array}$

A $\quad 4-10 \%$ Impervious cover with perennial grass

$\mathrm{CN}($ Weighted $)=$ Total Product $\backslash$ Total Area $=55.534$

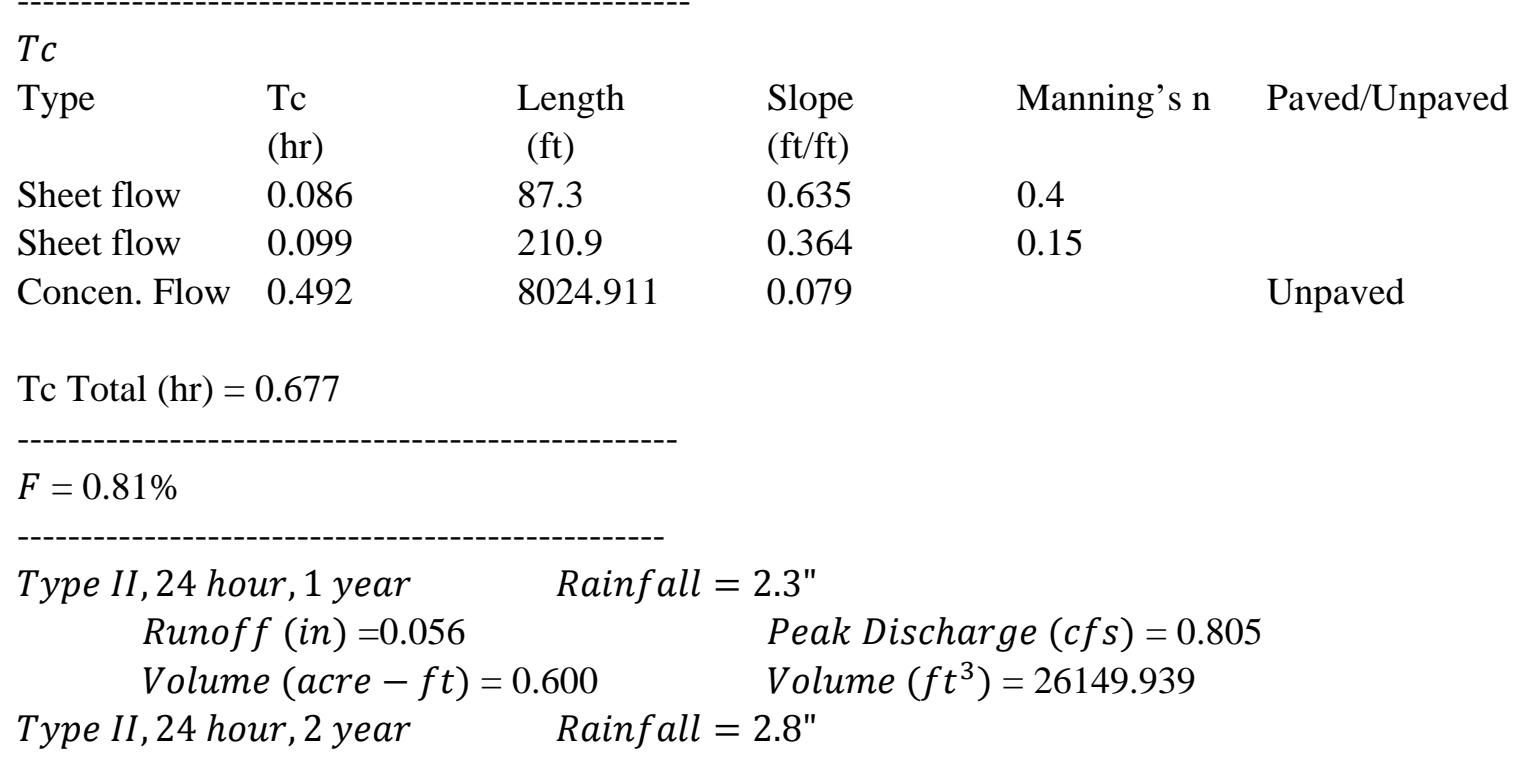




$$
\begin{array}{ll}
\text { Runoff }(\text { in })=0.156 & \text { Peak Discharge }(c f s)=3.936 \\
\text { Volume }(\text { acre }-f t)=1.672 & \text { Volume }\left(f t^{3}\right)=72846.259
\end{array}
$$

Type II,24 hour, 10 year $\quad$ Rainfall $=4.15 "$

Runoff $($ in $)=0.615 \quad$ Peak Discharge $(c f s)=33.307$

Volume $($ acre $-f t)=6.593 \quad$ Volume $\left(f t^{3}\right)=287182.368$

Type II, 24 hour, 100 year $\quad$ Rainfall $=5.9 "$

Runoff (in) $=1.502 \quad$ Peak Discharge $($ cfs $)=102.246$

Volume $($ acre $-f t)=16.101 \quad$ Volume $\left(f t^{3}\right)=701378.726$ 
Report for Basin 9B

Area $\left(m i^{2}\right)=0.09$

CN

HSG Land Use Description

B Short grasses with sparse tree cover on upland

\begin{tabular}{rcc} 
CN & Area & CN $\times$ A \\
\hline 65 & 0.055 & 3.576 \\
93 & 0.010 & 0.919 \\
88 & 0.001 & 0.113 \\
100 & 0.004 & 0.430 \\
43 & 0.002 & 0.074 \\
65 & 0.005 & 0.335 \\
80 & 0.002 & 0.172 \\
80 & 0.003 & 0.241 \\
95 & 0.024 & 2.245 \\
61 & 0.001 & 0.052 \\
58 & 0.002 & 0.125 \\
55 & 0.005 & 0.284 \\
30 & 0.000 & 0.013 \\
43 & 0.000 & 0.018
\end{tabular}

B Pavement with 76-90 \% impervious cover

B $91-100 \%$ Impervious cover

B Open water

A Shrubland

B Shrubland

A Wet prairie

B Wet prairie

B Permanently flooded littoral aquatic bed

B Grassland with sparse tree layer

B Upland deciduous forest

B Upland deciduous woodland

A Upland deciduous woodland

A Short grasses with sparse tree cover on upland

CN $($ Weighted $)=$ Total Product $\backslash$ Total Area $=74.6455$

Tc

Type Tc

(hr)

Sheet flow $\quad 0.218$

Concenc. Flow 0.120
Length

(ft)

298.3

1251.3
Slope

$(\mathrm{ft} / \mathrm{ft})$

0.102

0.032
Manning’s n Paved/Unpaved

0.15

Unpaved

Tc Total $(\mathrm{hr})=0.338$

$F=32.71 \%$

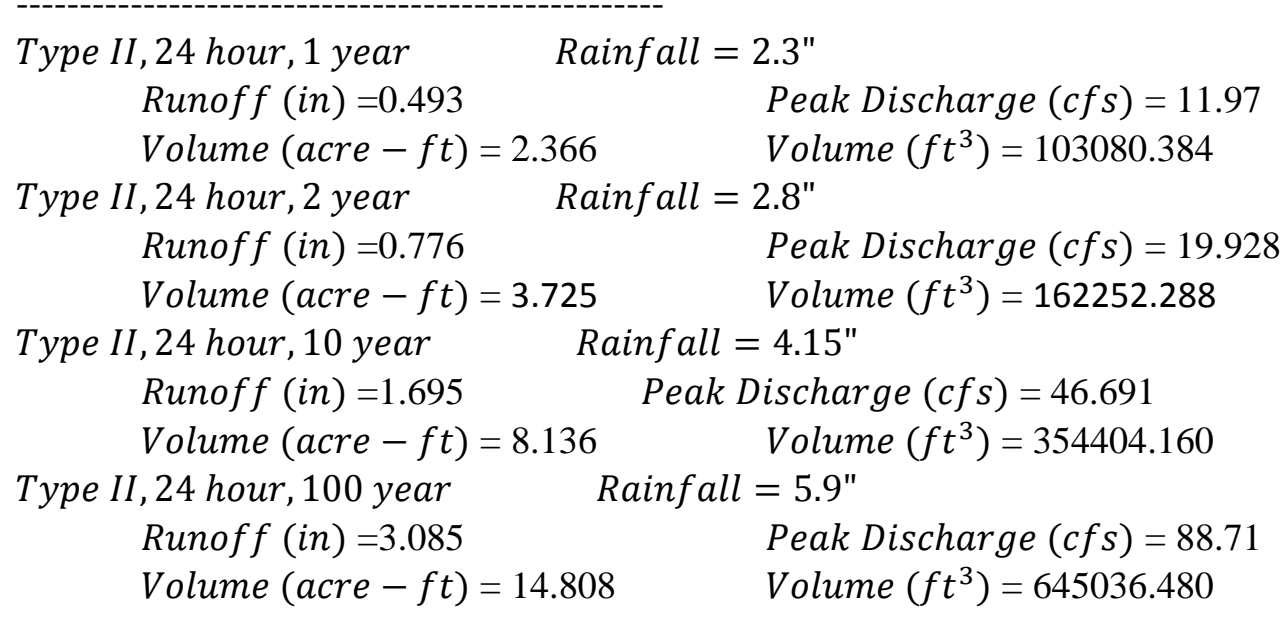




\begin{tabular}{llll} 
Report for Basin 11B & & & \\
\hline Area $\left(m i^{2}\right)=0.11$ & & & \\
CN & & & \\
HSG Land Use Description & CN & Area & CN × A \\
B Short grasses with sparse tree cover on upland & 65 & 0.001 & 0.052 \\
A Developed, Low Intensity & 54 & 0.032 & 1.707 \\
A Developed, Medium Intensity & 81 & 0.012 & 0.972 \\
B Developed, Medium Intensity & 88 & 0.005 & 0.423 \\
B Developed, Low Intensity & 70 & 0.008 & 0.532 \\
A Developed, Open Space & 39 & 0.014 & 0.562 \\
A Emergent Herbaceous Wetlands & 78 & 0.010 & 0.749 \\
B Developed, Open Space & 61 & 0.003 & 0.195 \\
A Deciduous Forest & 30 & 0.022 & 0.660 \\
B Deciduous Forest & 55 & 0.000 & 0.022 \\
B Emergent Herbaceous Wetlands & 78 & 0.000 & 0.031 \\
B Evergreen Forest & 60 & 0.000 & 0.024 \\
A Evergreen Forest & 36 & 0.004 & 0.130
\end{tabular}

$\mathrm{CN}($ Weighted $)=$ Total Product $\backslash$ Total Area $=.6679$

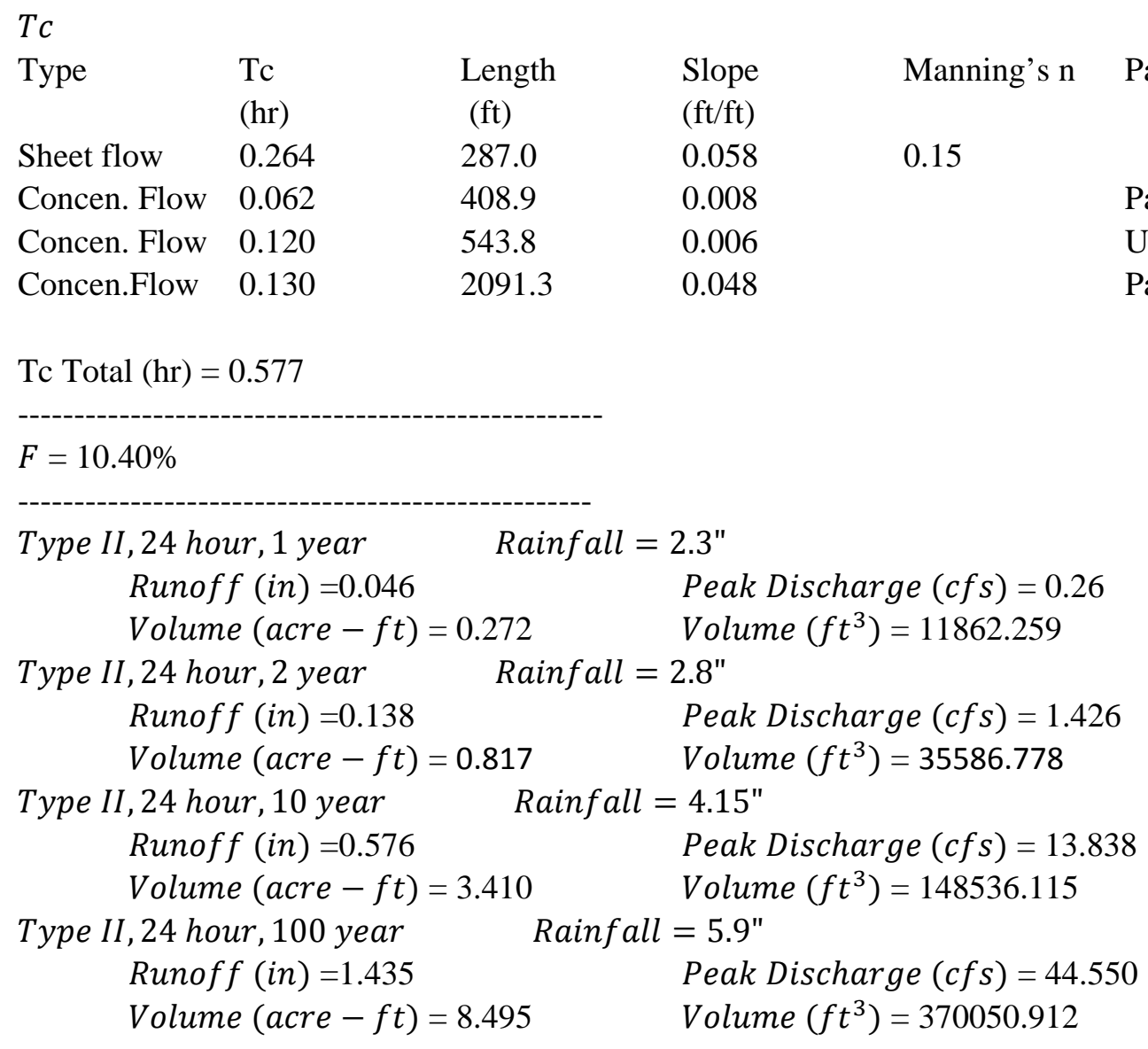




\section{Report for Basin 12B}

$\operatorname{Area}\left(m i^{2}\right)=0.393$

CN

HSG Land Use Description
A Landfill with 0-10\% impervious cover
A Upland deciduous forest
$\begin{array}{lll}32 & 0.003 & 0.089\end{array}$
A $26-50 \%$ Impervious cover with perennial grass
$49 \quad 0.006 \quad 0.289$
A Shrubland
$\begin{array}{lll}43 & 0.001 & 0.045\end{array}$
B Upland deciduous forest
$\begin{array}{lll}58 & 0.009 & 0.523\end{array}$
B Upland deciduous woodland
$\begin{array}{lll}55 & 0.012 & 0.668\end{array}$
A Upland deciduous woodland
$\begin{array}{lll}30 & 0.014 & 0.406\end{array}$
A Short grasses with sparse tree cover on upland
$\begin{array}{lll}43 & 0.007 & 0.313\end{array}$
B Short grasses with sparse tree cover on upland
$\begin{array}{lll}65 & 0.006 & 0.406\end{array}$
B 4-10\% Impervious cover with perennial grass
$\begin{array}{lll}54 & 0.000 & 0.019\end{array}$
A $\quad 4-10 \%$ Impervious cover with perennial grass
$\begin{array}{lll}32 & 0.000 & 0.011\end{array}$

\begin{tabular}{lrr}
$\mathrm{CN}$ & Area & $\mathrm{CN} \times \mathrm{A}$ \\
\hline 77 & 0.000 & 0.027
\end{tabular}

CN $($ Weighted $)=$ Total Product $\backslash$ Total Area $=47.3941$

$\begin{array}{llllll}\begin{array}{l}\text { Tc } \\ \text { Type }\end{array} & \begin{array}{l}\text { Tc } \\ (\mathrm{hr})\end{array} & \begin{array}{l}\text { Length } \\ (\mathrm{ft})\end{array} & \begin{array}{l}\text { Slope } \\ (\mathrm{ft} / \mathrm{ft})\end{array} & \text { Manning's n } & \text { Paved/Unpaved } \\ \text { Sheet flow } & 0.216 & 194.8 & 0.318 & 0.4 & \\ \text { Sheet flow } & 0.039 & 99.315 & 0.818 & 0.15 & \\ \text { Concen. flow } & 0.138 & 2946.4 & 0.136 & & \text { Unpaved }\end{array}$

Tc Total $(\mathrm{hr})=0.393$

$F=0 \%$

Type II, 24 hour, 1 year $\quad$ Rainfall $=2.3 "$

Runoff (in) $=0.001 \quad$ Peak Discharge $($ cfs $)=0.001$

Volume $($ acre $-f t)=0.004 \quad$ Volume $\left(f t^{3}\right)=160.301$

Type II, 24 hour, 2 year $\quad$ Rainfall $=2.8 "$

Runoff $($ in $)=0.029 \quad$ Peak Discharge $($ cfs $)=0.118$

Volume $($ acre $-f t)=0.107 \quad$ Volume $\left(f t^{3}\right)=4648.723$

Type II, 24 hour, 10 year $\quad$ Rainfall $=4.15 "$

Runoff $($ in $)=0.029 \quad$ Peak Discharge $($ cfs $)=4.307$

Volume $($ acre $-f t)=1.052 \quad$ Volume $\left(f t^{3}\right)=45846.029$

Type II, 24 hour, 100 year $\quad$ Rainfall $=5.9 "$

Runoff (in) $=0.916 \quad$ Peak Discharge $($ cfs $)=26.99$

Volume $($ acre $-f t)=3.371 \quad$ Volume $\left(f t^{3}\right)=146835.533$ 


\section{Report for Basin 13B}

$\operatorname{Area}\left(m i^{2}\right)=0.308$

CN

HSG Land Use Description

B Grassland with sparse tree layer

B Short grasses with sparse tree cover on upland

\begin{tabular}{lrl}
$\mathrm{CN}$ & Area & $\mathrm{CN} \times \mathrm{A}$ \\
\hline 61 & 0.018 & 1.079
\end{tabular}

B Upland deciduous woodland

$\begin{array}{lll}65 & 0.090 & 5.878\end{array}$

B Shrubland

$\begin{array}{lll}55 & 0.033 & 1.838\end{array}$

C Short grasses with sparse tree cover on upland

$\begin{array}{lll}65 & 0.011 & 0.741\end{array}$

B Upland deciduous forest

$\begin{array}{lll}76 & 0.001 & 0.090\end{array}$

B Sand and gravel pits with impervious cover

$\begin{array}{lll}58 & 0.011 & 0.661\end{array}$

A Short grasses with sparse tree cover on upland

$\begin{array}{lll}86 & 0.016 & 1.386\end{array}$

A Upland deciduous woodland

$\begin{array}{lll}43 & 0.052 & 2.215\end{array}$

A Upland deciduous forest

$\begin{array}{lll}30 & 0.019 & 0.566\end{array}$

B $\quad 4-10 \%$ Impervious cover with perennial grass

$\begin{array}{lll}32 & 0.008 & 0.264\end{array}$

A Shrubland

$\begin{array}{lll}56 & 0.024 & 1.321\end{array}$

B Open water

$\begin{array}{lll}43 & 0.012 & 0.524\end{array}$

B Wetland-open water (palustrine)

$\begin{array}{lll}100 & 0.001 & 0.079\end{array}$

B Buildings and pavement with 91-100\% impervious cover

$\begin{array}{lll}85 & 0.004 & 0.334\end{array}$

A Grassland with sparse tree layer

$\begin{array}{lll}89 & 0.002 & 0.210\end{array}$

$\begin{array}{lll}39 & 0.003 & 0.123\end{array}$

A Wetland-open water (palustrine)

$\begin{array}{lll}85 & 0.002 & 0.167\end{array}$

CN $($ Weighted $)=$ Total Product $\backslash$ Total Area $=56.6964$

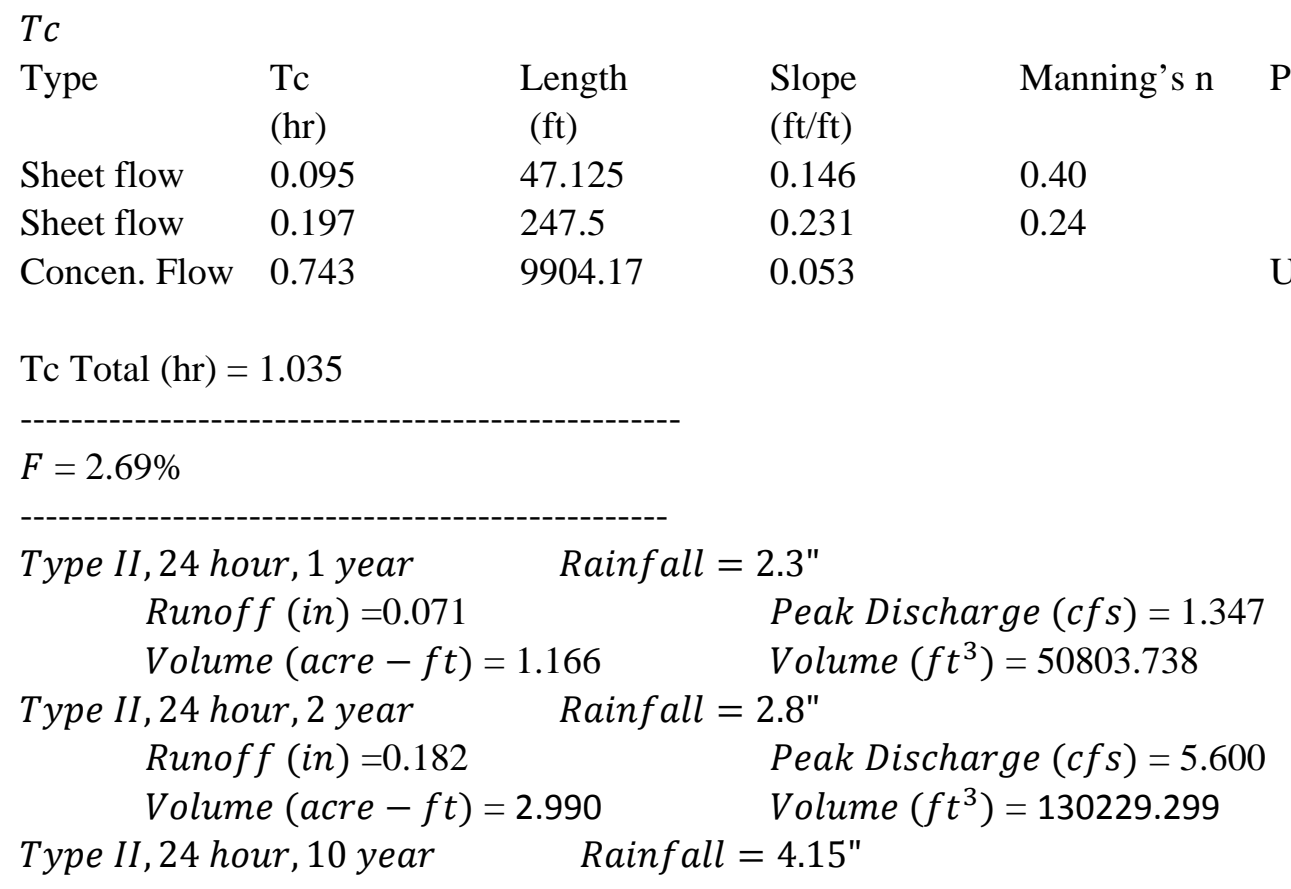




$$
\begin{array}{ll}
\text { Runoff }(\text { in })=0.670 & \text { Peak Discharge }(c f s)=38.978 \\
\text { Volume }(\text { acre }-f t)=11.006 & \text { Volume }\left(f t^{3}\right)=479415.552
\end{array}
$$

Type II, 24 hour, 100 year $\quad$ Rainfall $=5.9 "$

Runoff $($ in $)=1.592 \quad$ Peak Discharge $($ cfs $)=112.345$

Volume $($ acre $-f t)=26.151 \quad$ Volume $\left(f t^{3}\right)=4098900.749$ 
Report for Basin 14B

Area $\left(m i^{2}\right)=0.806$

CN

HSG Land Use Description

B Short grasses with sparse tree cover on upland

\begin{tabular}{lcc} 
CN & Area & CN $\times$ A \\
\hline 65 & 0.118 & 7.687 \\
43 & 0.178 & 7.653 \\
32 & 0.070 & 2.253 \\
34 & 0.013 & 0.430 \\
56 & 0.002 & 0.133 \\
58 & 0.008 & 0.482 \\
55 & 0.006 & 0.326 \\
65 & 0.016 & 1.028 \\
85 & 0.136 & 11.565 \\
30 & 0.012 & 0.356 \\
95 & 0.162 & 15.406 \\
43 & 0.023 & 1.003 \\
32 & 0.021 & 0.683 \\
58 & 0.003 & 0.161 \\
70 & 0.001 & 0.055 \\
88 & 0.004 & 0.313 \\
49 & 0.000 & 0.019 \\
78 & 0.001 & 0.093 \\
30 & 0.006 & 0.166 \\
85 & 0.006 & 0.471 \\
81 & 0.001 & 0.064 \\
36 & 0.000 & 0.014 \\
78 & 0.000 & 0.031 \\
69 & 0.004 & 0.273 \\
54 & 0.002 & 0.107
\end{tabular}

A Short grasses with sparse tree cover on upland

A Upland deciduous forest

A $\quad 4-10 \%$ Impervious cover with perennial grass

B 4-10\% Impervious cover with perennial grass

B Upland deciduous forest

B Upland deciduous woodland

B Shrubland

A Wetland-open water (palustrine)

A Upland deciduous woodland

A Permanently flooded littoral aquatic bed

A Shrubland

A Coniferous woodland

B Coniferous woodland

B Developed, low intensity

B Developed, medium intensity

A Hay/pasture

A Emergent herbaceous wetlands

A Deciduous forest

B Wetland-open water (palustrine)

A Developed, medium intensity

A Evergreen forest

B Emergent herbaceous wetlands

B Hay/pasture

A Developed, low intensity

$\mathrm{CN}($ Weighted $)=$ Total Product $\backslash$ Total Area $=63.9611$

Tc

Type

Tc

Length

Slope

Manning's n Paved/Unpaved

Sheet flow

(hr)

(ft)

$(\mathrm{ft} / \mathrm{ft})$

0.255

295

0.068

0.15

Concenc. Flow 1.693

12169.5

0.015

Unpaved

Tc Total $(\mathrm{hr})=1.948$

$F=37.47 \%$

Type II, 24 hour, 1 year

Runoff (in) $=0.202$

Volume $($ acre $-f t)=8.683$
Rainfall $=2.3 "$

Peak Discharge ( $c f s)=9.006$

Volume $\left(f t^{3}\right)=378244.838$ 
Type II, 24 hour, 2 year $\quad$ Rainfall $=2.8 "$

Runoff $($ in $)=0.383 \quad$ Peak Discharge $($ c $f s)=22.292$

Volume $($ acre $-f t)=16.464 \quad$ Volume $\left(f t^{3}\right)=717167.194$

Type II,24 hour, 10 year $\quad$ Rainfall $=4.15 "$

Runoff $($ in $)=1.056 \quad$ Peak Discharge $($ cfs $)=78.136$

Volume $($ acre $-f t)=45.394 \quad$ Volume $\left(f t^{3}\right)=1977359.155$

Type II, 24 hour, 100 year $\quad$ Rainfall $=5.9 "$

Runoff (in) $=2.189 \quad$ Peak Discharge $(c f s)=175.495$

Volume $($ acre $-f t)=94.098 \quad$ Volume $\left(f t^{3}\right)=4098900.749$ 


\begin{tabular}{lllll} 
Report for Basin 15B & & & \\
\hline Area $\left(\mathrm{mi}^{2}\right)=0.23$ & & & \\
CN & & & \\
HSG Land Use Description & CN & Area & CN × A \\
\cline { 2 - 4 } B & 93 & 0.015 & 1.363 \\
B Shement with 76-90 \% impervious cover & 65 & 0.121 & 7.858 \\
A Upland deciduous woodland & 30 & 0.011 & 0.316 \\
B 4-10\% Impervious cover with perennial grass & 54 & 0.001 & 0.049 \\
A 4-10\% Impervious cover with perennial grass & 32 & 0.000 & 0.015 \\
A Short grasses with sparse tree cover on upland & 43 & 0.017 & 0.748 \\
B Upland deciduous forest & 58 & 0.012 & 0.717 \\
B Upland deciduous woodland & 55 & 0.032 & 1.738 \\
A Upland deciduous forest & 32 & 0.004 & 0.117 \\
B Shrubland & 65 & 0.002 & 0.149 \\
A Pavement with 76-90\% impervious cover & 93 & 0.002 & 0.213 \\
B Buildings and pavement with 91-100\% & & & \\
& impervious cover & 99 & 0.022 & 2.176 \\
B Bioretention & 10 & 0.003 & 0.027 \\
A Shrubland & 43 & 0.000 & 0.020 \\
B 91-100\% Impervious cover & 88 & 0.004 & 0.363 \\
B Developed, open space & 61 & 0.007 & 0.419 \\
B Grassland with sparse tree layer & 61 & 0.001 & 0.084
\end{tabular}

$\mathrm{CN}($ Weighted $)=$ Total Product $\backslash$ Total Area $=64.3$

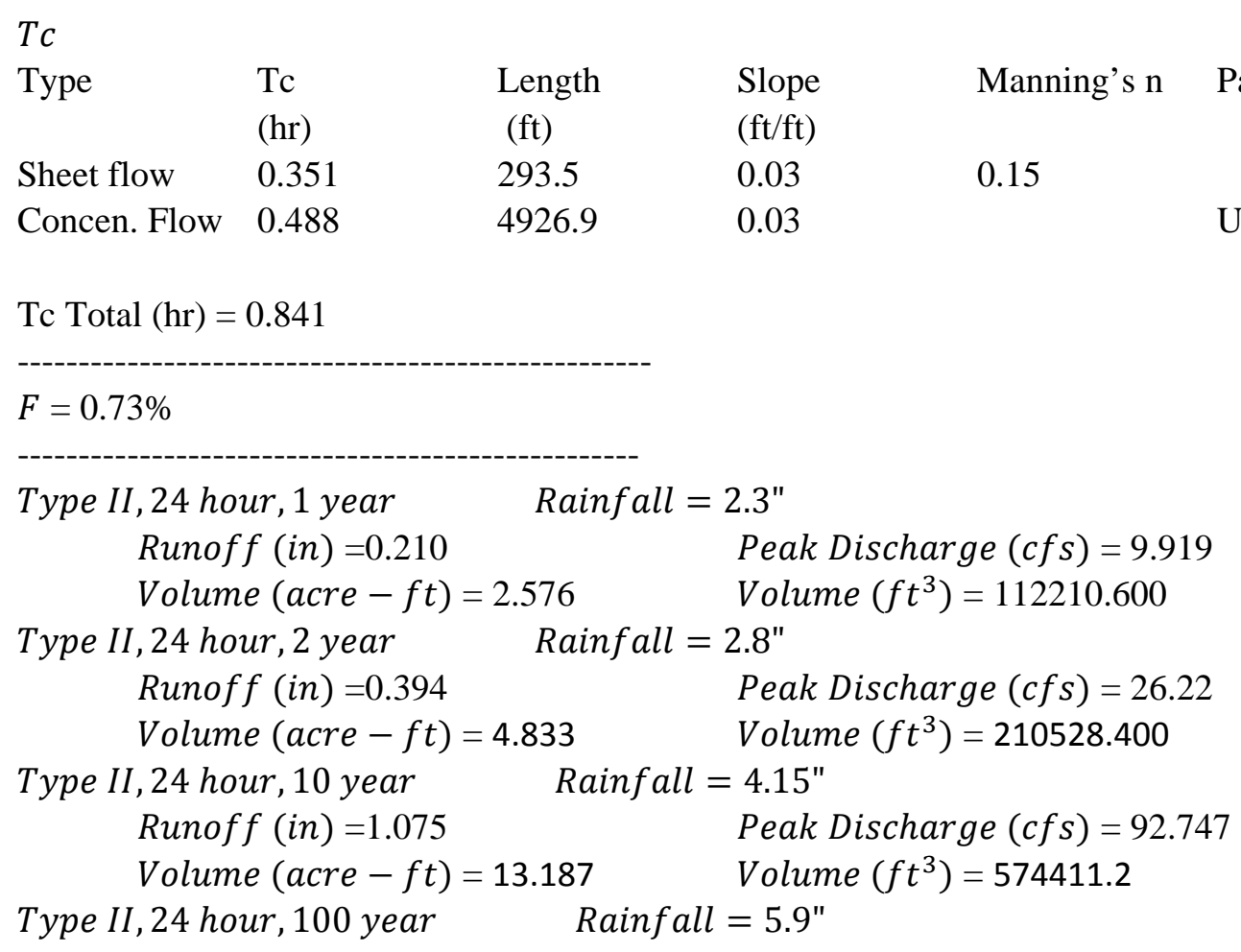


Runoff (in) $=2.218$

Volume $($ acre $-f t)=27.207$
Peak Discharge $(c f s)=206.317$

Volume $\left(f t^{3}\right)=1185157$ 


\section{Report for Basin 16B}

Area $\left(m i^{2}\right)=0.02$

$\mathrm{CN}$

HSG Land Use Description

B Buildings and pavement with 91-100\%

$\underline{\mathrm{CN}}$ Area $\mathrm{CN} \times \mathrm{A}$ impervious

$99 \quad 0.019 \quad 1.886$

B Short grasses with sparse tree cover on upland

$\begin{array}{lll}65 & 0.001 & 0.076\end{array}$

CN $($ Weighted $)=$ Total Product $\backslash$ Total Area $=97.07$

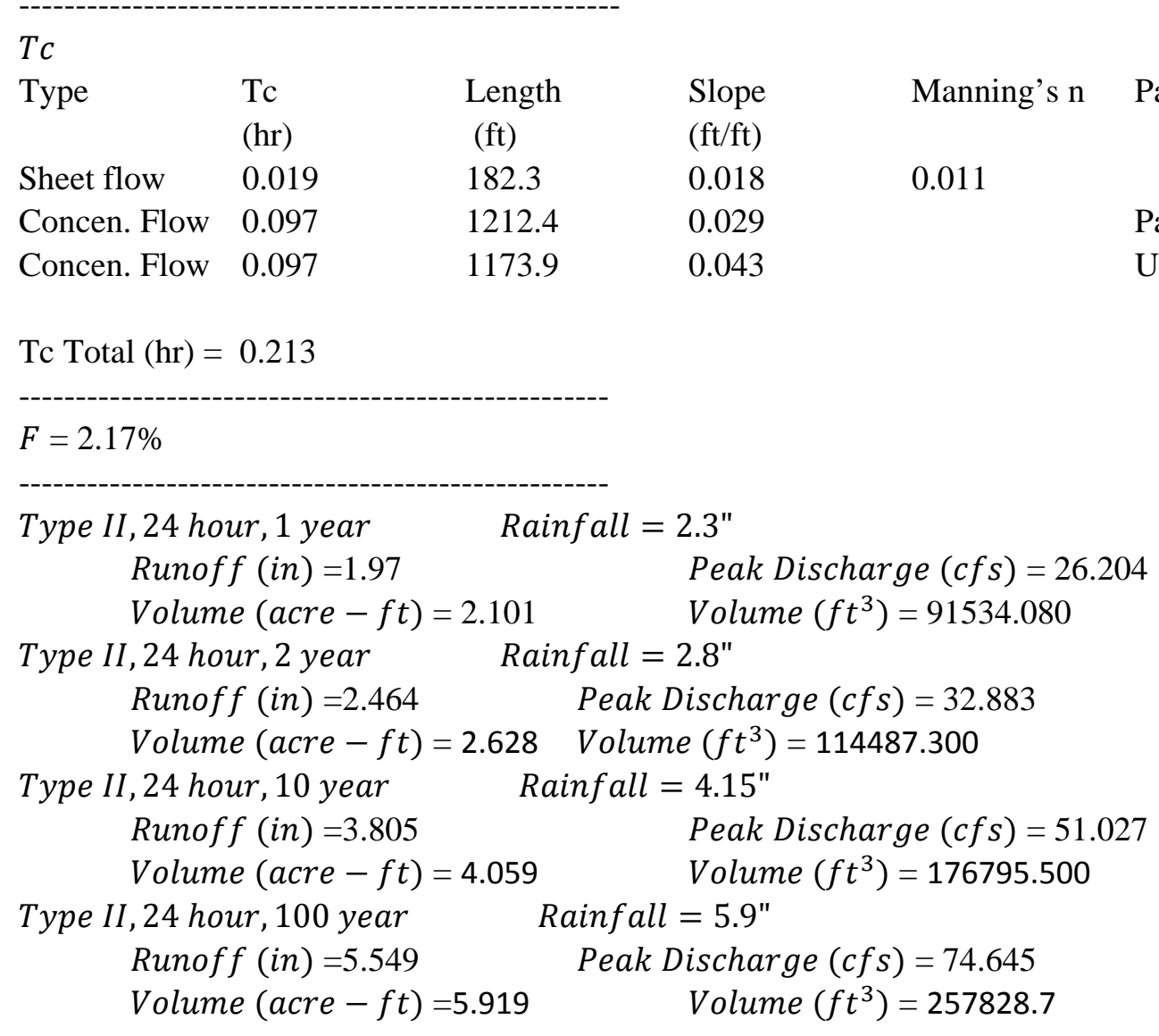


This page intentionally left blank 


\section{APPENDIX B:}

\section{FLOW AT SUBBASINS FOR STORM EVENTS USING THE TR-55 TABULAR HYDROGRAPH METHOD}

The flows for the required storm frequencies for each subbasin are represented here in 16 flow charts. $\mathrm{P}$ is the peak runoff in cubic feet per second (cfs), $\mathrm{T}$ is the time of peak in minutes, and $\mathrm{V}$ is the total volume of runoff in cubic feet $\left(\mathrm{ft}^{3}\right)$. 
This page intentionally left blank 


\section{Basin 1}

Flow vs. Time

PEAK: $27.16 \mathrm{cfs}$ TIME OF PEAK: $744 \mathrm{~min}$ VOLUME: $126635.95 \mathrm{ft}^{\wedge} 3$

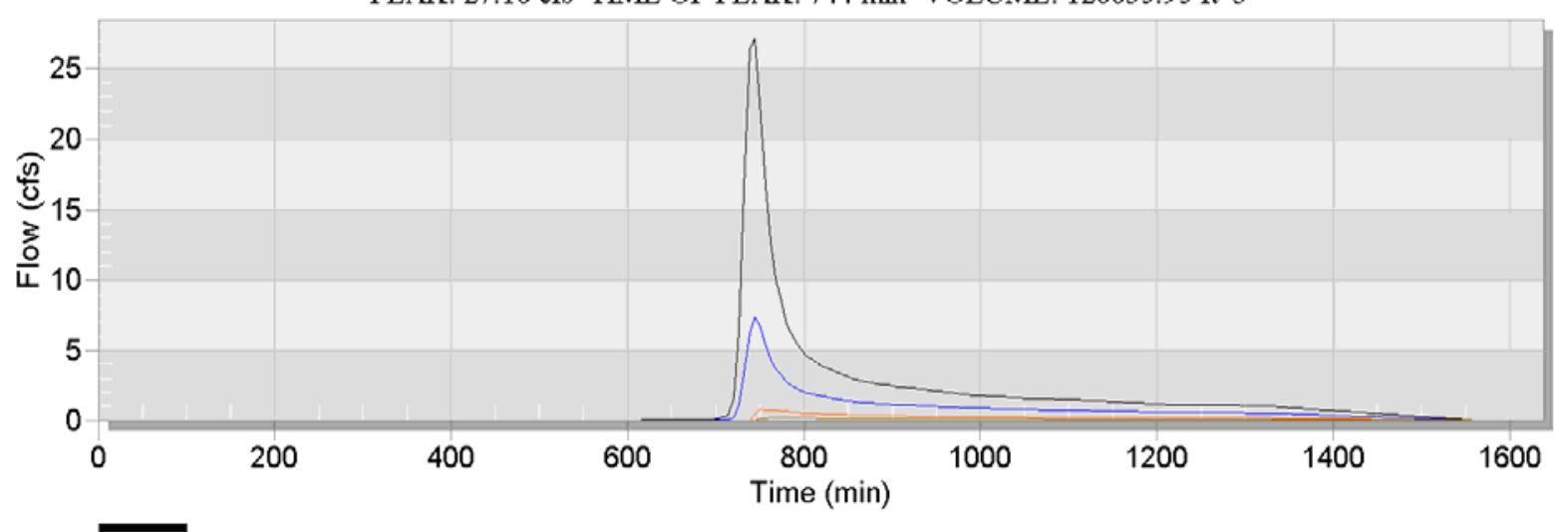

TR-55 Hydrograph 5.9" 100 yr, 1B, P:27.16, T:744, V:126636.0

TR-55 Hydrograph 4.15" 10 yг, 1B, P:7.37, T:744, V:48917.8

TR-55 Hydrograph 2.8" 2 yr, 1B, P:0.77, T:750, V:10973.9

TR-55 Hydrograph 2.3" 1 yr, 1B, P:0.19, T:768, V:3485.2

\section{Basin 2}

Flow vs. Time

PEAK: $57.44 \mathrm{cfs}$ TIME OF PEAK: $738 \mathrm{~min}$ VOLUME: $227214.98 \mathrm{ft}{ }^{\wedge} 3$

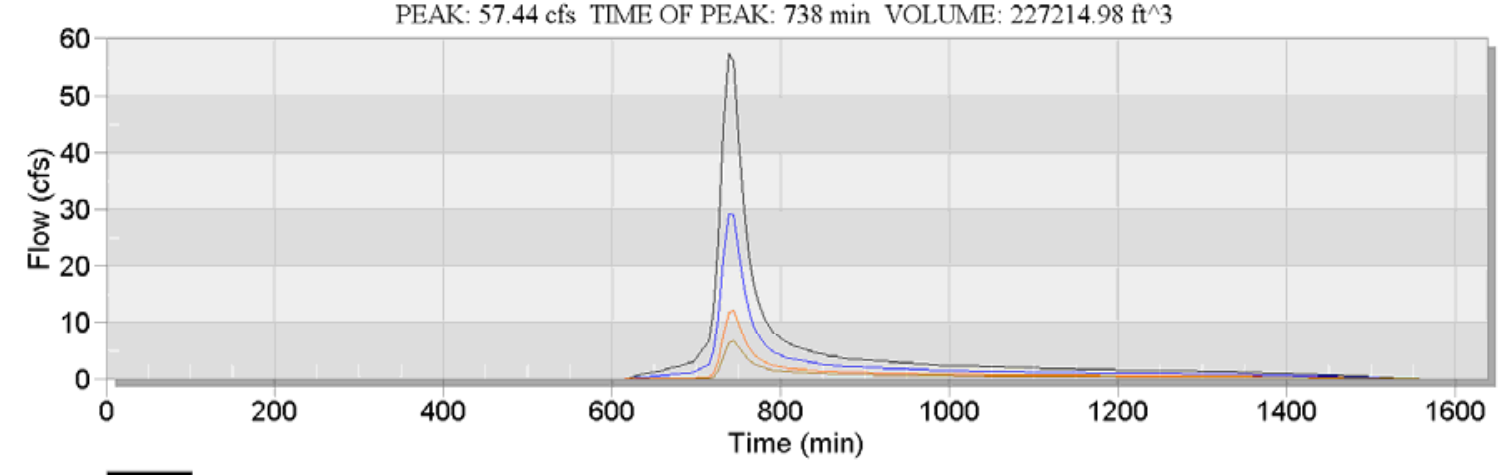

TR-55 Hydrograph 5.9" 100 yr, 2B, P:57.44, T:738, V:227215.0

TR-55 Hydrograph 4.15" 10 yr, 2B, P:29.29, T:738, V:123254.2

TR-55 Hydrograph 2.8" 2 yr, 2B, P:12.05, T:744, V:55200.5

TR-55 Hydrograph 2.3" 1 yr, 2B, P:6.67, T:744, V:34273.3

\section{Basin 3}


Flow vs. Time

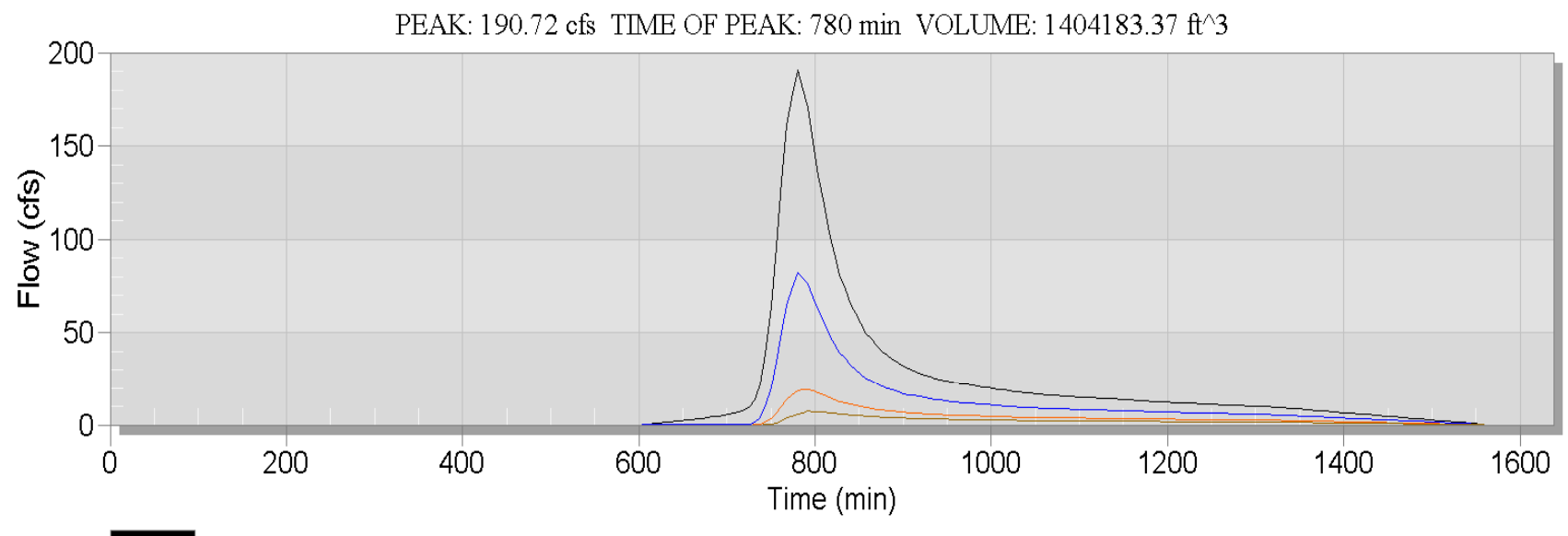

TR-55 Hydrograph 5.9" 100 yr, 3B, P:190.72, T:780, V:1404183.4

TR-55 Hydrograph 4.15" 10 yr, 3B, P:82.10, T:780, V:663373.1

TR-55 Hydrograph 2.8" 2 yr, 3B, P:19.38, T:792, V:225347.0

TR-55 Hydrograph 2.3" 1 yr, 3B, P:7.32, T:792, V:112316.8

\section{Basin 4}

Flow vs. Time

PEAK: $150.13 \mathrm{cfs}$ TIME OF PEAK: $792 \mathrm{~min}$ VOLUME: $1304450.10 \mathrm{ft}^{\wedge} 3$

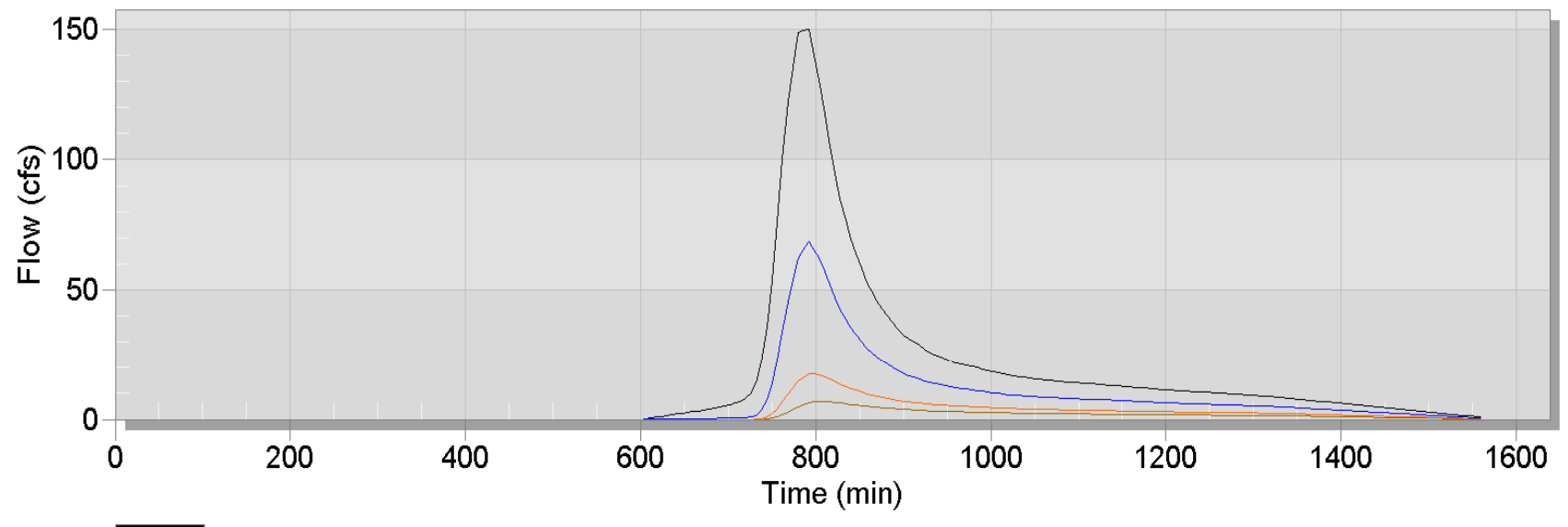

TR-55 Hydrograph 5.9" 100 yr, 4B, P:150.13, T:792, V:1304450.1

TR-55 Hydrograph 4.15" 10 yr, 4B, P:68.62, T:792, V:623633.5

TR-55 Hydrograph 2.8" 2 yr, 4B, P:17.60, T:792, V:219397.0

TR-55 Hydrograph 2.3" 1 yr, 4B, P:7.02, T:804, V:112707.9 


\section{Basin 5}

\section{Flow vs. Time}

PEAK: $207.22 \mathrm{cfs}$ TIME OF PEAK: 744 min VOLUME: $854697.26 \mathrm{ft}^{\wedge} 3$

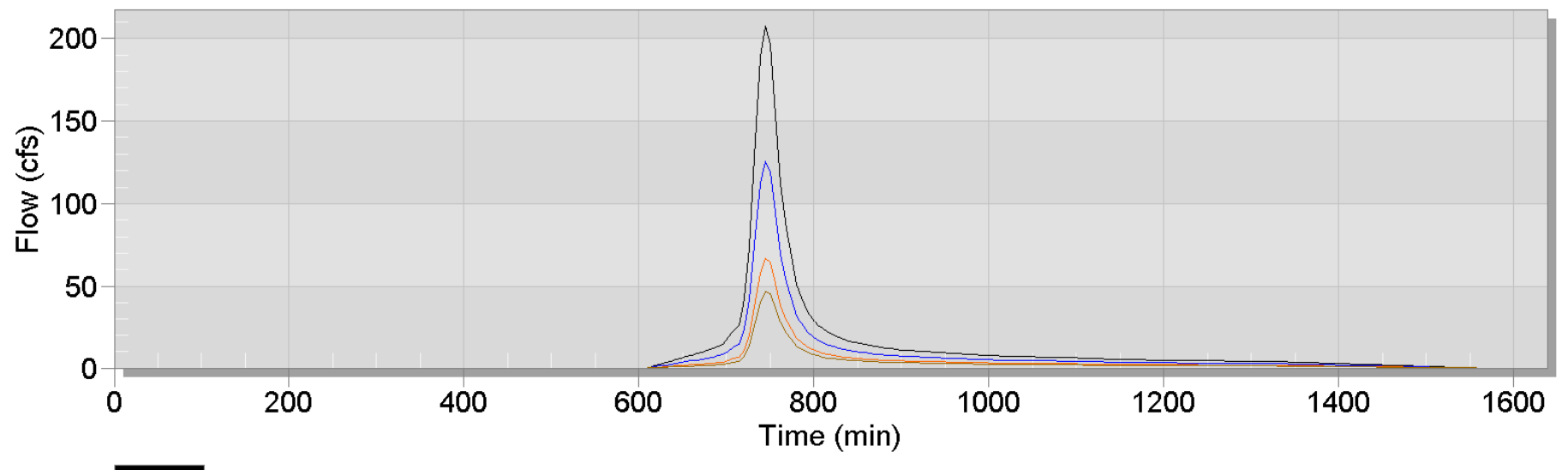

TR-55 Hydrograph 5.9" 100 yr, 5B, P:207.22, T:744, V:854697.3

TR-55 Hydrograph 4.15" 10 yr, 5B, P:125.32, T:744, V:529471.8

TR-55 Hydrograph 2.8" 2 yr, 5B, P:66.63, T:744, V:292983.4

TR-55 Hydrograph 2.3" 1 yr, 5B, P:46.84, T:744, V:211702.0

\section{Basin 6}

Flow vs. Time

PEAK: $46.57 \mathrm{cfs}$ TIME OF PEAK: 738 min VOLUME: $165191.89 \mathrm{ft}^{\wedge} 3$

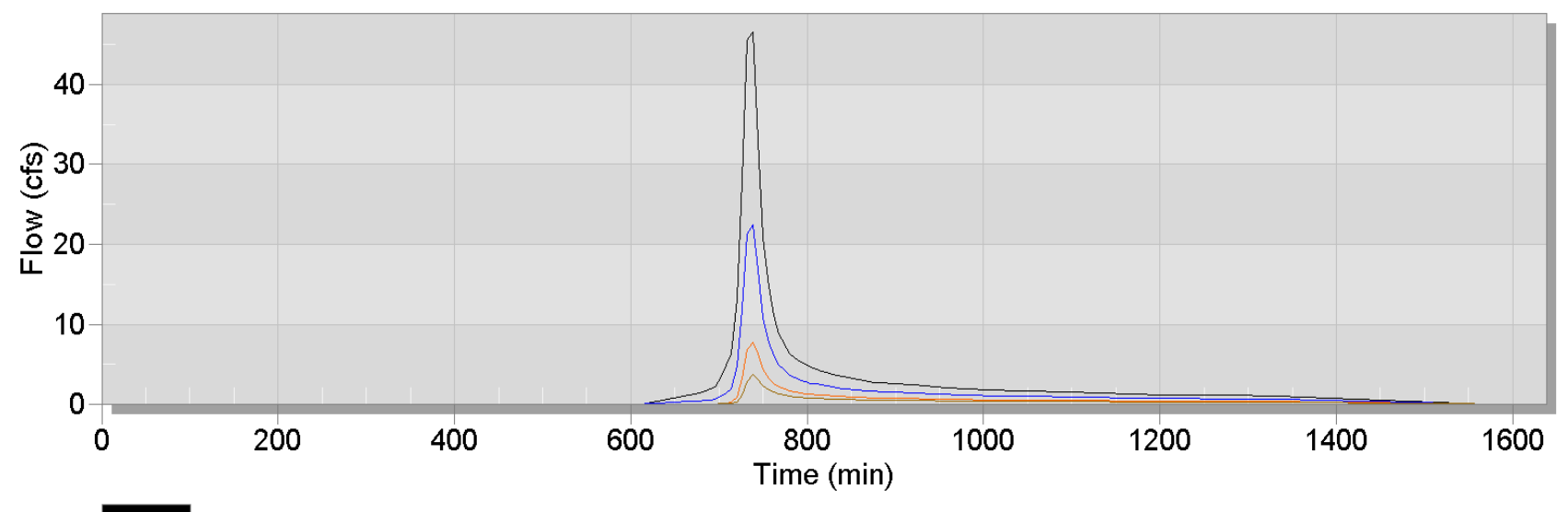

TR-55 Hydrograph 5.9" 100 yr, 6B, P:46.57, T:738, V:165191.9

TR-55 Hydrograph 4.15" 10 yr, 6B, P:22.51, T:738, V:84872.0

TR-55 Hydrograph 2.8" 2 yr, 6B, P:7.77, T:738, V:34441.5

TR-55 Hydrograph 2.3" 1 yr, 6B, P:3.62, T:738, V:19841.0 


\section{Basin 7}

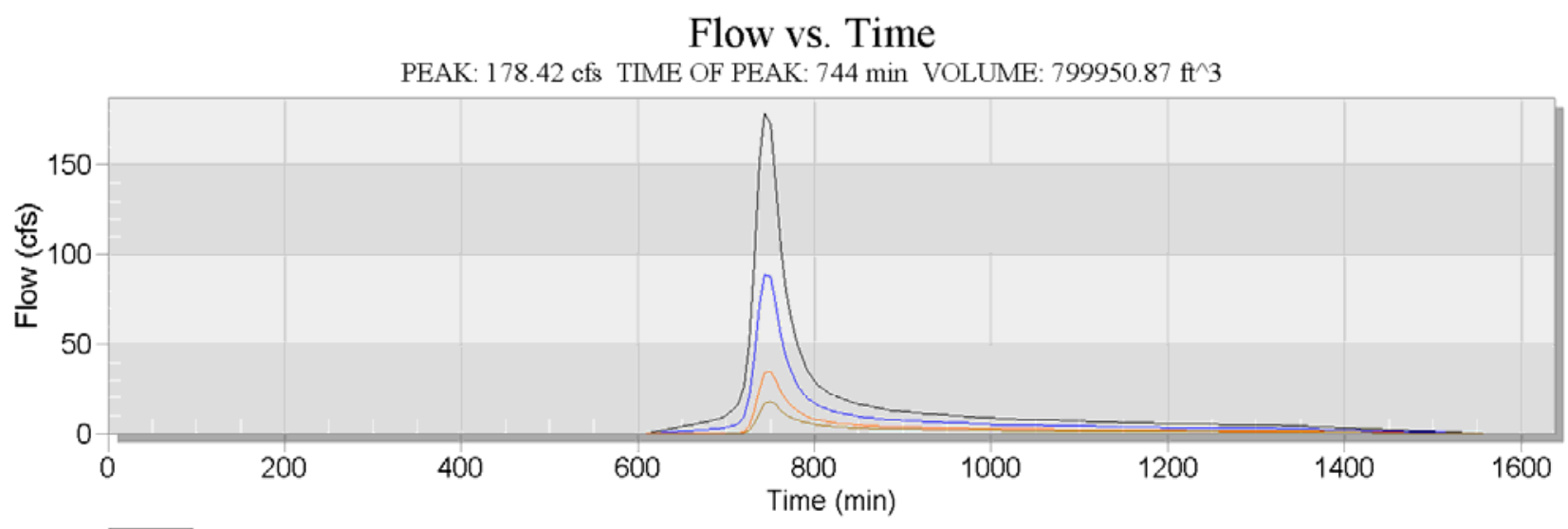

TR-55 Hydrograph 5.9" 100 yr, 7B, P:178.42, T:744, V:799950.9

TR-55 Hydrograph 4.15" 10 yr, 7B, P:89.01, T:744, V:425229.7

TR-55 Hydrograph 2.8" 2 yr, 7B, P:34.93, T:750, V:184010.0

TR-55 Hydrograph 2.3" 1 yr, 7B, P:17.76, T:750, V:110921.2

\section{Basin 8}

Flow vs. Time

PEAK: $109.97 \mathrm{cfs}$ TIME OF PEAK: 762 min VOLUME: $704356.63 \mathrm{ft}^{\wedge} 3$

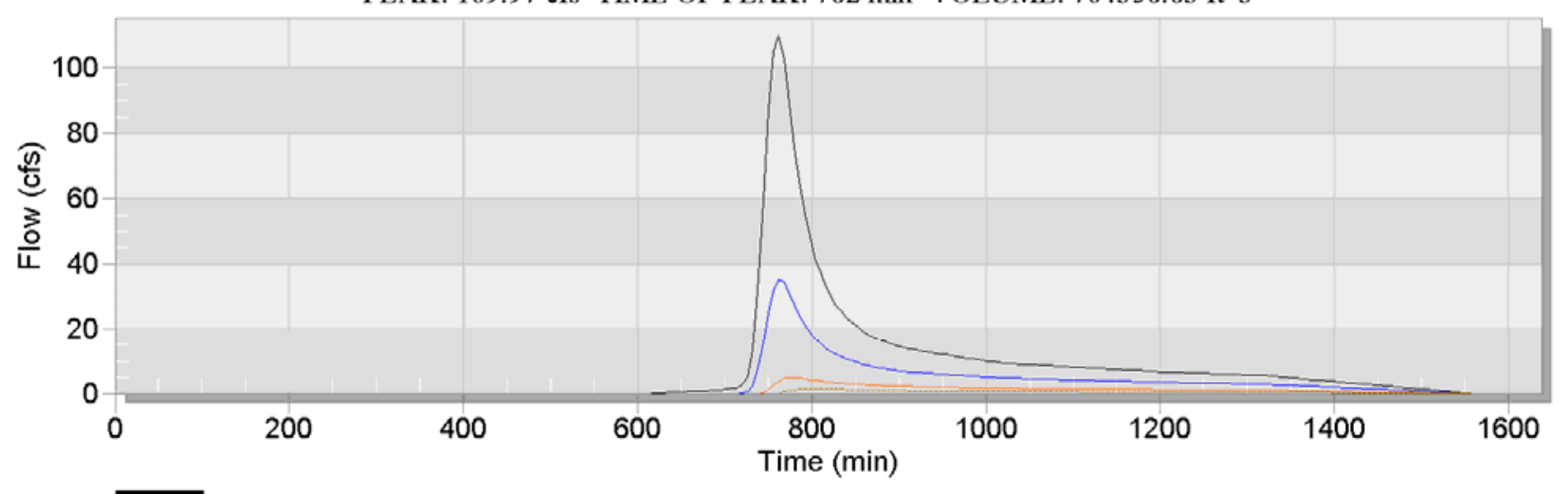

TR-55 Hydrograph 5.9" 100 yr, 8B, P:109.97, T:762, V:704356.6

TR-55 Hydrograph 4.15" 10 yr, 8B, P:34.95, T:762, V:289609.9

TR-55 Hydrograph 2.8" 2 yr, 8B, P:4.81, T:780, V:73935.4

TR-55 Hydrograph 2.3" 1 yr, 8B, P:1.38, T:792, V:28097.1 


\section{Basin 9}

Flow vs. Time

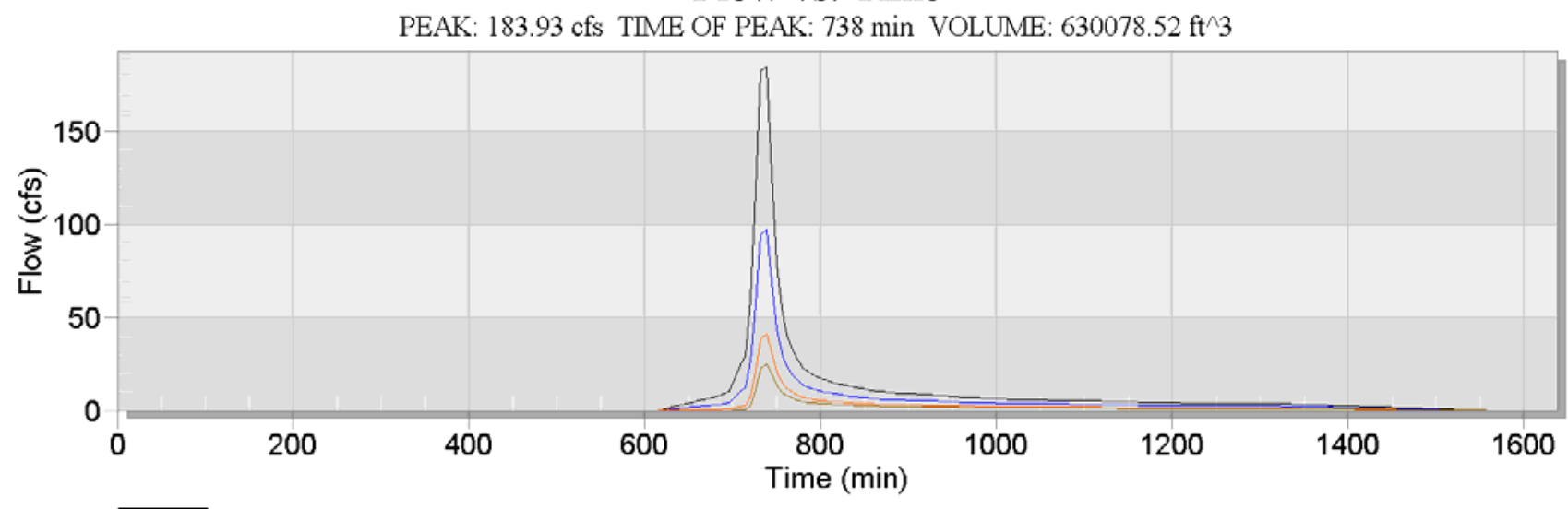

TR-55 Hydrograph 5.9" 100 yr, 9B, P:183.93, T:738, V:630078.5

TR-55 Hydrograph 4.15" 10 yr, 9B, P:97.15, T:738, V:347830.6

TR-55 Hydrograph 2.8" 2 yr, 9B, P:41.55, T:738, V:160410.1

TR-55 Hydrograph 2.3" 1 yr, 9B, P:24.85, T:738, V:102319.3

\section{Basin 11}

Flow vs. Time

PEAK: $66.46 \mathrm{cfs}$ TIME OF PEAK: $756 \mathrm{~min}$ VOLUME: $366664.55 \mathrm{ft} 3$

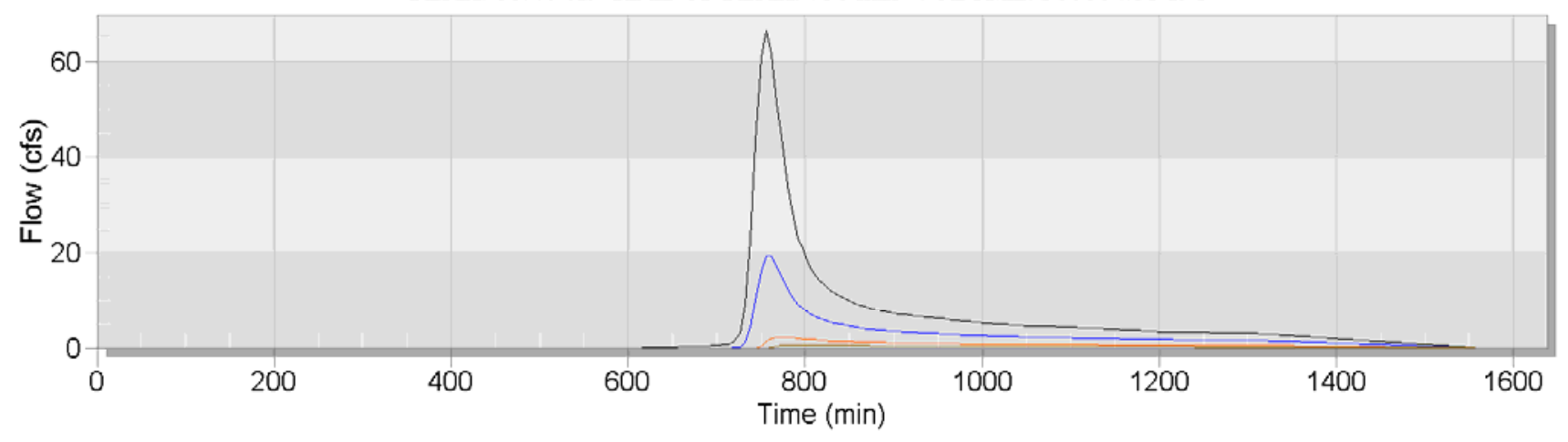

TR-55 Hydrograph 5.9" 100 yr, 11B, P:66.46, T:756, V:366664.5

TR-55 Hydrograph 4.15" 10 yr, 11B, P:19.39, T:762, V:145832.2

TR-55 Hydrograph 2.8" 2 yr, 11B, P:2.26, T:780, V:34680.1

TR-55 Hydrograph 2.3" 1 yr, 11B, P:0.63, T:792, V:12143.6 


\section{Basin 12}

Flow vs. Time

PEAK: $25.60 \mathrm{cfs}$ TIME OF PEAK: $744 \mathrm{~min}$ VOLUME: $147866.64 \mathrm{ft}^{\wedge} 3$

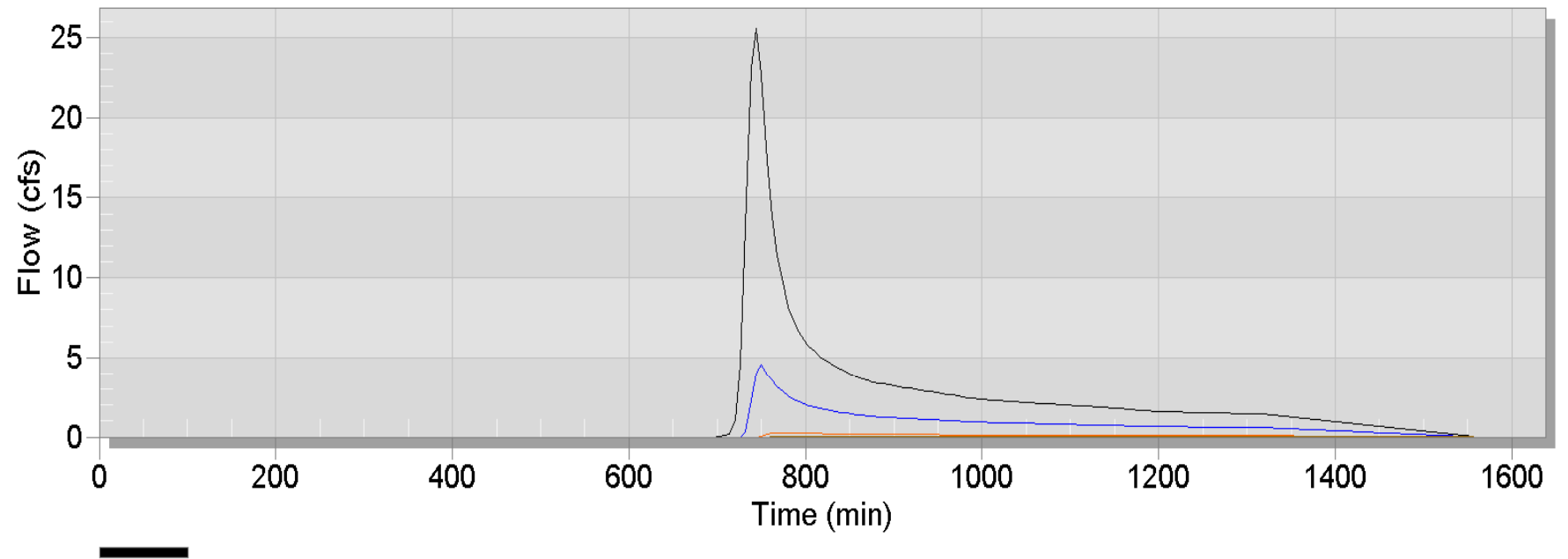

TR-55 Hydrograph 5.9" 100 yr, 12B, P:25.60, T:744, V:147866.6

TR-55 Hydrograph 4.15" 10 yr, 12B, P:4.59, T:750, V:45804.3

TR-55 Hydrograph 2.8" 2 yr, 12B, P:0.26, T:780, V:5177.6

TR-55 Hydrograph 2.3" 1 yr, 12B, P:0.01, T:780, V:115.3 


\section{Basin 13}

Flow vs. Time

PEAK: $145.98 \mathrm{cfs}$ TIME OF PEAK: 780 min VOLUME: $1126549.12 \mathrm{ft} \wedge 3$

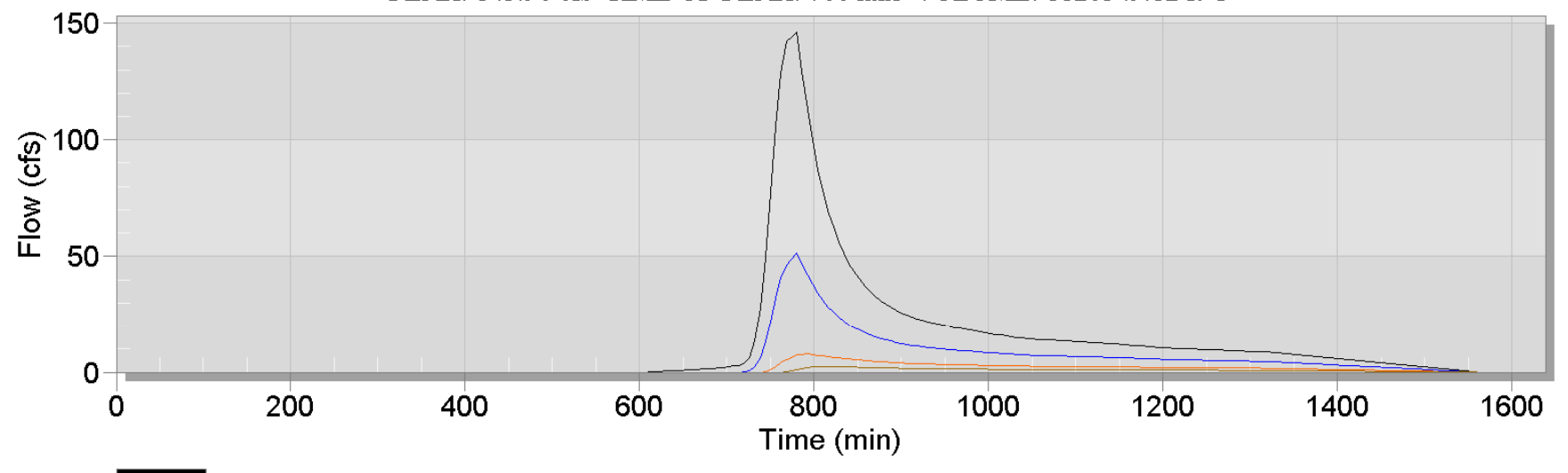

TR-55 Hydrograph 5.9" 100 yr, 13B, P:145.98, T:780, V:1126549.1

TR-55 Hydrograph 4.15" 10 yr, 13B, P:51.48, T:780, V:472506.3

TR-55 Hydrograph 2.8" 2 yr, 13B, P:7.80, T:792, V:125818.2

TR-55 Hydrograph 2.3" 1 yr, 13B, P:2.37, T:816, V:49728.8

\section{Basin 14}

Flow vs. Time

PEAK: $351.99 \mathrm{cfs}$ TIME OF PEAK: $804 \mathrm{~min}$ VOLUME: $4015210.61 \mathrm{ft} \mathrm{f}^{3} 3$

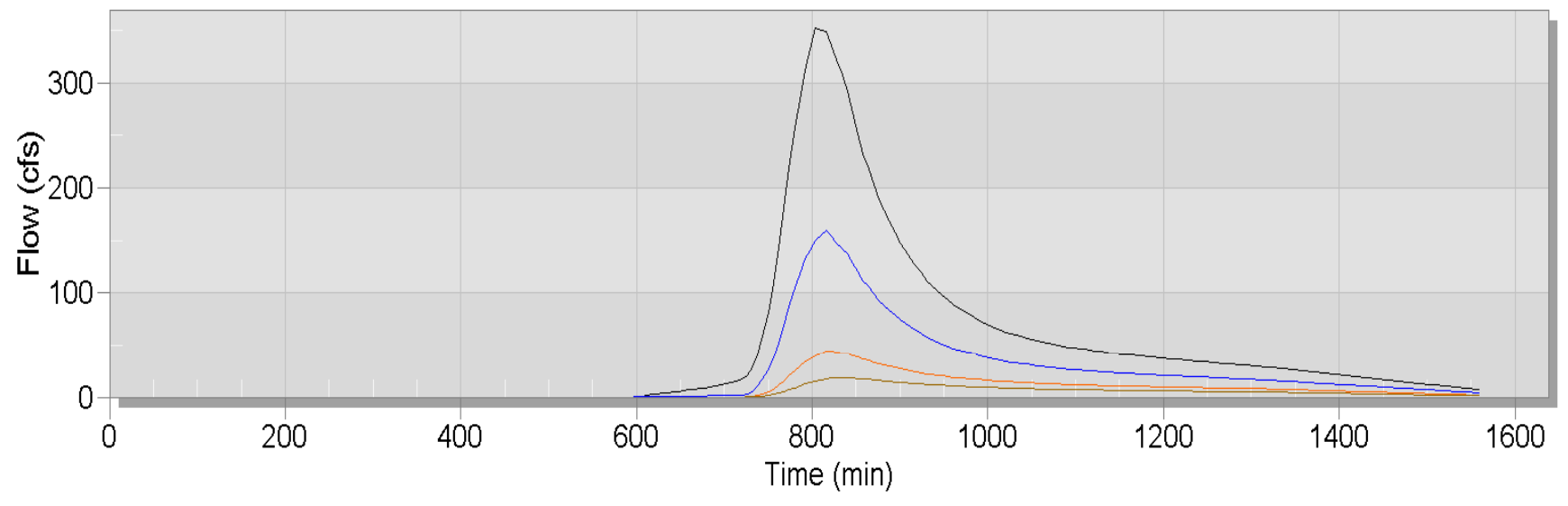

TR-55 Hydrograph 5.9" 100 yr, 14B, P:351.99, T:804, V:4015210.6

TR-55 Hydrograph 4.15" 10 yr, 14B, P:160.10, T:816, V:1934686.2

TR-55 Hydrograph 2.8" 2 yr, 14B, P:44.28, T:816, V:691979.8

TR-55 Hydrograph 2.3" 1 yr, 14B, P:18.62, T:840, V:360725.2 


\section{Basin 15}

Flow vs. Time

PEAK: $175.51 \mathrm{cfs}$ TIME OF PEAK: $768 \mathrm{~min}$ VOLUME: $1115812.20 \mathrm{ft}^{\wedge} 3$

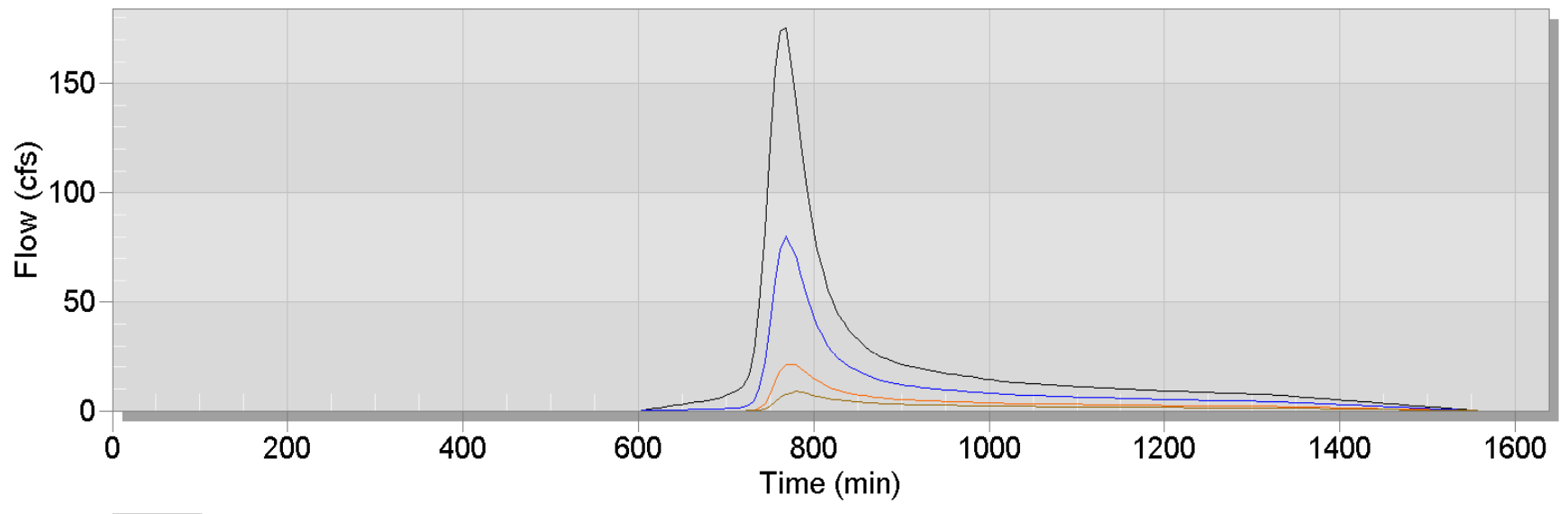

TR-55 Hydrograph 5.9" 100 yr, 15B, P:175.51, T:768, V:1115812.2

TR-55 Hydrograph 4.15" 10 yr, 15B, P:80.18, T:768, V:541620.1

TR-55 Hydrograph 2.8" 2 yr, 15B, P:21.22, T:780, V:196675.4

TR-55 Hydrograph 2.3" 1 yr, 15B, P:8.84, T:780, V:103785.9

\section{Basin 16}

\section{Flow vs. Time}

PEAK: $71.98 \mathrm{cfs}$ TIME OF PEAK: 738 min VOLUME: $251237.20 \mathrm{ft} ` 3$

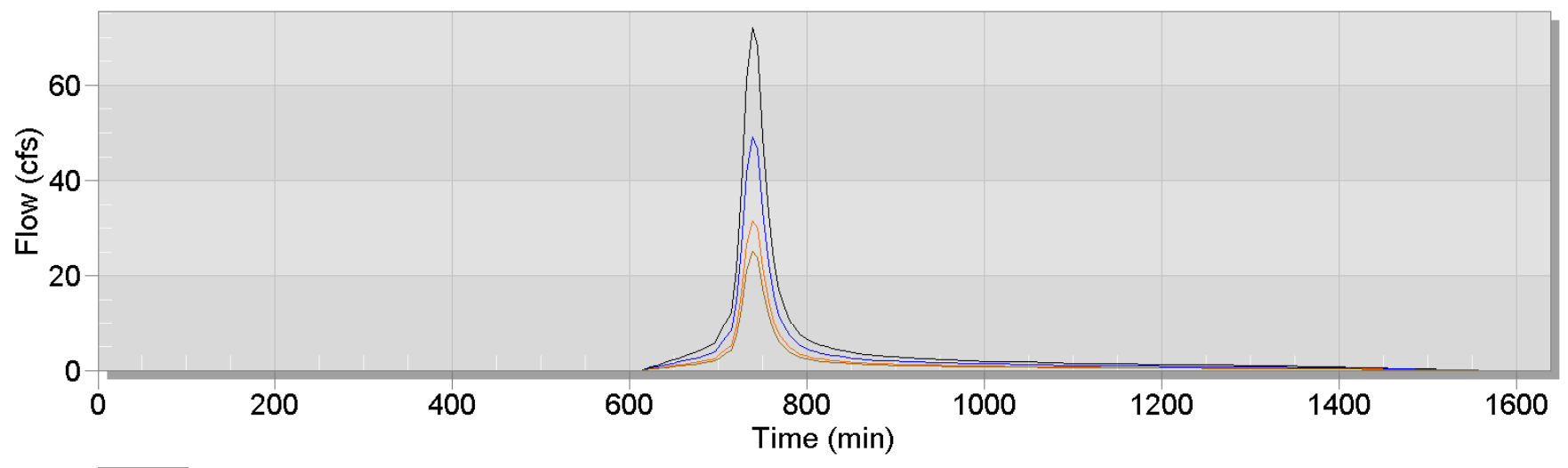

TR-55 Hydrograph 5.9" 100 yr, 16B, P:71.98, T:738, V:251237.2

TR-55 Hydrograph 4.15" 10 yr, 16B, P:49.15, T:738, V:172310.8

TR-55 Hydrograph 2.8" 2 yr, 16B, P:31.62, T:738, V:111638.4

TR-55 Hydrograph 2.3" 1 yr, 16B, P:25.16, T:738, V:89281.0 



\section{Argonne}

\section{Environmental Science Division}

Argonne National Laboratory

9700 South Cass Avenue, Bldg. 240

Argonne, IL 60439-4847

www.anl.gov

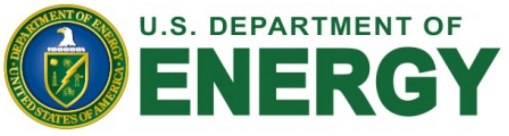

Argonne National Laboratory is a U.S. Department of Energy laboratory managed by UChicago Argonne, LLC 